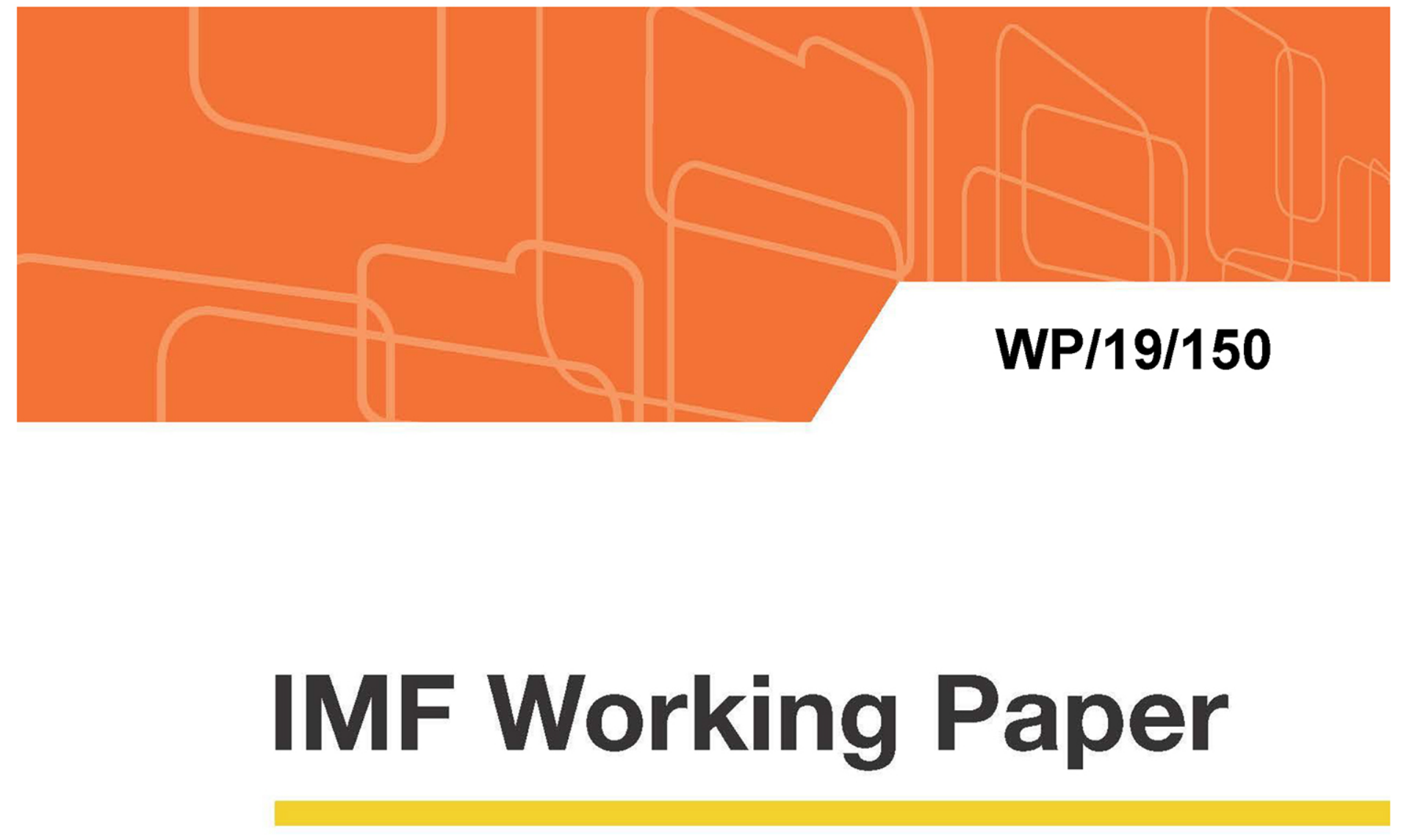

\title{
International Fiscal-financial Spillovers: \\ The Effect of Fiscal Shocks on Cross-border Bank Lending
}

by Sangyup Choi, Davide Furceri, and Chansik Yoon

IMF Working Papers describe research in progress by the author(s) and are published to elicit comments and to encourage debate. The views expressed in IMF Working Papers are those of the author(s) and do not necessarily represent the views of the IMF, its Executive Board, or IMF management.

I N T E R N A T I O N A L M O N E T A R Y F U N D 


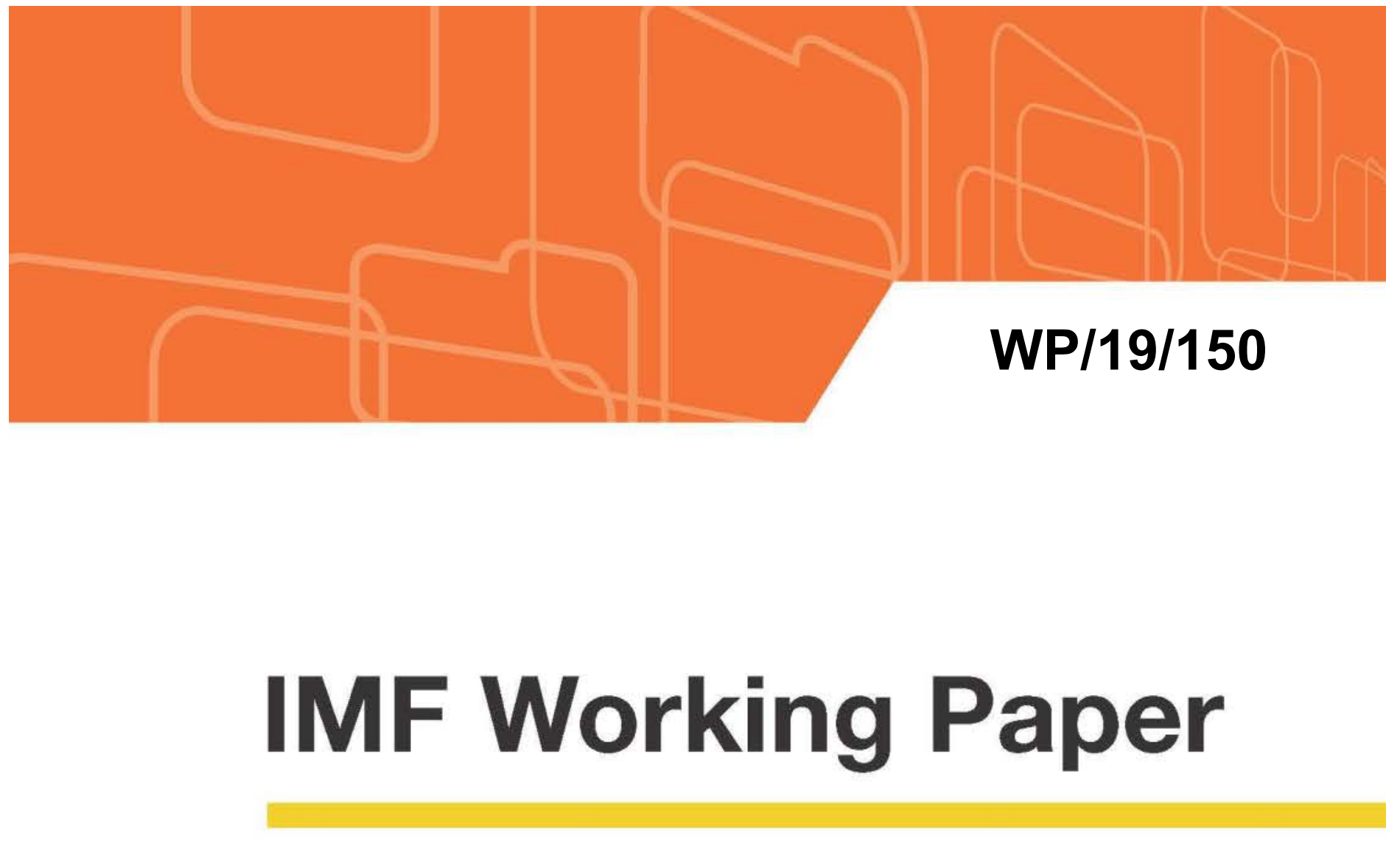

\section{International Fiscal-financial Spillovers: \\ The Effect of Fiscal Shocks on Cross-border Bank Lending}

by Sangyup Choi, Davide Furceri, and Chansik Yoon

IMF Working Papers describe research in progress by the author(s) and are published to elicit comments and to encourage debate. The views expressed in IMF Working Papers are those of the author(s) and do not necessarily represent the views of the IMF, its Executive Board, or IMF management.

I N T E R N A T I O N A L M O NETAR Y F U N D 


\title{
IMF Working Paper
}

\section{Research Department \\ International Fiscal-financial Spillovers: The Effect of Fiscal Shocks on Cross-border Bank Lending *}

\author{
Prepared by Sangyup Choi, Davide Furceri, and Chansik Yoon
}

Authorized for distribution by Chris Papageorgiou

July 2019

IMF Working Papers describe research in progress by the author(s) and are published to elicit comments and to encourage debate. The views expressed in IMF Working Papers are those of the author(s) and do not necessarily represent the views of the IMF, its Executive Board, or IMF management.

\begin{abstract}
This paper sheds new light on the degree of international fiscal-financial spillovers by investigating the effect of domestic fiscal policies on cross-border bank lending. By estimating the dynamic response of U.S. cross-border bank lending towards the 45 recipient countries to exogenous domestic fiscal shocks (both measured by spending and revenue) between 1990Q1 and 2012Q4, we find that expansionary domestic fiscal shocks lead to a statistically significant increase in cross-border bank lending. The magnitude of the effect is also economically significant: the effect of 1 percent of GDP increase (decrease) in spending (revenue) is comparable to an exogenous decline in the federal funds rate. We also find that fiscal shocks tend to have larger effects during periods of recessions than expansions in the source country, and that the adverse effect of a fiscal consolidation is larger than the positive effect of the same size of a fiscal expansion. In contrast, we do not find systematic and statistically significant differences in the spillover effects across recipient countries depending on their exchange rate regime, although capital controls seem to play some moderating role. The extension of the analysis to a panel of 16 small open economies confirms the finding from the U.S. economy.
\end{abstract}

JEL Classification Numbers: E62, F21, F32, F42.

Keywords: Fiscal-financial spillovers, Cross-border banking flows, Local projections, Nonlinear effects, Trilemma.

Author’s E-Mail Address: sangyupchoi@gmail.com, dfurceri@imf.org, chansik.yoon93@gmail.com

\footnotetext{
* We are thankful to Jaebin Ahn, Andrea Caggese, Şebnem Kalemli-Özcan, Enisse Kharroubi, Jinil Kim, Soyoung Kim, Jong-Wha Lee, Kwanho Shin, Livio Stracca, and the seminar participants at the Korean Macroeconomics Research Group, Korea University, the Bank of Korea, the 3rd IEFS-EAER Conference in Seoul and the 6th ECB-CBRT Conference in Izmir. The views expressed are those of the authors and do not necessarily represent those of the IMF or its policy. Any remaining errors are the authors' sole responsibility.
} 


\section{Contents}

I. INTRODUCTION

II. RELATED LITERATURE $\underline{4}$

III. DATA 9

A. Data on Cross-border Banking Flows ___

B. Data on Fiscal Shocks

IV. EMPIRICAL METHODOLOGY

A. General Framework

B. Analysis of U.S. Fiscal Shocks __ 17

V. RESULTS

A. Analysis of Cross-border Spillovers for U.S. Fiscal Shocks

B. Analysis of Cross-border Fiscal-Financial Spillovers in Small Open Economies ___ 29

VI. CONCLUSIONS _ _ 31

\section{REFERENCES}

\section{TABLES}

Table 1. List of countries in the international panel analysis $\underline{38}$

Table 2. Total cross-border claims and liabilities as a share of GDP __

Table 3. Baseline estimation results from a dynamic framework __

Table 4. Summary of exogenous spending shocks in 16 OECD countries: 1990-2010__ 42

\section{FIGURES}

Figure 1. Total U.S. cross-border bank claims: raw stock vs. exchange rate-adjusted stock $\underline{43}$ Figure 2. Exchange rate-adjusted U.S. cross-border bank claims to individual countries __ 44 Figure 3. Time series of exogenous fiscal shocks in the U.S. $\underline{45}$ Figure 4. Estimated effect of a U.S. expansionary fiscal policy shock on cross-border bank lending $\underline{45}$

Figure 5. Transmission channel of U.S. fiscal shocks $\underline{46}$

Figure 6. Estimated effect of a U.S. expansionary fiscal policy shock on cross-border bank lending after controlling for monetary policy shocks $\underline{47}$

Figure 7. Forecast variance error decomposition of cross-border bank lending _ $\quad 47$ Figure 8. Estimated effect of a U.S. expansionary fiscal policy shock (1 percent of GDP) on cross-border bank net lending $\underline{48}$

Figure 9. NBER recession dates and the weight on a recession regime $\underline{48}$ Figure 10. Estimated effect of a U.S. expansionary fiscal policy shock on cross-border bank lending: expansions vs. recessions

Figure 11. Estimated effect of a U.S. expansionary fiscal policy shock on cross-border bank lending: expansionary vs. contractionary shocks Figure 12. Estimated effect of a U.S. expansionary fiscal policy shock on cross-border bank lending: pegged vs. non-pegged recipients $\underline{50}$ Figure 13. Estimated effect of a U.S. expansionary fiscal policy shock on cross-border bank lending: financially open vs. closed recipient countries 
Figure 14. Distribution of fiscal policy shock as a share of GDP in 16 OECD countries from 1990 and 2010

Figure 15. Estimated effect of expansionary spending shock on cross-border bank lending using 16 OECD countries

\section{APPENDIX}

Table A1. Data availability on cross-border flows in the BIS International Banking Statistics

Figure B1. Estimated effect of a U.S. expansionary fiscal policy shock on cross-border bank lending: controlling for other macroeconomic variables $\underline{53}$ Figure B.2. Estimated effect of a U.S. expansionary fiscal policy shock on cross-border bank lending: using eight lags instead $\underline{53}$ Figure B.3. Estimated effect of a U.S. expansionary fiscal policy shock on cross-border bank lending: using Driscoll-Kraay standard error $\underline{54}$ Figure B.4. Estimated effect of a U.S. expansionary fiscal policy shock on cross-border bank lending: controlling for bilateral imports $\underline{54}$ Figure B.5. Estimated effect of a U.S. expansionary fiscal policy shock on cross-border bank lending $\underline{55}$ Figure B.6. Estimated effect of a U.S. expansionary fiscal policy shock on cross-border bank lending after controlling for monetary policy shocks and VIX shocks $\underline{55}$ Figure B.7. Estimated effect of a U.S. expansionary fiscal policy shock on cross-border bank borrowing $\underline{56}$ Figure B.8. Estimated effect of a U.S. expansionary fiscal policy shock on cross-border bank lending: advanced vs. emerging market recipient countries $\underline{56}$ Figure B.9. Estimated effect of a U.S. expansionary spending shock on cross-border bank lending using 16 OECD countries: alternative fixed effects $\underline{57}$ Figure B.10. Estimated effect of expansionary fiscal policy shock on cross-border bank lending using 16 OECD countries: expansions vs. recessions $\underline{57}$ Figure B.11. Estimated effect of expansionary fiscal policy shock on cross-border bank lending using 16 OECD countries: expansionary vs. contractionary shocks Figure B.12. Estimated effect of expansionary fiscal policy shock on cross-border bank lending using 16 OECD countries: pegged vs. non-pegged $\underline{58}$ Figure B.12. Estimated effect of expansionary fiscal policy shock on cross-border bank lending using 16 OECD countries: open vs. closed recipient countries $\underline{59}$ 


\section{INTRODUCTION}

The binding zero-lower-bound in advanced economies since the Global Financial Crisis (GFC) has rekindled a stream of research on the role of fiscal policy as a key stabilization tool and the potential engine of growth of the domestic economy (Eggertsson, 2011; DeLong and Summers, 2012). The GFC has also reinvigorated the debate on the potential of fiscal austerity and fiscal stimulus especially in large and systemic economies such as the U.S. or the euro area to affect economic activity in other economies through cross-border spillovers. In particular, the policy debate has focused on the scope of countries with limited fiscal space to be supported by expansionary fiscal policy in countries with a fiscal and external surplus (Farhi and Werning, 2016; Blanchard et al., 2017; IMF, 2017).

Given this policy debate, it is not surprising that a large body of the empirical literature has analyzed the spillover effects of fiscal shocks, mostly through trade linkages (Auerbach and Gorodnichencko, 2013; IMF, 2013; Faccini et al., 2016; Goujard, 2017; IMF, 2017; Dabla-Norris et al., 2017). While these studies have shown evidence of sizeable fiscal spillovers through trade linkages, much less is known about the magnitude of fiscal spillovers through financial linkages and the international financial stability consequence of domestic fiscal policy. This paper contributes to the literature and the policy debates by providing the first analysis - to the best of our knowledge — of the effect of fiscal shocks on cross-border banking flows.

Among different types of international capital flows, we investigate the effect on crossborder banking flows of a domestic fiscal shock for two reasons. First, the bilateral nature of crossborder banking flow data we use permits a cleaner identification of international fiscal-financial spillovers since the bilateral structure allows to control for various demand factors in a recipient country, which may confound the interpretation of the empirical findings otherwise. ${ }^{1}$ Indeed, simply analyzing aggregate capital flows obtained from the balance of payments $(\mathrm{BoP})$ statistics does not allow to effectively control for common factors affecting capital flows, such as a global financial cycle (Rey, 2015). Second, while most previous studies focused on the effect of various shocks on net capital flows where financial flows are seen only as the counterpart to the current account, the rapid expansion of gross international asset and liability positions calls for a deeper understanding of the

\footnotetext{
${ }^{1}$ For example, despite the exogeneity of our identified fiscal shocks (military spending news) in a source country to its domestic economic conditions, they are not necessarily orthogonal to the condition of the rest of the world, which could affect loan demand from a recipient country simultaneously.
} 
spillovers through gross flows that better reflect the impact on national balance sheets (Forbes and Warnock, 2012; Broner et al., 2013; Bruno and Shin, 2015a). ${ }^{2}$

To the extent that cross-border banking flows have meaningful implications for economic and financial conditions in recipient countries, as suggested by the recent empirical studies (e.g., Cetorelli and Goldberg, 2011; Bruno and Shin, 2015a), identifying the effect of domestic fiscal shocks on cross-border bank lending can shed new light on the overall spillover effects of fiscal policy. From a theoretical point of view, however, the sign of the spillover effects is ambiguous a priori, especially once the response of the exchange rate and of the interest rate to a fiscal expansion is considered. For example, both standard Keynesian models, such as the Mundell-Fleming model, and RBC type of models typically predict an increase in domestic output shortly after a fiscal expansion. This leads to the expansion of cross-border bank lending through improved balance sheet conditions of the domestic banking system holding other variables constant. If a fiscal expansion is followed by the appreciation of domestic currencies as in the textbook models, cross-border bank lending is expected to further increase (Bruno and Shin, 2015a; Choi and Furceri, 2018). However, the extension of the standard model allowing for the deep habits (Ravn et al., 2012) or the spending reversals (Corsetti et al., 2012) can also generate real depreciation, which would have the opposite effect on cross-border bank lending.

In theory, monetary policy tightening has contrasting effects on cross-border bank lending depending on the channel considered. According to the bank lending channel, it reduces cross-border bank lending by increasing funding costs (Bruno and Shin, 2015b). In contrast, the portfolio channel predicts that changes in the stance of monetary policy prompt banks to rebalance loan portfolios, with monetary tightening causing reallocations toward relatively safer borrowers in foreign countries (Correa et al., 2017). Recently, Avdjiev and Hale (2018) find that the relationship between the U.S. federal funds rate and cross-border bank lending can be both positive or negative depending on whether an increase in the federal funds rate is an endogenous response to strong macroeconomic fundamentals or an exogenous shock to the monetary policy stance. Albrizio et al. (forthcoming) find that an exogenous increase in the fed funds rate reduces cross-border bak lending. Thus, shedding light on the sign and magnitude of fiscal spillovers through cross-border banking remains largely an empirical task.

\footnotetext{
${ }^{2}$ However, since a bulk of cross-border bank lending in our dataset consists of bank loans and deposits rather than a bank's holding of debt securities, our analysis remains silent about other types of financial linkages such as international bond flows with the increasing importance in shaping global liquidity recently.
} 
To test international fiscal-financial spillovers, this paper estimates the dynamic response of cross-border bank lending to exogenous domestic fiscal (spending and revenue) shocks. ${ }^{3}$ In particular, we apply the local projection method (Jordà, 2005) to the cross-border banking data from the Bank for International Settlements Locational Banking Statistics. The bilateral structure of this dataset allows us to control for various external and macroeconomic shocks affecting credit demand in a recipient country. Thus, our empirical strategy mitigates a common criticism that countries are often subject to global shocks at the same time. In addition, we borrow exogenous measures of fiscal shocks from various sources-Romer and Romer (2010) for revenue and Ramey and Zubairy (2018) for spending shocks in the U.S.; and Auerbach and Gorodnichencko (2012b) for spending shocks in other small open economies - to gauge the causal effect of fiscal shocks on cross-border bank lending.

Given the plenty of empirical evidence about the nonlinear effect of fiscal shocks on output (Perotti, 1999; Auerbach and Gorodnichencko, 2012; Caggiano et al., 2015), we further investigate whether the effect of fiscal shocks depends on the underlying economic regimes (good vs. bad times) or types of shocks (expansionary vs. contractionary). We also analyze whether certain types of a recipient country's characteristics (such as the exchange rate regime and the degree of capital account openness guided by the Mundellian trilemma) amplify or dampen the cross-border fiscal-financial spillovers, which bears significant policy implications.

The results of the paper can be summarized as follows:

- Expansionary fiscal shocks in a source economy lead to an economically and statistically significant increase in cross-border bank lending to other counties. Interestingly, the effects are larger for revenue than spending shocks. In the U.S., the effect of a one percent of GDP increase in government spending (tax cut) on cross-border bank lending is equivalent to that of an exogenous decrease in the federal funds rate by $25 \mathrm{bp}$ (100bp).

- When jointly estimated with exogenous U.S. monetary policy shocks and the VIX shocks (as a proxy for a global financial cycle), U.S. fiscal policy shocks still account for a non-

\footnotetext{
${ }^{3}$ In contrast, we do not directly measure cross-border fiscal multipliers through financial linkages - an analogy to measuring fiscal multipliers through trade linkages as in Auerbach and Gorodnichencko (2013) and Goujard (2017) - for the following reasons. First, we are mainly interested in the consequence of domestic fiscal policy on cross-border financial stability in the financially integrated world, thereby shedding new light on the link that was never analyzed before. Second, unlike trade linkages that enter directly to the demand component of GDP, financial linkages measured by the volume of cross-border banking flows are expected to affect output indirectly.
} 
negligible share of the variation in cross-border bank lending, especially in the short run. Our finding implies that U.S. domestic fiscal policy action is an independent and important source of the so-called "global financial cycle".

- Cross-border fiscal-financial spillovers are larger when a fiscal expansion in the source economy is undertaken during a period of slack. This larger effect is consistent with the evidence of larger fiscal multipliers in recessions. In addition, the adverse effect of fiscal consolidation on cross-border bank lending tends to be larger in absolute value than the positive effect of the same size of a fiscal expansion.

- We find some suggestive evidence that capital controls are effective in moderating capital inflows. In contrast, we find that the degree of fiscal-financial spillovers does not significantly depend on a recipient country's exchange rate regime, suggesting - as argued by Rey (2015) — that the exchange rate regime is mostly irrelevant for cross-border financial spillovers.

The remainder of the paper is organized as follows. Section II reviews the related literature. Section III describes the data on cross-border banking flows and exogenous measures of fiscal shocks. Section IV presents the empirical methodology. Section V provides an extensive analysis of international fiscal-financial spillovers, including various robustness tests and additional exercises. Section VI concludes.

\section{RELATED LITERATURE}

This paper contributes to three strands of literature. First, while a large body of earlier studies on fiscal policy transmission focused on the impact of a fiscal shock on the domestic economy (Blanchard and Perotti, 2002; Mountford and Uhlig, 2009; Romer and Romer, 2010; Auerbach and Gorodnichencko, 2012), ${ }^{4}$ a more recent stream of research has analyzed the international transmission of fiscal shocks. The recent literature also focused on the scope of countries with limited fiscal space to be supported by expansionary fiscal policies in countries with a fiscal and external surplus (Auerbach and Gorodnichencko, 2013; Blanchard et al., 2017; IMF, 2017). While these studies mostly focus on trade linkages as a channel of transmission, we analyze financial linkages using cross-border banking data, thereby shedding new light on a potential international transmission

\footnotetext{
${ }^{4}$ We do not intend to summarize a mounting literature regarding fiscal multipliers. See Ramey (2011) for a recent survey of the literature on fiscal multipliers.
} 
channel of fiscal shocks. Our finding suggests that financial linkages are an important transmission mechanism of domestic fiscal shocks, independent of trade linkages.

Second, our work is closely related to the so-called "twin deficit" literature. While textbook accounting identities predict that fiscal deficits should lead to current account deficits, the empirical evidence suggests widely different estimates, and there is even disagreement about the sign of the effect of a fiscal deficit on the current account balance. For example, Beetsma et al. (2008) find that a one percent GDP increase in public spending is followed by a decline in the trade balance by 0.5 percent of GDP. Similarly, Feyrer and Shambaugh (2012) find that a one percent increase in taxes as a share of GDP improves the U.S. current account by 0.5 percent of GDP. By contrast, Kim and Roubini (2008), find that expansionary U.S. fiscal shocks tend to improve current account and claim that "twin divergence" is a more suitable description of the historical data. More recently, Ilzetzki et al. (2013) and Kim (2015) find that the sign of the effect of a fiscal deficit on current account depends on structural characteristics, such as capital openness and exchange rate regimes. We find robust evidence of an increase in net foreign claims by the domestic banking sector after a fiscal expansion, suggesting that the response of banking flows to fiscal shocks contributes to the improvement in the current account following a domestic fiscal expansion. Moreover, we find that an increase in net foreign claims is largely driven by an increase in cross-border claims, while cross-border liabilities remain largely unchanged. In the analysis using current account data, such a decomposition is not directly possible. Although our results seem to provide support for the "twin divergence" found in the empirical studies, it is important to recognize that bank-related flows are only just one component of the total capital flows, and therefore we provide only a suggestive answer on the effect of fiscal shocks on the current account.

Lastly, our paper sheds new light on the growing literature on global banking and the stability of the international financial system. Between the early 1990s and the GFC, the global economy has witnessed a marked increase in cross-border banking flows, primarily driven by the expansion of global operations of banks through developing networks of physical branches and subsidiaries in foreign countries. These flows were also most severely affected by the GFC (Milesi-Ferretti and Tille, 2011; Broner et al., 2013) and might induce the instability of the domestic financial system independent of domestic conditions (Hahm et al., 2013; Baskaya et al., 2017). While recent studies have tried to examine the driving factors of these flows, they focused mostly on monetary and/or financial drivers (Cetorelli and Goldberg, 2011; Kalemli-Ozcan et al., 2013; Bruno and Shin, 2015a; Cerutti et al., 2017; Correa et al., 2017; Avdjiev and Hale, 2018; Choi and Furceri, 2018). Our empirical findings emphasize that fiscal policy innovations in large advanced economies are an 
independent driver of cross-border banking flows, thereby providing new insights on factors explaining the global financial cycle.

\section{DATA}

\section{A. Data on Cross-border Banking Flows}

We use data on cross-border claims from the Bank for International Settlements (BIS)' Locational Banking Statistics (LBS) to identify international finical-financial spillovers. This dataset provides a geographical breakdown of banks' counterparties and the information about the currency composition of their balance sheets. The LBS dataset captures outstanding claims and liabilities of internationally active banks located in reporting countries against counterparties residing in more than 200 countries. The data is compiled following the residency principle that is consistent with the BoP statistics. ${ }^{5}$ In this regard, the major advantage of the BIS LBS data, compared to the banking flows collected from the BoP statistics, is the detailed breakdown of the reported series by recipient countries. Banks record their positions on an unconsolidated basis, including intragroup positions between offices of the same banking group. Currently, banking offices located in 46 countries, including many offshore financial centers, report the LBS. The LBS dataset captures around 95 percent of all cross-border interbank business (Bank for International Settlement, 2017). The bulk of cross-border bank claims and liabilities takes a form of loans and deposits of the domestic banking sector vis-à-vis all counterparty sectors (including banks and non-banks, and the private and public sector).

Another main advantage of the BIS LBS is that the currency composition of cross-border claims and liabilities is available so that cross-border banking flows expressed in the USD are adjusted for movements in exchange rates. The adjustment for exchange rate movements turns out to be crucial in our setup because of both theoretical and empirical evidence on the effect of fiscal shocks on the exchange rate, which is, in turn, tightly related to the effect on cross-border bank lending. 6

\footnotetext{
${ }^{5}$ While the data is made public by the BIS at the aggregate level, the data on bilateral claims and liabilities between reporting (source) and counterparty (recipient) countries is available to reporting central banks.

${ }^{6}$ Adjusted changes in amounts outstanding are calculated, as an approximation for flows. In addition to exchange rate fluctuations, the quarterly flows in the locational datasets are corrected for breaks in the reporting population. In Table A.1, we summarize the data availability in the BIS International Banking Statistics by reproducing Table 1 in Avdjiev and Elod Takáts (2014). This summary highlights the available information for each statistic, together with their limitations.
} 
The availability of a currency breakdown enables the BIS to calculate break- and exchange rate- adjusted changes in amounts outstanding. Such adjusted changes approximate underlying flows during each quarter. The adjusted change is calculated by first converting U.S. dollar-equivalent amounts outstanding into their original currency using end-of-period exchange rates, then calculating the difference in amounts outstanding in the original currency, and finally converting the difference into a U.S. dollar-equivalent change using average period exchange rates (Bank for International Settlements, 2017). ${ }^{7}$ As the BIS LBS only report the exchange rate-adjusted flows, we construct the exchange rate-adjusted stock of the cross-border claims from a country $i$ to a country $j$ by adding the exchange rate-adjusted flows to the exchange rate-unadjusted claims - directly available from the BIS LBS - in the initial period. We construct the exchange rate-adjusted stock of the cross-border liabilities in the same manner.

The time-series coverage of LBS database varies significantly across countries. Some advanced economies such as the U.S. have reported these statistics since 1977, while some emerging market economies started reporting statistics only after the 2000s. Thanks to the extensive availability of cross-border banking flow data and well-identified exogenous fiscal shock data at a quarterly frequency, we begin with analyzing cross-border spillovers of fiscal shocks through the bank lending channel using the U.S. data from 1990Q1 to 2012Q4. We then move to the analysis of other 16 OECD countries using a semi-annual dataset to test whether our findings from the U.S. analysis can be generalized to other small open economies.

Throughout the analysis, we drop offshore financial countries from our sample using the IMF classification because their behaviors might differ substantially from the rest of the sample. In the analysis of small open economies - after dropping offshore financial centers and the U.S. - we focus on 16 OECD countries where the measure of exogenous fiscal shocks constructed by Auerbach and Gorodnichencko (2012) is available. Similarly, we are left with 49 recipient countries in the baseline analysis after dropping offshore financial centers. Following Choi and Furceri (2018), we further drop observations with the size of cross-border positions less than $\$ 5$ million, or with negative total outstanding claims. Dependent variables in the upper and lower one percentile of the distribution are

\footnotetext{
${ }^{7}$ Nevertheless, the adjustment practice by the BIS cannot eliminate the possibility of under- or overestimation of actual flows. Adjusted changes could still be affected by changes in valuations, writedowns, the underreporting of breaks, and differences between the exchange rate on the transaction date and the quarterly average exchange rate used for conversion (see Avdjiev and Hale, 2018 for further details).
} 
excluded from the sample to eliminate outliers. ${ }^{8}$ Table 1 lists the final sample of reporting countries and their counterparties used in the panel analysis of small open economies, together with their average status regarding the exchange rate regime and capital openness during the sample period. ${ }^{9} \mathrm{We}$ use these country-specific characteristics to investigate factors affecting the international fiscalfinancial spillovers.

We present the size of total cross-border claims and liabilities as a share of the GDP in 2010Q4 for the 17 reporting countries in Table 2 to provide a first look at the data. Table 2 demonstrates the dominance of advanced economies in shaping the cross-border banking system. When normalized to the size of domestic GDP, both cross-border claims and liabilities of emerging market economies are smaller than those of advanced economies almost by two orders of magnitude. For example, cross-border claims and liabilities in Mexico are only five and seven percent of the GDP, while they account for 640 and 380 percent of the GDP in the U.K. Such a large difference between advanced and emerging market economies is far greater than the difference in overall financial openness measured by the sum of total gross asset and liability positions as a share of the GDP (Obstfeld, 2012). The predominant role of European countries in the cross-border banking system is also apparent. European countries engage in cross-border banking much more heavily than the U.S. and other advanced economies relative to the size of the economies. While global banks operating in advanced economies have more cross-border claims than liabilities, this pattern is reversed in emerging market economies.

To provide a further look at the underlying dynamics, we plot aggregate cross-border claims of the U.S. in Figure 1. We show both exchange rate-unadjusted and adjusted claims to demonstrate the importance of accounting for the valuation effect. Although they share a similar time-series pattern for the case of the U.S. (the correlation of 0.75) given that a lion's share of cross-border bank lending is denominated in the USD, it is not the case for other countries. In the sample of 16 OECD countries, the correlation between the growth rate of cross-border claims using two measures is only about 0.5 , suggesting a non-negligible role of the valuation effect in these economies. Moreover, accounting for the valuation effect results in a more pronounced decline in cross-border bank lending from the U.S. during the GFC, suggesting that the appreciation of the USD during this period

\footnotetext{
${ }^{8}$ We confirm that our main findings are hardly affected by such data-cleaning procedures. For example, censoring the dependent variables at the one percentile of the distribution or including the all observations hardly changes the main findings qualitatively.

${ }^{9}$ For each country, we take the time-series average of each measure to summarize the overall characteristics during the sample period.
} 
partially offsets a larger decline in "real" cross-border bank lending originally denominated in the USD. ${ }^{10}$

We further illustrate the bilateral structure of the data by presenting examples of bilateral cross-border claims between the U.S. and other six countries in Figure 2. Although we do not reveal the identity of individual counterparty countries, Figure 2 shows some heterogeneity in the pattern of cross-border claims among different country pairs. The first four recipient countries are advanced economies, and the last two recipient countries are emerging market economies. First, the different scales of the y-axis in these graphs re-emphasizes the dominance of advanced economies in shaping these flows. Second, the pattern found in the lending towards emerging market economies is different from that in advanced economies. Third, even among advanced economies, the pattern of crossborder lending from the U.S. is quite heterogeneous, suggesting that a recipient country's characteristics could play an important role in shaping the cross-border fiscal-financial spillovers.

\section{B. Data on Fiscal Shocks}

We rely on existing measures of exogenous fiscal shocks to gauge the causal effect of fiscal shocks on cross-border banking flows. For the case of the U.S., we use both exogenous spending and revenue shocks based on a narrative approach, whereas we use only exogenous spending shocks based on the unpredictable component of government spending for the analysis of small open economies. Here, we discuss briefly how these measures are constructed and refer to the original papers for further details.

\section{Measures of exogenous U.S. fiscal shocks}

As a baseline measure of U.S. fiscal shocks, we use 'defense news' shocks constructed by Ramey and Zubairy (2018), which are exogenous to business cycles and unpredictable with ex-ante information held by agents (RZ shocks, henceforth). These shocks are based on a narrative approach, which exploits information from the press (Business Week, New York Times, and Washington Post).

Under the benchmark neoclassical model in which the key effect of government spending operates through the wealth effect, RZ shocks measure the expected present discounted value of

\footnotetext{
${ }^{10}$ Although the U.S. experienced a large valuation loss in its net international investment position as an aggregatesuggesting that accounting for the valuation effect mitigates the decline in its net foreign asset position-, it is largely driven by a sharp fall in the prices of risky assets that the U.S. held in other countries. When it comes to cross-border banking, the adjustment through the exchange rate is a dominant factor of the valuation effect.
} 
government spending changes due to foreign political events. The variable used as the shock is the nominal value divided by the one-quarter lag of nominal GDP. We use lagged GDP, as it is not affected by contemporaneous fiscal shocks. ${ }^{11}$ The advantages of using RZ shocks are twofold. First, data are available at the quarterly frequency for a very extensive time sample (from 1889 to 2015). Second, the use of fiscal "news" ensures that the shocks are identified well before the spending takes place (or before they materialize in the NIPA accounts). This helps reduce the risk of endogeneity problems in the VAR analysis related to the presence of "fiscal foresight"- that is, the possibility that lags between the planning and the actual implementation of fiscal policy lead to anticipation of spending shocks (see Leeper et al., 2013 and Forni and Gambetti, 2016).

As a robustness test of our findings, we also use tax shocks identified by Romer and Romer (2010), limiting ourselves to the exogenous ones (RR shocks, henceforth). Similar to RZ shocks, they are also based on a narrative approach. Romer and Romer (2010) make use of narrative records, such as budget documents and speeches, to identify the size, timing, the principal motivation for fiscal actions, and to separate out tax changes that were made based on attempts to respond to current economic situations from those that are exogenous to current economic conditions. Exogenous tax changes are those that are not motivated by the objective to influence short-run conditions-such as counteracting influences on the economy or paying for increases in government spending - but those motivated by long-run goals - such as a desire to restore long-run budgetary balance or to spur longrun growth through lower marginal rates - or by a shift in government ideology. RR shocks cover both expansion and consolidation episodes at a quarterly frequency from 1945 to 2007 . Throughout the paper, we reverse the sign of RR shocks so that an increase in this measure indicates a tax cut, to make it consistent with the expansionary nature of the baseline measure of RZ shocks. ${ }^{12}$ In both cases, shocks are normalized to the GDP so that the impulse response functions track the percentage changes in cross-border bank lending when there is a one percent increase of GDP in government spending or tax cut.

Figure 3 plots the time series of both measures of fiscal shocks as a share of the lagged GDP during our sample period (1990Q1-2012Q4). One should note that expansionary spending shocks are often associated with exogenous increases in tax. Since the size of fiscal multipliers depends on

\footnotetext{
${ }^{11}$ Empirical evidence also suggests that the impact of fiscal shocks on output is minor in the first three quarters after the shock (Romer and Romer, 2010).

12 While Romer and Romer (2010) considered the effect of exogenous increases in tax, we adjust the sign so that we consider an exogenous tax cut (or an increase in revenue). Thus, we measure the effect of expansionary fiscal shocks in both cases.
} 
whether government spending is deficit-financed or financed with distortionary taxes (Ramey, 2011), we also estimate the cross-border fiscal-financial spillovers by including both RZ and RR shocks simultaneously as a further robustness check.

\section{Exogenous fiscal shocks for OECD economies}

In the extension of our analysis to small open economies, we employ the spending shock data for 16 OECD countries constructed by Auerbach and Gorodnichenko (2012) using OECD's Outlook and Projections Database (AG shocks, henceforth). Ideally, one would like to use exogenous spending shocks based on a narrative approach — such as the dataset constructed by Guajardo et al. (2014) of 17 OECD countries - to be consistent with the narrative approach used in the U.S. analysis. ${ }^{13}$ However, this dataset is only available at an annual frequency, whereas our main focus on financial flows makes it difficult to identify a causal effect using annual data.

Auerbach and Gorodnichenko (2012) conduct a regression analysis for each country, regressing one-period forecast errors for government spending from the OECD projection database on country's key macroeconomic variables, such as output, government spending, the exchange rate, inflation, investment, and imports. By taking the residuals of this regression, they identify unanticipated fiscal shocks that are orthogonal (exogenous) to the country's contemporaneous macroeconomic conditions. These residuals are normalized by the nominal GDP of each country. AG shocks are constructed on a semiannual basis since the OECD's forecasts data are available at this frequency and are available from 1985 to $2010 .{ }^{14}$

\section{EMPIRICAL METHODOLOGY}

\section{A. General Framework}

We use Jordà (2005)'s local projection method to assess the dynamic effect of domestic fiscal shocks on cross-border bank lending. The local projection method has been advocated by Auerbach and Gorodnichencko (2012) and Ramey and Zubairy (2018) among others, as a flexible alternative to

\footnotetext{
${ }^{13}$ Recently, Miyamoto et al. (2017) also construct a military spending dataset for a large group of countries, similar to the data by Ramey and Zubairy (2018). However, this dataset does not control for anticipated changes explicitly as in Ramey and Zubairy (2018) and is available only at an annual frequency.

14 The OECD's forecasts for major macroeconomic variables such as GDP and government spending are prepared twice a year, June and December. Times series of the forecasts consistently start from 1984 for "old" members of the OECD including the U.S., and from mid-1990s for relatively new members (e.g., Poland).
} 
VAR specifications without imposing the pattern generated by structural VARs. ${ }^{15}$ Auerbach and Gorodnichencko (2012) further confirm that the response of output to their exogenous government spending shocks - the one we use for the analysis of small open economies - is very similar between structural VARs and local projections. Thus, we believe our findings using the local projection method can be comparable to those obtained using structural VARs in the previous literature. We adopt the local projection method over commonly used VAR models to construct an impulseresponse function in this paper for the following reasons. First, the exogenous shocks we borrowed from the literature are either constructed by a narrative approach (Romer and Romer, 2010 and Ramey and Zubairy, 2018) or already orthogonalized to the contemporaneous macroeconomic conditions by controlling for macroeconomic forecasts (Auerbach and Gorodnichencko, 2012). For this reason, we do not need to further identify fiscal shocks using restrictions in VAR models - $\mathrm{a}$ common approach in many empirical analyses (e.g., Blanchard and Perotti, 2002). Second, our estimation entails a large bilateral panel dataset with the constellation of the fixed effects, which makes a direct application of standard VAR models more difficult. Thus, the local projection method obviates the need to estimate the equations for dependent variables other than the variable of interest, thereby economizing on the number of estimated parameters significantly. Third, the local projection method is particularly suited to estimating nonlinearities (for example, how the effect of fiscal shocks differs during expansions and recessions), as its application is much more straightforward compared to complex non-linear structural VAR models, such as Markov-switching or threshold-VAR models. Moreover, it allows to incorporate directly various features of recipient economies, such as the exchange rate regime or capital account openness using the local projection method. Lastly, the error term in the following panel estimations is likely to be correlated across countries. This correlation would be difficult to address in the context of nonlinear VAR models, but it is easy to handle in a linear estimation by either clustering standard errors by time period or using Driscoll-Kraay standard errors (Driscoll and Kraay, 1998).

Despite the advantages mentioned above, the local projection method has some drawback compared to structural VARs. Most importantly, structural VARs allow for the dynamic endogenous response of various macroeconomic variables, such as the interest rate or the exchange rate to fiscal shocks, which can also affect the dynamics of cross-border banking flows. The local projection method adopted in this paper, however, does not allow for the full dynamic interaction among

\footnotetext{
${ }^{15}$ Under the maintained assumption that the structural VAR is correctly specified, the patterns should be the same.
} 
variables. We revisit this issue in the following section, by investigating the response of the key macroeconomic variables to the identified fiscal shocks.

The local projection method simply requires estimation of a series of regressions for each horizon $h$ for each variable. We first present the general framework in a panel context and then derive the simplified version for the U.S. analysis. Following Auerbach and Gorodnichencko (2012) and Ramey and Zubairy (2018), we run a series of regressions for different horizons, $h=, 1,2, \ldots, H$ as follows:

$$
y_{i, j, t+h}-y_{i, j, t-1}=\alpha_{i, j}^{h}+\alpha_{j, t}^{h}+\beta^{h} F_{s h o c k}{ }_{i, t}+\sum_{p=1}^{n} \gamma^{h} X_{i, j, t-p}+\varepsilon_{i, j, t+h}
$$

where $i$ and $j$ indicate the reporting ('source') and counterparty ('recipient') countries, respectively; $y_{i, j, t}$ is the log of cross-border lending from global banks located in a country $i$ to borrowers in countries $j$ in time $t$; $F$ shock $_{i, t}$ is a measure of exogenous fiscal shock in a country $i . X_{i, j, t}$ is a set of control variables including lags of the dependent variable $y_{i, j, t}$ and lags of the fiscal shocks; $\alpha_{i, j}^{h}$ is source-recipient country fixed effect and $\alpha_{j, t}^{h}$ is a recipient-time fixed effect. $\beta^{h}$ is the coefficient of interest. We gauge the dynamic effect of fiscal shocks on cross-border bank lending by tracing $\beta^{h}$ over $h$-horizons. ${ }^{16}$

Together with the exogenous nature of fiscal shocks, the bilateral structure of the LBS data achieves a clean identification of cross-border fiscal-financial spillovers, largely immune to endogeneity issues. In particular, the advantages of having a bilateral panel dataset are threefold. First, it mitigates concerns about reverse causality. While it is difficult to identify causal effects of country-specific shocks using aggregate capital flows, it is much more likely that domestic fiscal shocks in a country $i$ affect cross-border bank lending towards a particular country $j$ than the other way around. Second, the inclusion of the fixed effects $\alpha_{i, j}^{h}$ specific to a country pair of a source country $i$ and a recipient country $j$ allows us to control for any unobserved time-invariant characteristic between two countries, such as a set of gravity factors widely used in the trade literature. ${ }^{17}$ Third, the inclusion of recipient country-time fixed effects allows us to control for any macroeconomic shocks affecting recipient countries, including external and idiosyncratic recipient-

\footnotetext{
${ }^{16}$ We also include a linear time trend, but it hardly changes the estimation results.

${ }^{17}$ The inclusion of $\alpha_{i, j}^{h}$ is more flexible than controlling for any set of common time-invariant regressors, as those commonly used in the Gravity model of international finance and controls simultaneously for any time-invariant characteristics specific to a country $i$ and a country $j$, respectively.
} 
specific shocks as well as the indirect impact of fiscal expansion through other recipient countries. The recipient country-time fixed effects largely control for an autocorrelation issue, although we account for this issue explicitly when computing standard errors. It also maximizes the sample coverage of our analysis because some recipient countries do not necessarily have data on control variables.

\section{B. Analysis of U.S. Fiscal Shocks}

In this section, we analyze the effect of domestic fiscal shocks on U.S. cross-border bank lending because of the significance of the U.S. in shaping the global economy and its wider data coverage compared to other advanced economies. We estimate the following model of the U.S. economy, which can be considered as a dynamic version of Feyrer and Shambaugh (2012) who study the effect of exogenous U.S. fiscal shocks — identified by Romer and Romer (2010) — on the current account and investment of foreign countries:

$$
y_{j, t+h}-y_{j, t-1}=\alpha_{j}^{h}+\beta^{h} F_{S h o c k}+\sum_{p=1}^{n} \gamma^{h} X_{j, t-p}+\varepsilon_{j, t+h},
$$

where $y_{j, t}$ is the log of exchange rate-adjusted cross-border claims from the U.S. located global banks to borrowers in countries $j$ in time $t ; F$ shock $k_{t}$ is a measure of exogenous U.S. fiscal shocks: RZ or RR shocks. $X_{j, t}$ is a set of control variables including lags of the dependent variable $y_{j, t}$ and the fiscal shock variable $F$ shock $_{t}$, and various control variables in the recipient country $j$ and their lags. To keep our specification parsimonious, in the baseline analysis, we control for real GDP growth and the policy rate in recipient countries..$^{18} \alpha_{j}^{h}$ is a recipient country-fixed effect, which controls unobserved time-invariant characteristics specific for a country $j$. Following Auerbach and Gorodnichencko (2012) and Feyrer and Shambaugh (2012), standard errors are clustered by time to account for the fact that the shock is identical for all countries in any given period.

As discussed above, we use two sets of the identified U.S. fiscal shocks from the recent literature. Our benchmark is data on quarterly government spending shocks constructed by Ramey and Zubairy (2018). While we use data on quarterly tax shocks collected by Romer and Romer (2010) for a robustness check, one should note that adjustments in government spending and taxes do not need to have symmetric effects (Mountford and Uhlig, 2009). Following Romer and Romer (2010)

\footnotetext{
${ }^{18}$ When policy rates are not available, we use interbank rates. When interbank rates are not available, we use money market rates.
} 
and Auerbach and Gorodnichencko (2012), we normalize the size of fiscal shocks by the size of GDP in the last period to rule out the contemporaneous fiscal multiplier effect. Equation (2) is estimated for $h=0,1,2, \ldots, 7$ so that we trace the dynamic effect of fiscal shocks over two years.

After dropping outliers and missing observations following the criterion explained above, our baseline estimation of the U.S. fiscal shocks includes cross-border lending to 45 recipient countries. ${ }^{19}$ In the baseline analysis, we use four lags of control variables in $X_{j, t}$ (i.e., $n=4$ ), but the selection of the lag length does not affect our findings in a meaningful way. When using RR shocks, our estimation period covers until 2007Q4. We first present the regression results by estimating equation (2) using both measures of fiscal shocks then plot the impulse-response functions to ease interpretation of our findings.

\section{RESUlts}

\section{A. Analysis of Cross-border Spillovers for U.S. Fiscal Shocks}

\section{Baseline results}

Table 3 summarizes the regression coefficients with their statistical significance obtained by estimating equation (2). The coefficients on the lagged dependent variable are negative and highly statistically significant, suggesting that the growth rate of the cross-border bank lending is meanreverting. The coefficients on a recipient country's real GDP growth are positive and statistically significant in most cases, which is consistent with the stylized fact that local economic growth is a strong pull factor of international capital flows.

Somewhat strangely, the sign on a recipient country's policy rate is largely negative and significant, suggesting that global banks in the U.S. lend less to a country with a higher domestic policy rate. While this finding is in contrast to Bruno and Shin (2015a) who find that a higher interest rate in a recipient country increases cross-border bank lending, it is mostly driven by emerging market recipient economies where the interest rate is countercyclical. In such economies, a higher interest rate often signals economic recessions or financial crises due to an increase in the higher risk premium. When we restrict our recipient countries to be advanced economies only, we find a positive and statistical coefficient on the recipient country's policy rate.

\footnotetext{
${ }^{19}$ Estonia, Latvia, Slovenia, and Ukraine among the countries presented in Table 1 are dropped in this analysis.
} 
Most importantly, we find that expansionary fiscal shocks increase cross-border bank lending from the U.S. significantly. A one percent increase in RZ's exogenous government spending as a share of GDP leads to about a 3.3 percent increase in cross-border bank lending after two quarters. The effect is larger for revenue shocks, with a decrease in RR's exogenous tax change of one percent of GDP increasing cross-border bank lending by 5.6 percent at the peak (after one year). ${ }^{20}$ However, one should note that the size of a typical exogenous spending shock is much larger than a typical exogenous revenue shock as shown in Figure 3, implying that an exogenous tax cut of one percent of GDP is an unusually large shock.

Figure 4 visualizes the dynamic response of cross-border bank lending presented in Table 3. The left panel in Figure 4 shows the response using RZ's government spending shocks, while the right panel shows the response using RR's exogenous tax shocks. While we obtain a wider confidence band from using RR's exogenous shocks, this is not surprising as we only have nine RR's exogenous shocks during our sample period. For the rest of the paper, we report the impulse response functions rather than estimation tables to ease interpretation.

\section{Robustness checks}

In this section, we test the robustness of the finding that expansionary domestic fiscal shocks in the U.S. economy increase cross-border bank lending from the U.S. We investigate the sensitivity of our results to (i) the inclusion of domestic control variables, (ii) different lag length selections, (iii) an alternative way of computing standard errors, and (iv) controlling for bilateral imports. To save space, the impulse response functions are presented in the appendix, and we discuss them only briefly in the main text.

Since the measures of fiscal shocks are exogenous, we do not control for any other macroeconomic variables in the U.S. economy in the baseline analysis. However, we still control for various factors that are known to affect cross-border banking flows to confirm the exogeneity of the fiscal shocks. Based on the extensive literature on international capital flows, we consider the four lags of the following set of controls: real GDP growth, stock market growth (S\&P500), the CPI inflation rate, the monetary policy rate (federal funds rate), and nominal effective exchange rate

\footnotetext{
${ }^{20}$ The larger effect on cross-border bank lending of a tax cut than government spending — when they are measured as a share of GDP - is in line with the finding of Mountford and Uhlig (2009) that deficit-financed tax cuts have a larger effect on GDP than deficit-financed spending.
} 
growth. ${ }^{21}$ As shown in Figure B.1 in the appendix, the inclusion of additional control variables does not result in any material changes in the impulse response functions, lending support to the exogeneity of the identified fiscal shocks we used.

We have used four lags of the dependent variables and control variables given the quarterly frequency of the data. We demonstrate that our findings do not depend critically on the selection of lag length by showing the estimation results alternatively using eight lags. Figure B.2 in the appendix confirms that our results hardly change with the selection of lag length. ${ }^{22}$

While we have clustered standard errors at the time level in the baseline specification, we test the robustness of our findings by clustering standard errors at the recipient country level or at the recipient country-time level. We also use Driscoll-Kraay standard errors that allow arbitrary correlations of the errors across countries and time. We only report the results from using DriscollKraay standard errors in Figure B.3 in the appendix to save space, but standard errors clustered by the recipient country-level and the recipient country time-level are similar to those clustered by the timelevel. In sum, the statistical significance of our findings does not hinge on the way we account for the correlations in the error term.

The use of the recipient country-fixed effect and a recipient country's macroeconomic variables cannot fully control for potential time-varying factors affecting cross-border banking flows at the bilateral level. One obvious candidate of such factors is bilateral trade flows between the U.S. and its counterpart countries. This variable is particularly relevant for the study of international capital flows, as the current account and the financial account are tightly related by the accounting identity, and the trade balance is a major determinant of the size of the current account. Moreover, Auerbach and Gorodnichencko (2013) show that a share of government purchases translates (directly or indirectly) into imports from other countries, which stimulate demand in those countries.

While our use of the variable corresponding to only a subset of total capital flows - the sum of direct investment, portfolio equity, and debt and other investment flows - mitigates this criticism, ${ }^{23}$ we test the robustness of our findings by adding extra control variables capturing bilateral trade flows.

\footnotetext{
${ }^{21}$ See Choi and Furceri (2018) for detailed discussions on choosing control variables.

${ }^{22}$ We also test the robustness of our results using two lags and find that the impulse response functions are very similar. To save space, this result is available upon request.

${ }^{23}$ The category "other investment" is the residual in the balance of payment statistics and includes loans, currency and deposits, and trade credits.
} 
We take bilateral trade flow data from the IMF Directions of Trade Statistics. We add the growth of U.S. imports (and their lags) from a country $j$ and re-estimate equation (1). Figure B.4 shows that our results are nearly identical when controlling for the bilateral import channel, consistent with the finding from Choi and Furceri (2018) that bilateral banking flows are largely independent of bilateral trade flows. ${ }^{24}$

\section{Transmission channels}

The effect of domestic fiscal shocks on cross-border bank lending depends on the initial response of domestic variables influencing these flows, such as the GDP, the interest rate, and the exchange rate. In this section, we estimate the effect of the exogenous fiscal shocks on the real effective exchange rate and real interest rate (their effect on ouput is well documented, see Romer and Romer (2010) and Ramey and Zubairy (2018). To the extent that these shocks are orthogonal to the contemporaneous macroeconomic conditions of the U.S. economy, we do not need to control for other variables:

$$
y_{t+h}-y_{t-1}=\alpha^{h}+\beta^{h} \text { shock }_{t}+\sum_{p=1}^{n} \gamma^{h} X_{t-p}+\varepsilon_{t+h},
$$

where $y_{t}$ is either the log of real effective exchange rate or the real policy rate (the federal funds rate minus the realized annual CPI inflation rate) in time $t ; X_{t}$ is a set of control variables including lags of the dependent variable $y_{t}$ and fiscal shock variable Fshock $_{t}$.

Figure 5 shows the dynamic responses of each variable to both fiscal shocks during the sample period. First, we do not find evidence for the traditional Mundell-Fleming channel, as real exchange rate depreciates, not appreciates after expansionary spending and revenue shocks (in Panel A). However, such real depreciation following expansionary fiscal shocks in the U.S. is consistent with many empirical studies using structural VARs (Kim and Roubini, 2008; Corsetti et al., 2012; Ravn et al., 2012). ${ }^{25}$ In contrast, we find some evidence for the monetary accommodation channel, as shown in Panel B of Figure 5. Monetary authorities tend to lower the policy interest rate following the spending (or revenue) shock, which is consistent with the finding of Kim and Roubini (2008) when

\footnotetext{
${ }^{24}$ Our conclusions hardly change when we use export growth instead of import growth.

${ }^{25}$ As an attempt to identify the source of the real exchange rate response, we replace the real effective exchange rate with the nominal effective exchange rate. We find that the nominal effective exchange rate also depreciates significantly, implying that the real exchange rate depreciation following the expansionary fiscal shock is largely driven by the nominal exchange rate depreciation.
} 
they use real government consumption as a measure of fiscal expansion. ${ }^{26}$ The monetary accommodation in response to a domestic fiscal expansion seems an important determinant of the cross-border fiscal-financial spillovers. According to the standard bank lending channel, a decline in the domestic policy rate in response to a fiscal expansion makes lending to foreign borrowers more attractive for domestic banks by reducing funding costs. As a result, cross-border lending (outflows) from the domestic banking sector exceeds cross-border borrowing (inflows) of the domestic banking sector, which increases its net foreign asset position (corresponding to current account improvement) and depreciates the domestic currency.

\section{Fiscal shocks vs. monetary policy shocks and VIX}

To test whether fiscal shocks have an independent effect on cross-border lending, we reestimate the impulse response functions by controlling for monetary policy shocks. We employ the exogenous monetary policy shock series constructed by Coibion (2012) who extends the monetary policy shocks identified by Romer and Romer (2004) using a narrative approach. Romer and Romer (2004) extract measures of the change in the Fed's target interest rate at each meeting of the Federal Open Market Committee (FOMC) and regress this measure of policy changes on the Fed's real-time forecasts of relevant macroeconomic variables. They identify an exogenous measure of monetary policy shocks by taking the residuals from the regression above. Coibion (2012) further extends this monetary policy shock series by explicitly allowing for heteroskedasticity in the innovation via a GARCH modeling. ${ }^{27}$

We add the contemporaneous and the four lags of this monetary policy shock variable to Equation (2). Figure 6 shows that both measures of fiscal shocks still have significant effects on cross-border bank lending independent of monetary policy shocks. ${ }^{28}$ Interestingly, exogenous monetary policy shocks have a significantly negative effect on cross-border bank lending (Figure B.5 in the appendix), which is in sharp contrast to the finding of Cerutti et al. (2017) and Correa et al. (2017) who find a positive effect of domestic monetary tightening on cross-border bank lending using the policy rate itself as a measure of monetary policy shocks. On the other hand, our finding is consistent with Avdjiev and Hale (2018) and Albrizio et al., (forthcoming) who find a negative

\footnotetext{
${ }^{26}$ We obtain a similar result by using the $\mathrm{Wu}-\mathrm{Xia}$ shadow federal funds rate (Wu and Xia, 2016) instead since 2009.

${ }^{27}$ Fiscal shocks identified by Ramey and Zubairy (2018) and monetary policy shocks identified by Coibion (2012) are indeed near orthogonal (correlation of 0.01 ).

${ }^{28}$ The estimation period is from 1990Q1 to 2008Q4, as the monetary policy shock series is only available until $2008 \mathrm{Q}$.
} 
relationship between the U.S. federal funds rate and cross-border bank lending to emerging market economies when an increase in the federal funds rate is driven by exogenous changes in the monetary policy stance. In this joint estimation of the exogenous fiscal and monetary policy shocks, the effect of a one percent increase in government spending (tax cut) as a share of GDP on cross-border bank lending is equivalent to that of an exogenous decrease in the federal funds rate by $25 \mathrm{bp}(100 \mathrm{bp})$, suggesting that the effect of fiscal shocks is not only statistically but economically significant.

Given the importance of the VIX in driving the global financial cycle (Rey, 2015), a natural question is whether our findings are biased due to the omission of this variable. To address this issue and compare the importance of domestic fiscal shocks in driving cross-border banking flows with that of a global financial cycle, we augment Equation (2) with both exogenous monetary policy shocks and the VIX (and their four lags). Figure B.6 in the appendix confirms that the effect of domestic fiscal shocks on cross-border bank lending is independent of both U.S. monetary policy and a global financial cycle measured by the VIX. ${ }^{29}$

To further examine the importance of domestic fiscal shocks in driving cross-border banking flows, we decompose the variation in cross-border bank lending into the one explained by the various explanatory variables: the lags of the cross-border bank lending themselves, recipient-country GDP growth, the recipient-country policy rate, domestic fiscal shocks, domestic monetary policy shocks, and the VIX shocks. Figure 7 shows a lion's share of the variation in cross-border bank lending is explained by its own lags. The macroeconomic conditions in a recipient country - a proxy for credit demand-also explain a non-negligible share of cross-border bank lending. Not surprisingly, monetary policy shocks explain the largest share of the variation for most horizons (except for the lags of cross-border bank lending themselves), consistent with the previous studies on the link between monetary policy and cross-border banking flows (Bruno and Shin, 2015b; Correa et al., 2017; Avdjiev and Hale, 2018; Albrizio et al., forthcoming). At the same time, fiscal shocks also play a non-negligible role in explaining the fluctuations in cross-border bank lending; their contribution to cross-border bank lending tends to be larger than VIX shocks over most horizons, and it is even larger than monetary policy shocks on impact, suggesting that fiscal shocks are an independent and important driver of these flows.

\footnotetext{
${ }^{29}$ The response of cross-border bank lending to the fiscal shocks hardly changes when we replace the VIX with U.S. economic policy uncertainty constructed by Baker et al. (2016).
} 


\section{Effects on banks' net foreign asset position}

To shed more light on the transmission channel of fiscal shocks, we re-estimate equation (2) using domestic banks' net foreign asset position, which corresponds conceptually to the current account balance. By looking at gross outflows and inflows separately, we can also identify a source of changes in net flows following domestic fiscal shocks. We normalize the net foreign asset position (bilateral cross-border claims minus liabilities) by the recipient country's lagged nominal GDP (i.e., $\left.Y_{j, t}=\frac{\text { claims }_{j, t}-\text { liabilites }_{j, t}}{G D P_{j, t-1}}\right)^{30}$

Figure 8 shows the response of the net foreign asset position in response to both types of fiscal shocks. Consistent with some empirical studies that found the improvement in the current account after a domestic fiscal expansion, we find that the net foreign asset position by the domestic banking sector increases significantly. ${ }^{31}$ Figure B.7 in the appendix also plots the response of cross-border borrowing separately by replacing the log of exchange rate-adjusted cross-border claims in equation (2) with the log of exchange rate-adjusted cross-border liabilities. Cross-border borrowing does not respond significantly to domestic fiscal shocks, suggesting that an increase in the net foreign asset position found in Figure 6 is mostly driven by an increase in cross-border claims.

\section{Fiscal-financial spillovers during recessions vs. expansions}

So far we have found robust evidence that an expansionary U.S. fiscal shock increases crossborder bank lending from the U.S. However, there is vast empirical evidence that the effect of fiscal shocks on output is nonlinear (Perotti, 1999; Auerbach and Gorodnichencko, 2012; Caggiano et al., 2015). Thus, the average response of cross-border bank lending we found may mask substantial heterogeneity depending on the underlying economic regime at the time of the shock (good vs. bad times) or a type of shocks (fiscal stimulus vs. fiscal austerity). We estimate nonlinear versions of equation (2) to account for this possibility. For the remaining exercises, we focus on the measure of RZ shocks, as it allows more data to estimate nonlinear models with a larger set of parameters and it

\footnotetext{
${ }^{30}$ Unlike the previous case of cross-border asset positions, we cannot take the log of net position. Instead, we normalize the net position by the size of a recipient country's GDP: $y_{j, t}=\frac{\text { claims }_{j, t}-\text { liabilites }_{j, t}}{G D P_{j, t-1}}$ and $y_{j, t+h}=\frac{\text { claims }_{j, t+h}-\text { liabilites }_{j, t+h}}{G D P_{j, t-1}}$.

${ }^{31}$ Our results are robust to the weighted regression where observations are weighted by the recipient country's nominal GDP.
} 
is conceptually consistent with AG's spending shocks used in the analysis of small open economies. The results obtained with RR's revenue shocks are qualitatively similar and available upon request.

We estimate the following equation in which the dynamic response is allowed to vary with the state of the economy:

$$
\begin{aligned}
y_{j, t+h}-y_{j, t-1} & =F\left(z_{t}\right)\left(\alpha_{R, j}^{h}+\sum_{p=1}^{n} \gamma_{R}^{h} X_{j, t-p}+\beta_{R}^{h} F \text { shock }_{t}\right) \\
& +\left(1-F\left(z_{t}\right)\right)\left(\alpha_{E, j}^{h}+\sum_{p=1}^{n} \gamma_{E}^{h} X_{j, t-p}+\beta_{E}^{h} F \text { shock }_{t}\right)+\varepsilon_{j, t+h}
\end{aligned}
$$

with $F\left(z_{t}\right)=\frac{\exp \left(-\theta z_{t}\right)}{1+\exp \left(-\theta z_{t}\right)}$ and $\theta>0$,

where $z_{t}$ is an indicator of the state of the economy normalizd to have a unit variance. The estimated parameters depend on the average behavior of the economy in the historical sample between $t$ and $t+h$, given the shock, the initial state, and the control variables. The parameter estimates on the control variables incorporate the average tendency of the economy to evolve between states. Therefore, the estimates incorporate both natural transitions and endogenous transitions from one state to the other that occur on average in the data. The indicator of the state of the economy is the five-quarter moving average of real GDP growth and $F\left(z_{t}\right)$ is a smooth transition function used to estimate the effect of fiscal shocks in expansions vs. recessions. ${ }^{32}$ We choose $\theta=1.5$ following Auerbach and Gorodnichencko (2012) and calibrate the mean of $z_{t}$ so that the economy spends about 20 percent of the time in a recessionary regime. ${ }^{33}$

This approach is equivalent to the smooth transition autoregressive model developed by Granger and Terävistra (1993) and has the following advantages. First, compared with a model in which each dependent variable would interact with a measure of the business cycle position, it permits a direct test of whether the effect of fiscal shocks on cross-border banking flows varies across different regimes. Second, compared with estimating structural VARs for each regime, it allows the effect of fiscal shocks to change smoothly between recessions and expansions by considering a continuum of states to compute the impulse response functions, thus making the response more stable and precise. Third, we can use our full sample for estimation, which makes our estimates as precise

\footnotetext{
32 The results, available upon request, are similar when considering a measure of output gap instead.

${ }^{33}$ Our results hardly change when using alternative parameter values of $\theta$ between 1 and 6 .
} 
and robust as possible. As shown in Figure 9, the probability of a recession regime we estimate using a smooth transition function captures well the official NBER recession dates.

The coefficients $\beta_{E}^{h}$ and $\beta_{R}^{h}$ trace the dynamic response to fiscal shocks when the economy is in recessions and expansions, respectively. Figure 10 contrasts the dynamic responses during recessions and expansions using RZ's spending shocks. Consistent with the existing empirical evidence regarding the size of fiscal multipliers, the average response of cross-border bank lending to an increase in government spending in Figure 4 also masks substantial heterogeneity depending on the underlying economic regime. Fiscal-financial spillovers tend to be larger when a fiscal expansion in the source economy is undertaken during a period of slack. This larger effect is consistent with the prevailing empirical evidence of larger fiscal multipliers during recessions and the recent finding by Auerbach and Gorodnichencko (2013) that international fiscal-output spillovers are larger when a source country is in recessions.

\section{Fiscal-financial spillovers of fiscal stimulus vs. fiscal austerity}

The adverse effect of fiscal austerity on cross-border banking flows may be different than the positive effect of the same size of the fiscal stimulus. To test for this potential asymmetry, we estimate the following specification:

$$
y_{j, t+h}-y_{j, t-1}=\alpha_{j}^{h}+\beta_{+}^{h} D_{t} F \text { shock }_{t}+\beta_{-}^{h}\left(1-D_{t}\right) F \text { shock }_{t}+\sum_{p=1}^{n} \gamma^{h} X_{j, t-p}+\varepsilon_{j, t+h},
$$

where $D_{t}$ is a dummy variable that takes a value of one for an increase in government spending, and zero otherwise. Then we trace the coefficients $\beta_{+}^{h}$ and $\beta_{-}^{h}$ to gauge the effect of a fiscal expansion and consolidation, respectively. The strong asymmetric responses are presented in Figure 11; the adverse effect of fiscal consolidation on cross-border bank lending is larger than the positive effect of the same size of a fiscal expansion in an absolute term, suggesting that a fiscal consolidation in the U.S. has a more negative spillover effect into other countries than the one implied by the baseline estimation.

\section{Fiscal-financial spillovers and recipient countries' characteristics}

In this section, we ask whether certain types of a recipient country's characteristics amplify or dampen the cross-border fiscal-financial spillover effect we found in the previous section. Guided by the well-known Mundellian trilemma that countries can pursue two of three options: fixed exchange rates, domestic monetary autonomy, and capital mobility (Mundell, 1963; Obstfeld et al., 
2005), we ask whether the exchange rate regime and capital openness affect the size of international fiscal-financial spillovers. Although international fiscal-financial spillovers might be beneficial for recipient countries without their own fiscal space in stimulating aggregate demand, they could equally have a de-stabilizing effect if a fiscal consolidation in a large and systematic economy is directly exported to a country in needs of external financing. For example, Hahm et al. (2013) show that this "non-traditional" form of financing is associated with greater risk-taking in the banking sector, thereby making the domestic financial system more likely to be linked to international capital markets and hence sensitive to global conditions. The fact that recipient countries can experience volatility for reasons independent of domestic policies makes answering this question particularly relevant from a financial stability perspective.

Again, compared to structural VARs, the local projection method allows for a straightforward interaction between domestic fiscal shocks and characteristics of the recipient countries. We estimate the following equation which is a minor extension of equation (5):

$$
y_{j, t+h}-y_{j, t-1}=\alpha_{j}^{h}+\beta_{1}^{h} D_{j, t} F_{\text {shock }}+\beta_{2}^{h}\left(1-D_{j, t}\right) F_{\text {shock }}+\sum_{p=1}^{n} \gamma^{h} X_{j, t-p}+\varepsilon_{j, t+h} .
$$

The only difference from equation (5) is that now we interact $F$ shock $k_{t}$ with an indicator variable $D_{j, t}$ regarding the status of each recipient country in time $t$; and $X_{j, t}$ also includes the four lags of $D_{j, t}$. For example, when testing the role of exchange rate regimes, $D_{j, t}$ takes a value of one if a recipient country $j$ is classified as a fixed exchange rate regime (peg) with respect to the U.S. in time $t$, and zero, otherwise.

We use the updated version of binary regime classification by Shambaugh (2004) to sort out de facto pegged and floating exchange rate regimes. In Shambaugh's classification, a country is classified as pegged if its official nominal exchange rate stays within \pm 2 percentage bands over the course of the year against the base country. The base country is chosen based on the declared base, the history of a countries' exchange rate, by comparing its exchange rate to a variety of potential bases, and by looking at dominant regional currencies. Non-pegs are also assigned a base determined by the country they peg to when they are pegging at other times in the sample. The floating regime does not necessarily include pure floats only but includes all sorts of non-pegged regimes. ${ }^{34}$ In the

\footnotetext{
${ }^{34}$ We download the updated annual dataset from Shambaugh Exchange Rate Regime Classification and use the most basic measure of the exchange rate regime employed in Shambaugh (2004).

https://www2.gwu.edu/ iiep/about/faculty/jshambaugh/Shambaughexchangerate.pdf provides further details on the construction of the dataset.
} 
analysis of the international panel data in the following section, we use country-specific base currencies other than the dollar and account for the introduction of the euro. ${ }^{35}$

In the case of capital account openness, we use the updated version of the Chinn-Ito index (Chinn and Ito, 2008). This index is a widely-used de facto measure of the country's capital controls and available back to 1970 for a large group of countries. Specifically, we focus on the KAOPEN measure of capital controls in Chinn and Ito (2008), updated in July 2017. KAOPEN is based on the four binary dummy variables that codify the tabulation of restrictions on cross-border financial transactions reported in the IMF's Annual Report on Exchange Arrangements and Exchange Restrictions: (i) capital account openness; (ii) current account openness; (iii) the stringency of requirements for the repatriation and/or surrender of export proceeds; and (iv) the existence of multiple exchange rates for capital account transactions.

Figure 12 reports the financial spillover effects of U.S. fiscal shocks across recipient countries depending on their exchange rate regime. If anything, the results suggest that the response tend to be smaller in countries with currencies pegged to the U.S. dollar, although the standard errors for the pegged recipient countries are fairly large, ${ }^{36}$ leaving the difference of the effects between the two groups statistically insignificant. In this regard, this finding is consistent with Rey (2015), who argues that cross-border financial spillovers are similar for fixed and flexible exchange rate countries - implying the irrelevance of the exchange rate regime for cross-border financial spillovers.

Figure 13 presents the results for capital account openness. Consistent with Ostry et al. (2010), the effect is smaller for countries with a relatively low degree of capital openness, indicating that capital controls can dampen cross-border financial spillovers of fiscal shocks. Lastly, we test whether the spillovers differ depending on the level of development of a recipient country: advanced vs. emerging market economies. ${ }^{37}$ Interestingly, the difference in the impulse response functions between advanced- and emerging market-recipient economies (shown in Figure B.8 in the appendix) is similar to that between financially open- and closed- counterpart countries in Figure 13. Indeed, the

\footnotetext{
${ }^{35}$ The base countries for pegs are obvious; the base for nonpegs, while conceivably difficult to isolate, are in fact almost equally obvious. Most countries generally only peg to one country during the sample and nearly all peg at some point, thus revealing the base. Further, those that do switch bases, tend to switch directly from one peg to another (e.g., Ireland in 1979), so no ambiguous middle float exists. For the few countries that do not peg, currency history is used and the dollar in very rare cases (Japan) where no obvious other choice exists. After the introduction of the euro, all euro-zone countries in our sample are treated as pegged to each other.

${ }^{36}$ Only a quarter of recipient country-time observations are classified as a pegged regime.

${ }^{37}$ The classification of counties in advanced and merging market economies follows the IMF World Economic Outlook.
} 
degree of capital openness of each country is strongly correlated with its income status, highlighting an empirical difficulty of separating these two channels.

\section{B. Analysis of Cross-border Fiscal-Financial Spillovers in Small Open Economies}

We test whether the financial spillover effect of domestic fiscal shocks in the U.S. can be generalized to a group of 16 (small open) advanced economies. While the textbook theory predicts a stark difference between closed and open economies regarding the effect of a fiscal expansion on domestic economic variables, such as the interest rate, private investment, the exchange rate, and net exports, the impact on cross-border fiscal-financial spillovers falls into an area of empirical questions.

In the baseline analysis, we estimate equation (1) using the bilateral cross-border banking data between 16 source countries and their (maximum of) 49 recipient countries and the semi-annual data of exogenous government spending shocks constructed by Auerbach and Gorodnichencko (2012). In the baseline analysis, we use two lags of control variables in $X_{i, j, t}$ (i.e., $n=2$ ). Our baseline estimation covers an unbalanced panel of 624 source-recipient country pairs from 1990 to 2010. Figure 14 plots the distribution of exogenous government spending shocks in 16 OECD countries, showing that positive and negative exogenous spending shocks exist nearly equally in the data. Table 4 shows the average size and standard deviation of country-specific exogenous spending shocks, together with the correlation with U.S. exogenous spending shocks. The size of exogenous spending shocks - measured by the standard deviation — is quite similar across countries, while the correlation with U.S. fiscal shocks is fairly heterogenous - ranging from -0.445 in the U.K. to 0.413 in Denmark-, suggesting an idiosyncratic nature of the identified shocks.

\section{Baseline results}

Figure 15 shows the response of cross-border lending to these exogenous spending shocks. Consistent with the U.S. evidence, we find positive and significant effects of an exogenous increase in government spending on cross-border bank lending in the case of 16 OECD countries. One percent of GDP increase in exogenous government spending leads to an about 4 percent increase in crossborder bank lending after one year, suggesting that the effect of fiscal-financial spillovers is not only statistically but also economically significant among small open economies. However, one should note that the nature and the size of AG's fiscal shocks differ from those of RZ's fiscal shocks. As 
shown in Table 4, the typical AG's spending shock among 16 OECD countries is much smaller than RZ's spending shocks. ${ }^{38}$

\section{Robustness checks}

We check the role of the various fixed effects in estimating the above impulse response functions by re-estimating the equation with (i) the source-recipient fixed effect only and (ii) the recipient-time fixed effect only. Figure B.9 in the appendix shows that an increase in cross-border bank lending is very robust to the different combination of the fixed effects. Similar to the analysis of U.S. fiscal shocks, we conduct the following sensitivity tests: (i) controlling for other domestic macroeconomic variables, such as real GDP growth, stock market growth, the CPI inflation rate, the monetary policy rate, and nominal exchange rate growth; (ii) alternative standard error clustering; (iii) including more lags; and (iv) controlling for bilateral import growth. Our findings are largely unaffected by these alternative specifications, and the results are available upon request.

\section{Additional exercises}

We also investigate potential nonlinearities in international fiscal-financial spillovers by estimating bilateral versions of nonlinear equations (4) and (5) in turn. Following Auerbach and Gorodnichencko (2012), we use 1.5 years moving average of real GDP growth to construct $z_{i, t}$, a country-specific indicator of the state of the economy in the case of semi-annual international panel data. Again, we trace the coefficients $\beta_{E}^{h}$ and $\beta_{R}^{h}$ to measure the dynamic response to fiscal shocks when the economy is in recessions and expansions, respectively. Figure B.10 in the appendix contrasts the dynamic responses during recessions and expansions using AG shocks, which shares a similar pattern found in the analysis of the U.S. economy using RZ shocks: the positive spillovers are stronger during recessions than expansions. Nevertheless, we cannot provide a definite answer due to the large confidence intervals surrounding the estimates

Figure B.11 in the appendix also confirms the finding from the analysis of the U.S. economy where the negative effect of a fiscal consolidation on cross-border bank lending is larger than the positive effect of the same size of a fiscal expansion in an absolute term. To the extent that most countries in this sample are European countries, this finding corroborates the concerns over the negative cross-border spillovers to their trading partners by recent fiscal consolidations adopted by

\footnotetext{
${ }^{38}$ Because AG's fiscal shocks are estimated outside of the local projection model adopted in this analysis, the confidence intervals may be wider than those in Figure 15 if uncertainty around the estimated shocks is considered.
} 
many European economies (Goujard, 2017). Our contribution is to highlight financial linkages as a transmission channel, in addition to trade linkages emphasized in the previous studies.

Figure B.12 and B.13 in the appendix report the results from estimating the small open economies counterpart to the results from the U.S. economy presented in Figure 12 and 13. The specification we use here mirrors the earlier ones. In Figure B.12 in the appendix, we find some evidence that the effects depend on the recipient countries' exchange rate regime, consistent with the U.S. case, although the large standard errors do not provide us clear-cut evidence. Figure B.13 in the appendix presents the results for capital account openness. In this case, the effects are not statically different between countries with relatively high and low degree of current account openness. While it may seem odd that even countries with relatively high capital controls are affected by changes in foreign fiscal policies, it is also the case that only a few countries with capital controls truly shut off access to capital markets. In addition, the results are consistent with some studies suggesting that capital controls tend to have a significant effect on the composition of capital flows but more limited effects on the overall magnitude (e.g., Edwards, 2007).

\section{CONCLUSION}

The Global Financial Crisis re-enkindled the debate on the role of fiscal policy as a key stabilization tool and on the potential of fiscal policy to affect economic activity in other economies through cross-border spillovers. To what extent fiscal policy spills over into other countries is a key question in the current context of a fiscal expansion in large and systemic economies such the U.S. While previous studies have typically analyzed the existence of fiscal spillovers through trade linkages, less is known about the magnitude of fiscal spillovers through financial linkages. This paper contributes to this literature by providing the first analysis - to the best of our knowledge — of the international financial spillovers of domestic fiscal shocks. Our analysis on both gross flows and net flows also allows us to identify a potential source of current account improvement following an expansionary fiscal shock, thereby contributing to the emerging literature emphasizing gross capital flows as a new determinant of global financial stability (Obstfeld, 2012; Broner et al., 2013).

By investigating the cross-border spillovers of exogenous fiscal shocks in both the U.S. and 16 other advanced economies, we document that fiscal policy in a source economy has economically and statistically significant effects on cross-border bank lending to other economies and these effects are largely independent of bilateral trade flows. Overall, the strength of the spillovers is larger when a fiscal expansion in source countries is undertaken during periods of weak economic activity. In 
addition, the effect of a fiscal consolidation is typically larger than that of the same-magnitude in a fiscal expansion. These results suggest that coordination of fiscal policies is more valuable than previously thought. Monetary accommodation following a fiscal expansion seems to be a key factor to generate positive spillover effects, but the effect of fiscal policy shocks is quite independent of monetary policy shocks or financial shocks.

The results of the paper also speak to the policy debate on the ability of recipient economies to dampen capital inflows, thereby mitigating potential negative externalities. We find some suggestive evidence that capital controls are effective in moderating capital inflows, although no definitive statements can be made due to large standard errors. We also find that the degree of fiscalfinancial spillovers is not significantly different depending on a recipient country' exchange rate regime, suggesting — as argued by Rey (2015) — that the exchange rate regime is mostly irrelevant for cross-border financial spillovers. 


\section{References}

Albrizio, Siliva, Sangyup Choi, Davide Furceri and Cahnsik Yoon. "The Effect of Conventional and Unconventional Monetary Policy on Cross-border Bank Lending” IMF Working Papers

(forthcoming).

Auerbach, Alan J., and Yuriy Gorodnichenko. "Fiscal multipliers in recession and expansion." Fiscal policy after the financial crisis. University of Chicago Press, 2012. 63-98.

Auerbach, Alan J., and Yuriy Gorodnichenko. "Output spillovers from fiscal policy." American Economic Review 103.3 (2013): 141-46.

Avdjiev, Stefan, and Elod Takáts. "Cross-border bank lending during the taper tantrum: the role of emerging market fundamentals.” BIS Quarterly Review (2014).

Avdjiev, Stefan, and Galina Hale. "US monetary policy and fluctuations of international bank lending." Federal Reserve Bank of San Francisco, 2018.

Baker, Scott R., Nicholas Bloom, and Steven J. Davis. "Measuring economic policy uncertainty." Quarterly Journal of Economics 131.4 (2016): 1593-1636.

Bank of International Settlement. "BIS Quarterly Review.” 2017

Baskaya, Yusuf Soner, Julian Di Giovanni, Şebnem Kalemli-Özcan, José-Luis Peydro, and Mehmet Fatih Ulu. "Capital flows and the international credit channel." Journal of International Economics 108 (2017): S15-S22.

Beetsma, Roel, Massimo Giuliodori, and Franc Klaassen. "The effects of public spending shocks on trade balances and budget deficits in the European Union." Journal of the European Economic Association 6.2-3 (2008): 414-423.

Blanchard, Olivier, and Roberto Perotti. "An empirical characterization of the dynamic effects of changes in government spending and taxes on output." Quarterly Journal of Economics 117.4 (2002): $1329-1368$.

Blanchard, Olivier, Christopher J. Erceg and Jesper Lindé, 2017. "Jump-Starting the Euro-Area Recovery: Would a Rise in Core Fiscal Spending Help the Periphery?” NBER Macroeconomics Annual, University of Chicago Press, vol. 31(1), pages 103-182.

Broner, Fernando, Tatiana Didier, Aitor Erce, and Sergio L. Schmukler. "Gross capital flows: Dynamics and crises.” Journal of Monetary Economics 60, no. 1 (2013): 113-133.

Bruno, Valentina, and Hyun Song Shin. "Cross-border banking and global liquidity." Review of Economic Studies 82.2 (2015a): 535-564. 
Bruno, Valentina, and Hyun Song Shin. "Capital flows and the risk-taking channel of monetary policy.” Journal of Monetary Economics 71 (2015b): 119-132.

Caggiano, G., Castelnuovo, E., Colombo, V., \& Nodari, G. (2015). "Estimating Fiscal Multipliers: News from a Non-linear World.” Economic Journal, 125(584), 746-776.

Cetorelli, Nicola, and Linda S. Goldberg. "Global banks and international shock transmission: Evidence from the crisis." IMF Economic Review 59.1 (2011): 41-76.

Cerutti, Eugenio, Stijn Claessens, and Lev Ratnovski. "Global liquidity and cross-border bank flows." Economic Policy 32.89 (2017): 81-125.

Chinn, Menzie D., and Hiro Ito. “A new measure of financial openness.” Journal of Comparative Policy Analysis 10.3 (2008): 309-322.

Choi, Sangyup, and Davide Furceri. "Uncertainty and Cross-Border Banking Flows." IMF Working Paper 18/4. International Monetary Fund, 2018.

Coenen G, Erceg CJ, Freedman C, Furceri D, Kumhof M, Lalonde R, Laxton D, Lindé J, Mourougane A, Muir D, Mursula S. "Effects of fiscal stimulus in structural models." American Economic Journal: Macroeconomics. 2012 Jan; 4(1):22-68.

Coibion, Olivier. "Are the effects of monetary policy shocks big or small?" American Economic Journal: Macroeconomics 4.2 (2012): 1-32.

Correa, Ricardo, Teodora Paligorova, Horacio Sapriza, and Andrei Zlate. "Cross-Border Bank Flows and Monetary Policy.” Working Paper 2017.

Corsetti, Giancarlo, André Meier, and Gernot J. Müller. "Fiscal stimulus with spending reversals." Review of Economics and Statistics 94.4 (2012): 878-895.

Dabla-Norris, E., E.P. Dallari, and T. Poghosyan. "Fiscal Spillovers in the Euro Area: Letting the Data Speak”, IMF Working Paper (2017): 17/241.

Davig, Troy, and Eric M. Leeper. "Monetary-fiscal policy interactions and fiscal stimulus." European Economic Review 55.2 (2011): 211-227.

DeLong, J. Bradford, and Lawrence H. Summers. "Fiscal policy in a depressed economy." Brookings Papers on Economic Activity 2012.1 (2012): 233-297.

Driscoll, John C., and Aart C. Kraay. "Consistent covariance matrix estimation with spatially dependent panel data." Review of Economics and Statistics 80.4 (1998): 549-560.

Edwards, Sebastian, ed. 2007. "Capital Controls and Capital Flows in Emerging Economies: Policies, Practices, and Consequences." Chicago: University of Chicago Press. 
Eggertsson, Gauti B. "What fiscal policy is effective at zero interest rates?" NBER Macroeconomics Annual 25.1 (2011): 59-112.

Enders, Zeno, Gernot J. Müller, and Almuth Scholl. "How do fiscal and technology shocks affect real exchange rates?: New evidence for the United States.” Journal of International Economics 83.1 (2011): 53-69.

Faccini, Renato, Haroon Mumtaz, and Paolo Surico. "International fiscal spillovers." Journal of International Economics 99 (2016): 31-45.

Farhi, Emmanuel, and Iván Werning. "Fiscal Multipliers: Liquidity Traps and Currency Unions." Handbook of Macroeconomics. Vol. 2. Elsevier, 2016. 2417-2492.

Feyrer, James, and Jay Shambaugh. "Global savings and global investment: The transmission of identified fiscal shocks.” American Economic Journal: Economic Policy 4.2 (2012): 95-114.

Forbes, Kristin J., and Francis E. Warnock. "Capital flow waves: Surges, stops, flight, and retrenchment.” Journal of International Economics 88.2 (2012): 235-251.

Forni, Mario, and Luca Gambetti. "Government spending shocks in open economy VARs." Journal of International Economics 99 (2016): 68-84.

Goujard, Antoine. "Cross-Country Spillovers from Fiscal Consolidations." Fiscal Studies 38.2 (2017): 219-267.

Guajardo, Jaime, Daniel Leigh, and Andrea Pescatori. "Expansionary austerity? International evidence." Journal of the European Economic Association 12.4 (2014): 949-968.

Granger, Clive, and Timo Teräsvirta. "Modelling Non-Linear Economic Relationships.” Oxford University Press, 1993.

Hahm, Joon-ho, Hyun Song Shin, and Kwanho Shin. "Noncore bank liabilities and financial vulnerability." Journal of Money, Credit and Banking 45.s1 (2013): 3-36.

Ilzetzki, Ethan, Enrique G. Mendoza, and Carlos A. Végh. "How big (small?) are fiscal multipliers?" Journal of Monetary Economics 60.2 (2013): 239-254.

International Monetary Fund. "Dancing Together? Spillovers, Common Shocks, and the Role of Financial and Trade Linkages.” IMF World Economic Outlook, 2013.

International Monetary Fund. "Fiscal Spillovers: The Importance of Macroeconomic and Policy Conditions in Transmission.” IMF Spillover Notes, 2017.

Jordà, Òscar. "Estimation and inference of impulse responses by local projections." American Economic Review 95.1 (2005): 161-182. 
Kalemli-Ozcan, Sebnem, Elias Papaioannou, and Fabrizio Perri. "Global banks and crisis transmission.” Journal of International Economics 89.2 (2013): 495-510.

Kim, Soyoung. "Country characteristics and the effects of government consumption shocks on the current account and real exchange rate.” Journal of International Economics 97.2 (2015): 436-447.

Kim, Soyoung, and Nouriel Roubini. "Twin deficit or twin divergence? Fiscal policy, current account, and real exchange rate in the US." Journal of International Economics 74.2 (2008): 362-383.

Leeper, Eric M., Todd B. Walker, and Shu-Chun Susan Yang. "Fiscal foresight and information flows." Econometrica 81.3 (2013): 1115-1145.

Milesi-Ferretti, Gian-Maria, and Cédric Tille. "The great retrenchment: international capital flows during the global financial crisis.” Economic Policy 26.66 (2011): 289-346.

Miyamoto, Wataru, Thuy Lan Nguyen, and Viacheslav Sheremirov. "The effects of government spending on real exchange rates: evidence from military spending panel data." (2017).

Mountford, Andrew, and Harald Uhlig. "What are the effects of fiscal policy shocks?" Journal of Applied Econometrics 24.6 (2009): 960-992.

Mundell, R., "Capital Mobility and Stabilization Policy under Fixed and Flexible Exchange Rates," Canadian Journal of Economics and Political Science 29 (1963), 475-485.

Obstfeld, Maurice. "Financial flows, financial crises, and global imbalances." Journal of International Money and Finance 31.3 (2012): 469-480.

Obstfeld, M., J. Shambaugh, and A. Taylor, "The Trilemma in History: Tradeoffs among Exchange Rates, Monetary Policies, and Capital Mobility," Review of Economics and Statistics 87 (2005), 423 438.

Ostry, Jonathan D., Atish R. Ghosh, Karl Friedrich Habermeier, Marcos Chamon, Mahvash Qureshi, and Dennis B. S. Reinhardt. 2010. "Capital Inflows; The Role of Controls.” IMF Staff Position Notes. International Monetary Fund.

Perotti, Roberto. "Fiscal policy in good times and bad." Quarterly Journal of Economics 114.4 (1999): 1399-1436.

Ramey, Valerie A. "Can government purchases stimulate the economy?” Journal of Economic Literature 49.3 (2011): 673-85.

Ramey, Valerie A., and Sarah Zubairy. "Government spending multipliers in good times and in bad: evidence from US historical data.” Journal of Political Economy 126.2 (2018): 850-901.

Ravn, Morten O., Stephanie Schmitt-Grohé, and Martin Uribe. "Consumption, government spending, and the real exchange rate.” Journal of Monetary Economics 59.3 (2012): 215-234. 
Rey, H., "Dilemma not Trilemma: The Global Financial Cycle and Monetary Policy Independence," NBER Working Paper 21162 (2015).

Romer, Christina D., and David H. Romer. "A new measure of monetary shocks: Derivation and implications.” American Economic Review 94.4 (2004): 1055-1084.

Romer, Christina D., and David H. Romer. "The macroeconomic effects of tax changes: estimates based on a new measure of fiscal shocks." American Economic Review 100.3 (2010): 763-801.

Shambaugh, Jay C. "The effect of fixed exchange rates on monetary policy." Quarterly Journal of Economics 119.1 (2004): 301-352.

$\mathrm{Wu}$, Jing Cynthia, and Fan Dora Xia. "Measuring the macroeconomic impact of monetary policy at the zero lower bound.” Journal of Money, Credit and Banking 48.2-3 (2016): 253-291. 
Tables and Figures

Table 1. List of countries in the international panel analysis

\begin{tabular}{|c|c|c|c|c|c|c|c|}
\hline Source countries & $\begin{array}{c}=1 \text { if } \\
\text { advanced } \\
\text { economy }\end{array}$ & $=1$ if open & $=1$ if peg & Recipient countries & $\begin{array}{c}=1 \text { if } \\
\text { advanced } \\
\text { economy }\end{array}$ & $=1$ if open & $=1$ if peg \\
\hline Australia & 1 & 0.85 & 0.00 & Argentina & 0 & 0.85 & 0.00 \\
\hline Austria & 1 & 0.92 & 1.00 & Australia & 1 & 0.85 & 0.00 \\
\hline Belgium & 1 & 0.90 & 0.95 & Austria & 1 & 0.92 & 1.00 \\
\hline Canada & 1 & 0.37 & 0.09 & Belgium & 1 & 0.90 & 0.95 \\
\hline Denmark & 1 & 0.95 & 0.95 & Brazil & 0 & 0.18 & 0.00 \\
\hline Finland & 1 & 0.92 & 0.55 & Bulgaria & 0 & 0.37 & 0.50 \\
\hline Germany & 1 & 1.00 & 0.00 & Canada & 1 & 1.00 & 0.09 \\
\hline Italy & 1 & 0.85 & 0.64 & Chile & 0 & 0.37 & 0.00 \\
\hline Japan & 1 & 0.99 & 0.00 & China & 0 & 0.12 & 0.77 \\
\hline Korea & 1 & 0.36 & 0.14 & Colombia & 0 & 0.19 & 0.00 \\
\hline Mexico & 0 & 0.57 & 0.09 & Czech Republic & 1 & 0.75 & 0.00 \\
\hline Netherlands & 1 & 1.00 & 1.00 & Denmark & 1 & 0.95 & 0.95 \\
\hline Portugal & 1 & 0.80 & 0.59 & Estonia & 1 & 0.99 & 1.00 \\
\hline Spain & 1 & 0.80 & 0.59 & Finland & 1 & 0.92 & 0.55 \\
\hline Sweden & 1 & 0.89 & 0.09 & France & 1 & 0.85 & 0.95 \\
\hline United Kingdom & 1 & 1.00 & 0.00 & Germany & 1 & 1.00 & 0.00 \\
\hline \multirow{33}{*}{ United States } & 1 & 1.00 & 0.00 & Greece & 1 & 0.61 & 0.45 \\
\hline & & & & Hungary & 0 & 0.45 & 0.00 \\
\hline & & & & India & 0 & 0.17 & 0.09 \\
\hline & & & & Indonesia & 0 & 0.84 & 0.09 \\
\hline & & & & Israel & 1 & 0.52 & 0.00 \\
\hline & & & & Italy & 1 & 0.85 & 0.64 \\
\hline & & & & Japan & 1 & 0.99 & 0.00 \\
\hline & & & & Korea & 1 & 0.36 & 0.14 \\
\hline & & & & Latvia & 0 & 0.96 & 0.19 \\
\hline & & & & Lithuania & 0 & 0.99 & 0.82 \\
\hline & & & & Malaysia & 0 & 0.66 & 0.45 \\
\hline & & & & Mexico & 0 & 0.57 & 0.09 \\
\hline & & & & Netherlands & 1 & 1.00 & 1.00 \\
\hline & & & & New Zealand & 1 & 1.00 & 0.00 \\
\hline & & & & Norway & 1 & 0.79 & 0.09 \\
\hline & & & & Pakistan & 0 & 0.16 & 0.23 \\
\hline & & & & Peru & 0 & 0.73 & 0.00 \\
\hline & & & & Philippines & 0 & 0.40 & 0.09 \\
\hline & & & & Poland & 0 & 0.22 & 0.00 \\
\hline & & & & Portugal & 1 & 0.80 & 0.59 \\
\hline & & & & Romania & 0 & 0.31 & 0.00 \\
\hline & & & & Russia & 0 & 0.33 & 0.00 \\
\hline & & & & Slovak Republic & 1 & 0.34 & 0.00 \\
\hline & & & & Slovenia & 1 & 0.68 & 0.29 \\
\hline & & & & South Africa & 0 & 0.15 & 0.00 \\
\hline & & & & Spain & 1 & 0.80 & 0.59 \\
\hline & & & & Sweden & 1 & 0.89 & 0.09 \\
\hline & & & & Thailand & 0 & 0.40 & 0.41 \\
\hline & & & & Turkey & 0 & 0.26 & 0.00 \\
\hline & & & & Ukraine & 0 & 0.15 & 0.38 \\
\hline & & & & United Kingdom & 1 & 1.00 & 0.00 \\
\hline & & & & United States & 1 & 1.00 & 0.00 \\
\hline & & & & Venezuela & 0 & 0.43 & 0.32 \\
\hline
\end{tabular}

Note: We compute the time-series average of the status regarding capital openness and exchange rate regime. 
Table 2. Total cross-border claims and liabilities as a share of GDP

\begin{tabular}{lcc}
\hline & $\begin{array}{c}\text { Total cross-border claims } \\
\text { as a share of GDP }\end{array}$ & $\begin{array}{c}\text { Total cross-border liabilities } \\
\text { as a share of GDP }\end{array}$ \\
\hline Australia & 65.20 & 165.13 \\
Austria & 382.88 & 227.47 \\
Belgium & 571.81 & 441.18 \\
Canada & 88.99 & 66.26 \\
Denmark & 197.52 & 229.40 \\
Finland & 502.87 & 595.53 \\
Germany & 289.92 & 130.79 \\
Italy & 101.95 & 127.21 \\
Japan & 162.92 & 72.29 \\
Korea & 31.03 & 71.46 \\
Mexico & 5.44 & 7.32 \\
Netherlands & 524.19 & 469.70 \\
Portugal & 224.71 & 184.77 \\
Spain & 135.20 & 171.35 \\
Sweden & 278.91 & 169.49 \\
United Kingdom & 643.95 & 379.29 \\
United States & 63.55 & 49.65 \\
\hline
\end{tabular}

Note: Total cross-border claims and liabilities as a share of the domestic GDP in 2010Q4 under locational banking statistics with the residency principle. 
Table 3. Baseline estimation results from a dynamic framework

A) Results using RZ spending shocks

\begin{tabular}{|c|c|c|c|c|c|c|c|c|}
\hline & $\mathrm{h}=0$ & $\mathrm{~h}=1$ & $\mathrm{~h}=2$ & $h=3$ & $\mathrm{~h}=4$ & $\mathrm{~h}=5$ & $\mathrm{~h}=6$ & $\mathrm{~h}=7$ \\
\hline $\begin{array}{l}\text { Log cross-border } \\
\text { claims }(-1)\end{array}$ & $\begin{array}{c}-20.669 * * * \\
(2.902)\end{array}$ & $\begin{array}{c}-25.949 * * * \\
(3.078)\end{array}$ & $\begin{array}{c}-30.738 * * * \\
(3.534)\end{array}$ & $\begin{array}{c}-25.116^{* * *} \\
(2.978)\end{array}$ & $\begin{array}{c}-27.173 * * * \\
(3.610)\end{array}$ & $\begin{array}{c}-34.676^{* * *} \\
(3.999)\end{array}$ & $\begin{array}{c}-39.455 * * * \\
(3.971)\end{array}$ & $\begin{array}{c}-34.739 * * * \\
(3.570)\end{array}$ \\
\hline $\begin{array}{l}\text { Log cross-border } \\
\text { claims }(-2)\end{array}$ & $\begin{array}{c}10.430^{* * * *} \\
(2.501)\end{array}$ & $\begin{array}{l}8.650 * * \\
(3.668)\end{array}$ & $\begin{array}{c}17.530 * * * \\
(3.903)\end{array}$ & $\begin{array}{c}12.175^{* * * *} \\
(3.955)\end{array}$ & $\begin{array}{l}9.892 * * \\
(4.129)\end{array}$ & $\begin{array}{c}7.984 \\
(4.983)\end{array}$ & $\begin{array}{c}18.373 * * * \\
(4.966)\end{array}$ & $\begin{array}{c}10.541 * * \\
(4.048)\end{array}$ \\
\hline Fiscal shock & $\begin{array}{c}2.581 * * * \\
(0.485)\end{array}$ & $\begin{array}{c}2.272 * * * \\
(0.585)\end{array}$ & $\begin{array}{c}3.271 * * * \\
(0.712)\end{array}$ & $\begin{array}{c}1.895 \\
(1.187)\end{array}$ & $\begin{array}{c}1.156 \\
(1.521)\end{array}$ & $\begin{array}{c}0.836 \\
(1.439)\end{array}$ & $\begin{array}{c}1.731 \\
(2.484)\end{array}$ & $\begin{array}{c}0.783 \\
(2.407)\end{array}$ \\
\hline Fiscal shock (-1) & $\begin{array}{c}0.874 \\
(0.564)\end{array}$ & $\begin{array}{l}1.617 * * \\
(0.659)\end{array}$ & $\begin{array}{l}-0.005 \\
(1.019)\end{array}$ & $\begin{array}{l}-0.481 \\
(1.525)\end{array}$ & $\begin{array}{l}-0.861 \\
(1.521)\end{array}$ & $\begin{array}{l}0.208 \\
(2.403)\end{array}$ & $\begin{array}{c}0.421 \\
(1.921)\end{array}$ & $\begin{array}{c}0.703 \\
(2.076)\end{array}$ \\
\hline Fiscal shock (-2) & $\begin{array}{c}0.660 \\
(0.493)\end{array}$ & $\begin{array}{l}-0.381 \\
(0.535)\end{array}$ & $\begin{array}{l}-1.311 \\
(1.036)\end{array}$ & $\begin{array}{l}-1.448 \\
(1.314)\end{array}$ & $\begin{array}{c}-1.02 \\
(2.048)\end{array}$ & $\begin{array}{l}-1.415 \\
(1.829)\end{array}$ & $\begin{array}{l}-0.123 \\
(2.170)\end{array}$ & $\begin{array}{l}-0.943 \\
(2.145)\end{array}$ \\
\hline $\begin{array}{l}\text { Recipient GDP } \\
\text { growth }\end{array}$ & $\begin{array}{c}0.765 * * \\
(0.307)\end{array}$ & $\begin{array}{c}0.544 \\
(0.451)\end{array}$ & $\begin{array}{l}1.083 * * \\
(0.472)\end{array}$ & $\begin{array}{l}1.416 * * \\
(0.626)\end{array}$ & $\begin{array}{l}1.393 * * \\
(0.684)\end{array}$ & $\begin{array}{c}2.020 * * * \\
(0.755)\end{array}$ & $\begin{array}{l}2.249 * * \\
(0.859)\end{array}$ & $\begin{array}{l}1.700^{*} \\
(0.917)\end{array}$ \\
\hline $\begin{array}{l}\text { Recipient GDP } \\
\text { growth }(-1)\end{array}$ & $\begin{array}{l}-0.051 \\
(0.331)\end{array}$ & $\begin{array}{c}0.521 \\
(0.373)\end{array}$ & $\begin{array}{c}0.638 \\
(0.506)\end{array}$ & $\begin{array}{c}0.428 \\
(0.543)\end{array}$ & $\begin{array}{l}1.218^{*} \\
(0.661)\end{array}$ & $\begin{array}{l}1.487 * \\
(0.755)\end{array}$ & $\begin{array}{c}0.942 \\
(0.822)\end{array}$ & $\begin{array}{l}1.357^{*} \\
(0.788)\end{array}$ \\
\hline $\begin{array}{l}\text { Recipient GDP } \\
\text { growth }(-2)\end{array}$ & $\begin{array}{c}0.411 \\
(0.277)\end{array}$ & $\begin{array}{l}0.970 * * \\
(0.374)\end{array}$ & $\begin{array}{c}0.745 \\
(0.497)\end{array}$ & $\begin{array}{l}1.322 * * \\
(0.627)\end{array}$ & $\begin{array}{l}1.577 * * \\
(0.691)\end{array}$ & $\begin{array}{c}1.077 \\
(0.721)\end{array}$ & $\begin{array}{c}1.216 \\
(0.803)\end{array}$ & $\begin{array}{l}1.745^{* *} \\
(0.740)\end{array}$ \\
\hline Recipient interest rate & $\begin{array}{c}-0.074 * * * \\
(0.022)\end{array}$ & $\begin{array}{c}-0.095 * * * \\
(0.031)\end{array}$ & $\begin{array}{c}-0.122 * * * \\
(0.044)\end{array}$ & $\begin{array}{c}-0.132 * * \\
(0.055)\end{array}$ & $\begin{array}{c}-0.184 * * * \\
(0.063)\end{array}$ & $\begin{array}{c}-0.231 * * * \\
(0.074)\end{array}$ & $\begin{array}{c}-0.323^{* * *} \\
(0.112)\end{array}$ & $\begin{array}{c}-0.356^{* *} \\
(0.144)\end{array}$ \\
\hline $\begin{array}{l}\text { Recipient interest rate } \\
(-1)\end{array}$ & $\begin{array}{c}-0.000 * * \\
(0.000)\end{array}$ & $\begin{array}{c}-0.002 * * * \\
(0.000)\end{array}$ & $\begin{array}{c}-0.001 * * * \\
(0.000)\end{array}$ & $\begin{array}{c}-0.002 * * * \\
(0.000)\end{array}$ & $\begin{array}{c}0.000 \\
(0.000)\end{array}$ & $\begin{array}{c}0.000 \\
(0.000)\end{array}$ & $\begin{array}{l}-0.001 \\
(0.001)\end{array}$ & $\begin{array}{c}0.000 \\
(0.001)\end{array}$ \\
\hline $\begin{array}{l}\text { Recipient interest rate } \\
(-2)\end{array}$ & $\begin{array}{c}-0.002 * * * \\
(0.000)\end{array}$ & $\begin{array}{c}-0.001 * * * \\
(0.000)\end{array}$ & $\begin{array}{c}-0.002^{* * *} \\
(0.000)\end{array}$ & $\begin{array}{c}0.000 \\
(0.000) \\
\end{array}$ & $\begin{array}{l}-0.001 \\
(0.000) \\
\end{array}$ & $\begin{array}{c}-0.001 * * * \\
(0.000)\end{array}$ & $\begin{array}{c}0.000 \\
(0.000) \\
\end{array}$ & $\begin{array}{c}-0.001 * \\
(0.001) \\
\end{array}$ \\
\hline Obs & 3,216 & 3,173 & 3,133 & 3,091 & 3,048 & 3,005 & 2,962 & 2,921 \\
\hline R-squared & 0.082 & 0.095 & 0.117 & 0.109 & 0.132 & 0.156 & 0.191 & 0.207 \\
\hline $\begin{array}{l}\text { Recipient country } \\
\text { fixed effect }\end{array}$ & Yes & Yes & Yes & Yes & Yes & Yes & Yes & Yes \\
\hline
\end{tabular}


B) Results using RR revenue shocks

\begin{tabular}{|c|c|c|c|c|c|c|c|c|}
\hline & $\mathrm{h}=0$ & $\mathrm{~h}=1$ & $\mathrm{~h}=2$ & $\mathrm{~h}=3$ & $\mathrm{~h}=4$ & $\mathrm{~h}=5$ & $\mathrm{~h}=6$ & $\mathrm{~h}=7$ \\
\hline $\begin{array}{l}\text { Log cross-border } \\
\text { claims }(-1)\end{array}$ & $\begin{array}{c}-23.382 * * * \\
(2.909)\end{array}$ & $\begin{array}{c}-20.951 * * * \\
(2.718)\end{array}$ & $\begin{array}{c}-30.149 * * * \\
(4.011)\end{array}$ & $\begin{array}{c}-23.419 * * * \\
(3.133)\end{array}$ & $\begin{array}{c}-26.078 * * * \\
(3.591)\end{array}$ & $\begin{array}{c}-30.803 * * * \\
(4.245)\end{array}$ & $\begin{array}{c}-33.234 * * * \\
(3.452)\end{array}$ & $\begin{array}{c}-26.776^{* * *} \\
(3.752)\end{array}$ \\
\hline $\begin{array}{l}\text { Log cross-border } \\
\text { claims }(-2)\end{array}$ & $\begin{array}{c}14.402 * * * \\
(2.881)\end{array}$ & $\begin{array}{l}5.152 * * \\
(2.403)\end{array}$ & $\begin{array}{c}19.838 * * * \\
(3.862)\end{array}$ & $\begin{array}{c}14.611 * * * \\
(3.841)\end{array}$ & $\begin{array}{c}14.988 * * * \\
(4.229)\end{array}$ & $\begin{array}{l}8.822 * \\
(5.154)\end{array}$ & $\begin{array}{c}16.238 * * * \\
(3.618)\end{array}$ & $\begin{array}{c}3.832 \\
(5.314)\end{array}$ \\
\hline Fiscal shock & $\begin{array}{l}4.068 * * \\
(1.569)\end{array}$ & $\begin{array}{c}3.400 \\
(3.200)\end{array}$ & $\begin{array}{l}5.151^{*} \\
(3.102)\end{array}$ & $\begin{array}{c}5.577 \\
(4.556)\end{array}$ & $\begin{array}{l}5.588^{*} \\
(3.021)\end{array}$ & $\begin{array}{c}1.291 \\
(3.799)\end{array}$ & $\begin{array}{c}2.674 \\
(3.880)\end{array}$ & $\begin{array}{c}2.869 \\
(6.439)\end{array}$ \\
\hline Fiscal shock $(-1)$ & $\begin{array}{c}2.449 \\
(2.634)\end{array}$ & $\begin{array}{l}2.698 \\
(2.757)\end{array}$ & $\begin{array}{l}2.495 \\
(3.954)\end{array}$ & $\begin{array}{c}0.642 \\
(2.580)\end{array}$ & $\begin{array}{l}-0.023 \\
(2.826)\end{array}$ & $\begin{array}{l}-0.554 \\
(3.333)\end{array}$ & $\begin{array}{l}-1.513 \\
(5.326)\end{array}$ & $\begin{array}{c}0.487 \\
(5.909)\end{array}$ \\
\hline Fiscal shock (-2) & $\begin{array}{c}1.203 \\
(2.044)\end{array}$ & $\begin{array}{c}1.256 \\
(2.157)\end{array}$ & $\begin{array}{l}-1.553 \\
(2.560)\end{array}$ & $\begin{array}{c}0.168 \\
(2.740)\end{array}$ & $\begin{array}{l}-2.819 \\
(2.690)\end{array}$ & $\begin{array}{c}0.26 \\
(4.902)\end{array}$ & $\begin{array}{l}-1.956 \\
(4.540)\end{array}$ & $\begin{array}{l}-3.283 \\
(5.322)\end{array}$ \\
\hline Recipient GDP growth & $\begin{array}{c}0.184 \\
(0.303)\end{array}$ & $\begin{array}{l}-0.368 \\
(0.496)\end{array}$ & $\begin{array}{c}0.306 \\
(0.451)\end{array}$ & $\begin{array}{c}0.792 \\
(0.536)\end{array}$ & $\begin{array}{c}0.649 \\
(0.615)\end{array}$ & $\begin{array}{c}1.018 \\
(0.663)\end{array}$ & $\begin{array}{l}1.459 * * \\
(0.734)\end{array}$ & $\begin{array}{c}1.083 \\
(0.812)\end{array}$ \\
\hline $\begin{array}{l}\text { Recipient GDP growth } \\
(-1)\end{array}$ & $\begin{array}{l}-0.263 \\
(0.339)\end{array}$ & $\begin{array}{c}0.195 \\
(0.386)\end{array}$ & $\begin{array}{c}0.462 \\
(0.480)\end{array}$ & $\begin{array}{c}0.365 \\
(0.458)\end{array}$ & $\begin{array}{l}0.863^{*} \\
(0.497)\end{array}$ & $\begin{array}{l}1.275 * * \\
(0.565)\end{array}$ & $\begin{array}{l}0.959^{*} \\
(0.572)\end{array}$ & $\begin{array}{c}1.068 \\
(0.691)\end{array}$ \\
\hline $\begin{array}{l}\text { Recipient GDP growth } \\
(-2)\end{array}$ & $\begin{array}{c}0.477 \\
(0.295)\end{array}$ & $\begin{array}{l}0.906 * * \\
(0.392)\end{array}$ & $\begin{array}{c}0.846 \\
(0.519)\end{array}$ & $\begin{array}{l}1.237 * * \\
(0.538)\end{array}$ & $\begin{array}{c}1.817 * * * \\
(0.549)\end{array}$ & $\begin{array}{c}1.493 * * * \\
(0.549)\end{array}$ & $\begin{array}{l}1.541 * * \\
(0.636)\end{array}$ & $\begin{array}{c}2.194 * * * \\
(0.614)\end{array}$ \\
\hline Recipient interest rate & $\begin{array}{c}-0.082 * * * \\
(0.025)\end{array}$ & $\begin{array}{c}-0.104 * * * \\
(0.039)\end{array}$ & $\begin{array}{c}-0.127 * * * \\
(0.048)\end{array}$ & $\begin{array}{c}-0.132 * * \\
(0.054)\end{array}$ & $\begin{array}{c}-0.199 * * * \\
(0.076)\end{array}$ & $\begin{array}{c}-0.236^{* * *} \\
(0.088)\end{array}$ & $\begin{array}{c}-0.322 * * \\
(0.131)\end{array}$ & $\begin{array}{c}-0.367 * * \\
(0.175)\end{array}$ \\
\hline $\begin{array}{l}\text { Recipient interest rate } \\
(-1)\end{array}$ & $\begin{array}{c}-0.000 * * \\
(0.000)\end{array}$ & $\begin{array}{c}-0.002 * * * \\
(0.000)\end{array}$ & $\begin{array}{c}-0.001 * * * \\
(0.000)\end{array}$ & $\begin{array}{c}-0.001 * * * \\
(0.000)\end{array}$ & $\begin{array}{c}0.000 \\
(0.000)\end{array}$ & $\begin{array}{c}0.000 \\
(0.000)\end{array}$ & $\begin{array}{c}0.000 \\
(0.001)\end{array}$ & $\begin{array}{c}0.000 \\
(0.001)\end{array}$ \\
\hline $\begin{array}{l}\text { Recipient interest rate } \\
(-2)\end{array}$ & $\begin{array}{c}-0.001 * * * \\
(0.000)\end{array}$ & $\begin{array}{c}-0.001 * * * \\
(0.000)\end{array}$ & $\begin{array}{c}-0.001 * * * \\
(0.000\end{array}$ & $\begin{array}{c}0.000 \\
(0.000 \\
\end{array}$ & $\begin{array}{c}0.000 \\
(0.000)\end{array}$ & $\begin{array}{c}0.000 \\
(0.000)\end{array}$ & $\begin{array}{c}0.000 \\
(0.000)\end{array}$ & $\begin{array}{c}0.000 \\
(0.001) \\
\end{array}$ \\
\hline $\begin{array}{l}\text { Obs } \\
\text { R-squared }\end{array}$ & $\begin{array}{l}2,746 \\
0.085\end{array}$ & $\begin{array}{l}2,747 \\
0.075\end{array}$ & $\begin{array}{l}2,749 \\
0.104\end{array}$ & $\begin{array}{l}2,747 \\
0.098\end{array}$ & $\begin{array}{l}2,745 \\
0109\end{array}$ & $\begin{array}{l}2,744 \\
0,123\end{array}$ & $\begin{array}{l}2,738 \\
0,152\end{array}$ & $\begin{array}{l}2,741 \\
0,148\end{array}$ \\
\hline $\begin{array}{l}\text { Recipient country fixed } \\
\text { effect }\end{array}$ & Yes & Yes & Yes & Yes & Yes & Yes & Yes & Yes \\
\hline
\end{tabular}


Table 4. Summary of exogenous spending shocks in 16 OECD countries: 1990-2010

\begin{tabular}{lcccc}
\hline Source country & Mean & Standard deviation & $\begin{array}{c}\text { Correlation with U.S. } \\
\text { shocks }\end{array}$ & Obs \\
\hline Australia & -0.004 & 0.189 & 0.083 & 29 \\
Austria & 0.001 & 0.240 & -0.012 & 17 \\
Belgium & 0.002 & 0.089 & 0.237 & 29 \\
Canada & -0.043 & 0.174 & -0.059 & 41 \\
Denmark & 0.001 & 0.185 & 0.413 & 28 \\
Finland & 0.001 & 0.214 & 0.349 & 29 \\
Germany & 0.013 & 0.186 & -0.346 & 41 \\
Italy & 0.010 & 0.124 & 0.348 & 40 \\
Japan & 0.010 & 0.123 & -0.047 & 41 \\
Korea & -0.009 & 0.206 & 0.029 & 28 \\
Mexico & -0.008 & 0.279 & -0.144 & 29 \\
Netherlands & -0.002 & 0.214 & 0.043 & 29 \\
Portugal & -0.003 & 0.144 & -0.252 & 29 \\
Spain & -0.004 & 0.163 & -0.056 & 29 \\
Sweden & 0.000 & 0.331 & -0.045 & 29 \\
United Kingdom & -0.014 & 0.241 & -0.445 & 1 \\
United States & 0.003 & 0.132 & 41 \\
\hline Note: & & & 41 \\
\hline
\end{tabular}

Note: The exogenous spending shocks are taken from Auerbach and Gorodnichencko (2012b) and normalized by the lagged nominal GDP. 
Figure 1. Total U.S. cross-border bank claims: raw stock vs. exchange rate-adjusted stock

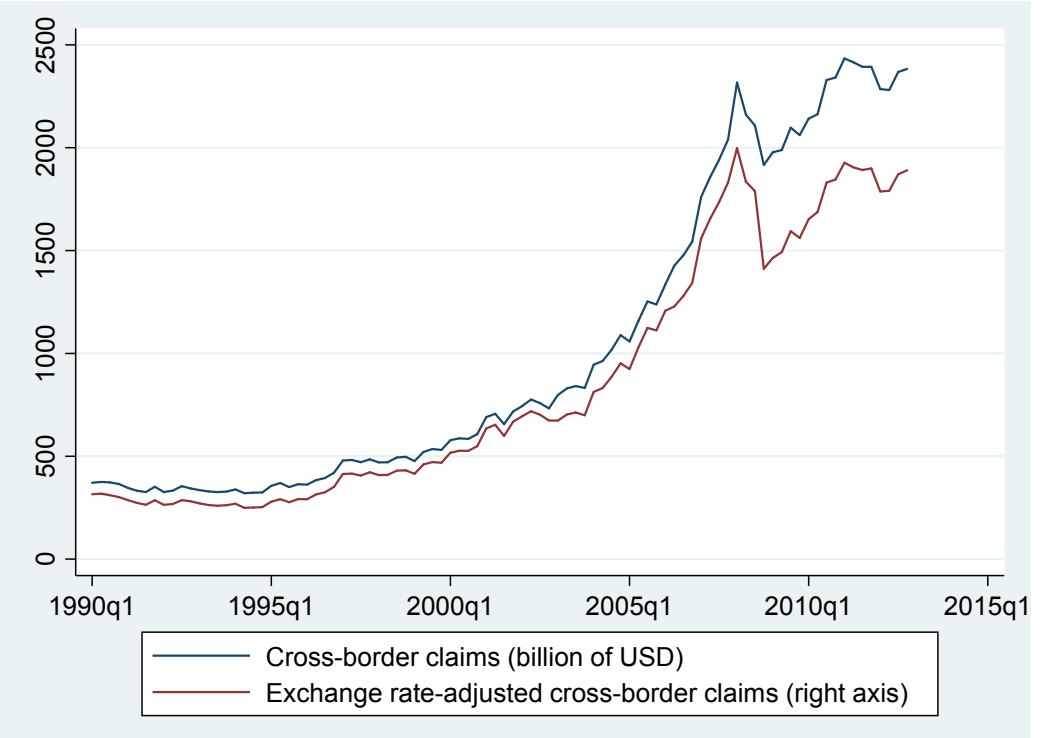

Note: The left panel shows total U.S. cross-border bank claims (exchange rate-unadjusted) and the right panel shows exchange rate-adjusted U.S. cross-border bank claims from 1990Q1 to 2012Q4. 
Figure 2. Exchange-rate adjusted U.S. cross-border bank claims to individual countries
a) country A
b) country B

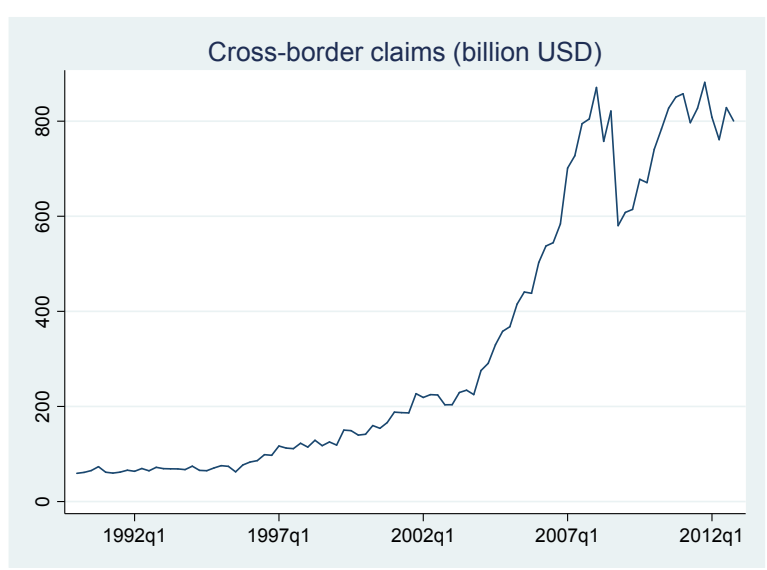

c) country $\mathrm{C}$

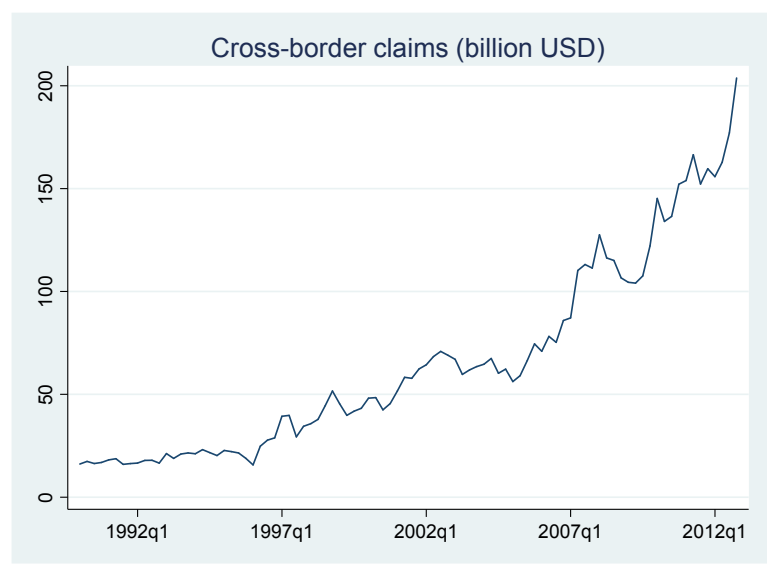

e) country E

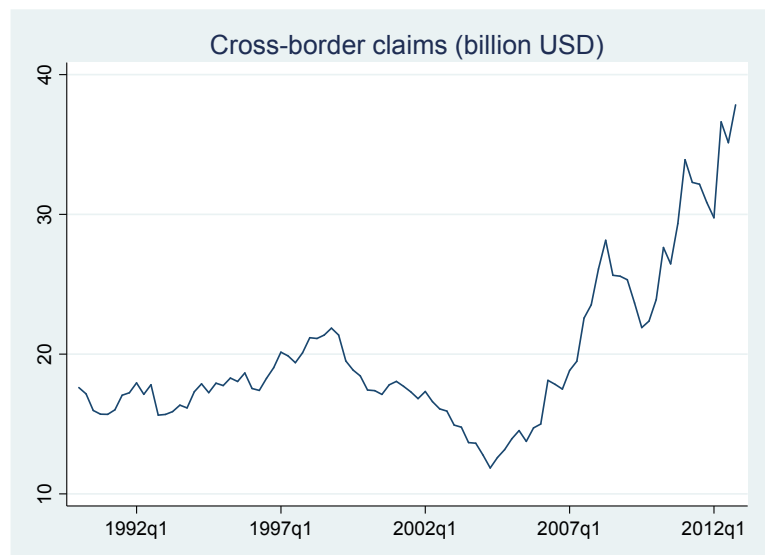

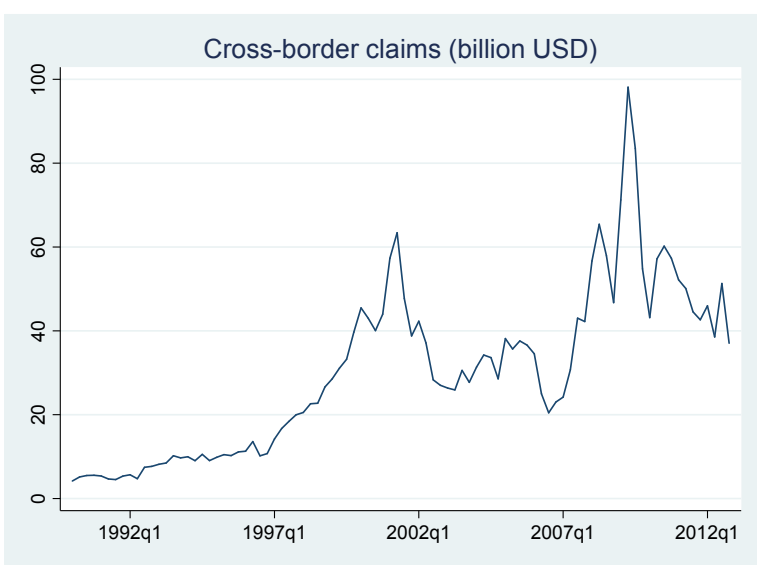

d) country D

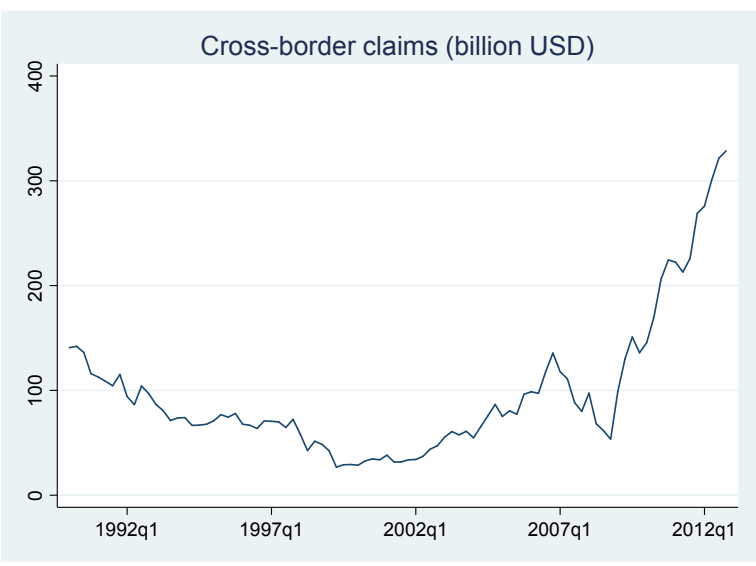

f) country F

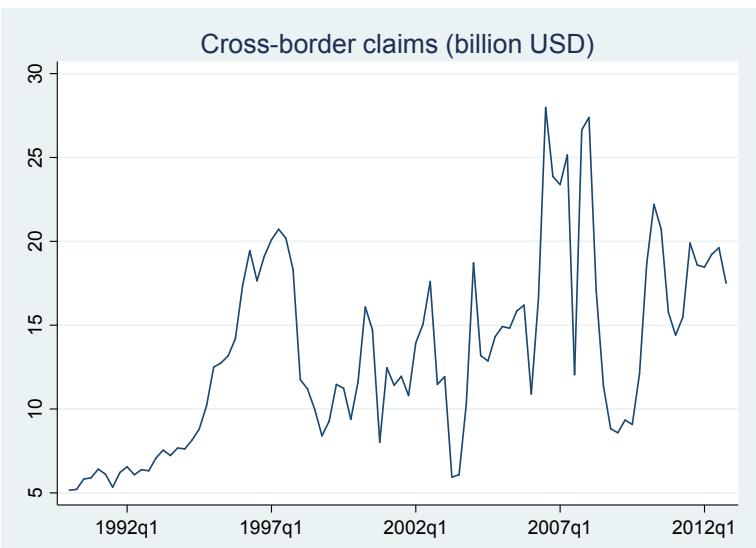

Note: Each graph shows bilateral exchange rate-adjusted cross-border claims between the U.S. and the corresponding recipient country from 1990Q1 to 2012Q4. 
Figure 3. Time series of exogenous fiscal shocks in the U.S. (\% of GDP)

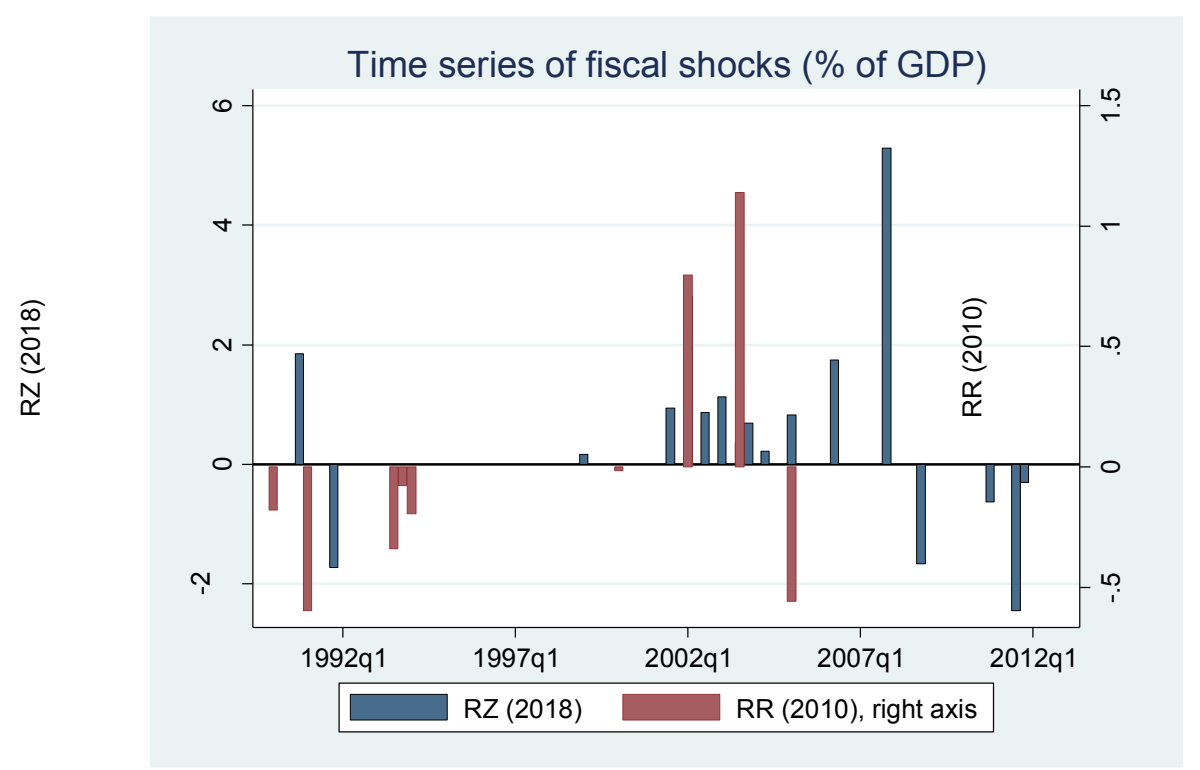

Note: The left axis denotes the time series of exogenous government spending shocks from Ramey and Zubairy (2018), while the right axis denotes the time series of exogenous tax shocks from Romer and Romer (2010). Both measures are in percentage of GDP, and the tax shocks from Romer and Romer (2010) are available until 2007 4.

Figure 4. Estimated effect of a U.S. expansionary fiscal policy shock (1 percent of GDP) on crossborder bank lending

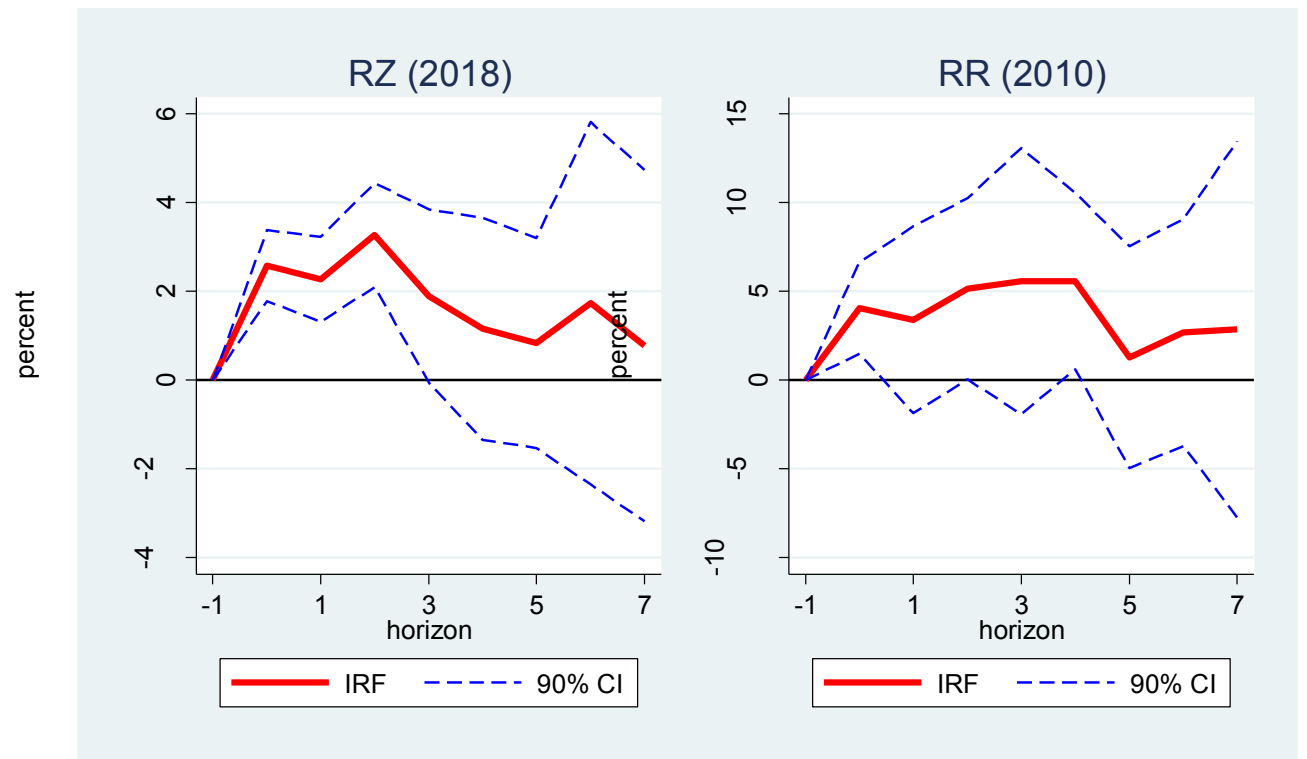

Note: The left panel shows the response of cross-border bank lending to a U.S. expansionary fiscal policy shock (1 percent of GDP) using exogenous government spending shocks from Ramey and Zubairy (2018), while the right panel shows the response to exogenous tax shocks from Romer and Romer (2010). Horizon $h=0$ captures the impact of the shock, and the units are in percentage. 
Figure 5. Transmission channel of U.S. fiscal shocks

A) Response of the real effective exchange rate to the fiscal shock
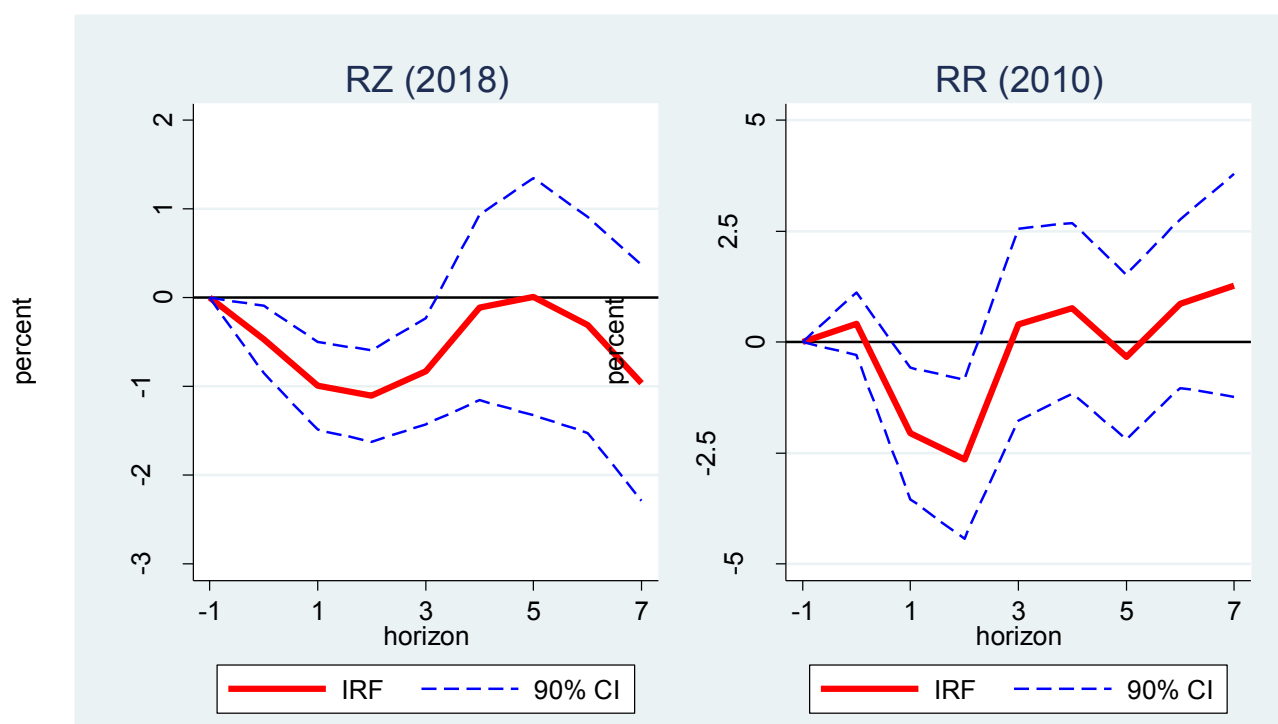

Note: The left panel shows the response of the real effective exchange rate to a U.S. expansionary fiscal policy shock (1 percent of GDP) using exogenous government spending shocks from Ramey and Zubairy (2018), while the right panel shows the response to exogenous tax shocks from Romer and Romer (2010). Horizon $h=0$ captures the impact of the shock, and the units are in percentage.

B) Response of the real interest rate to the fiscal shock

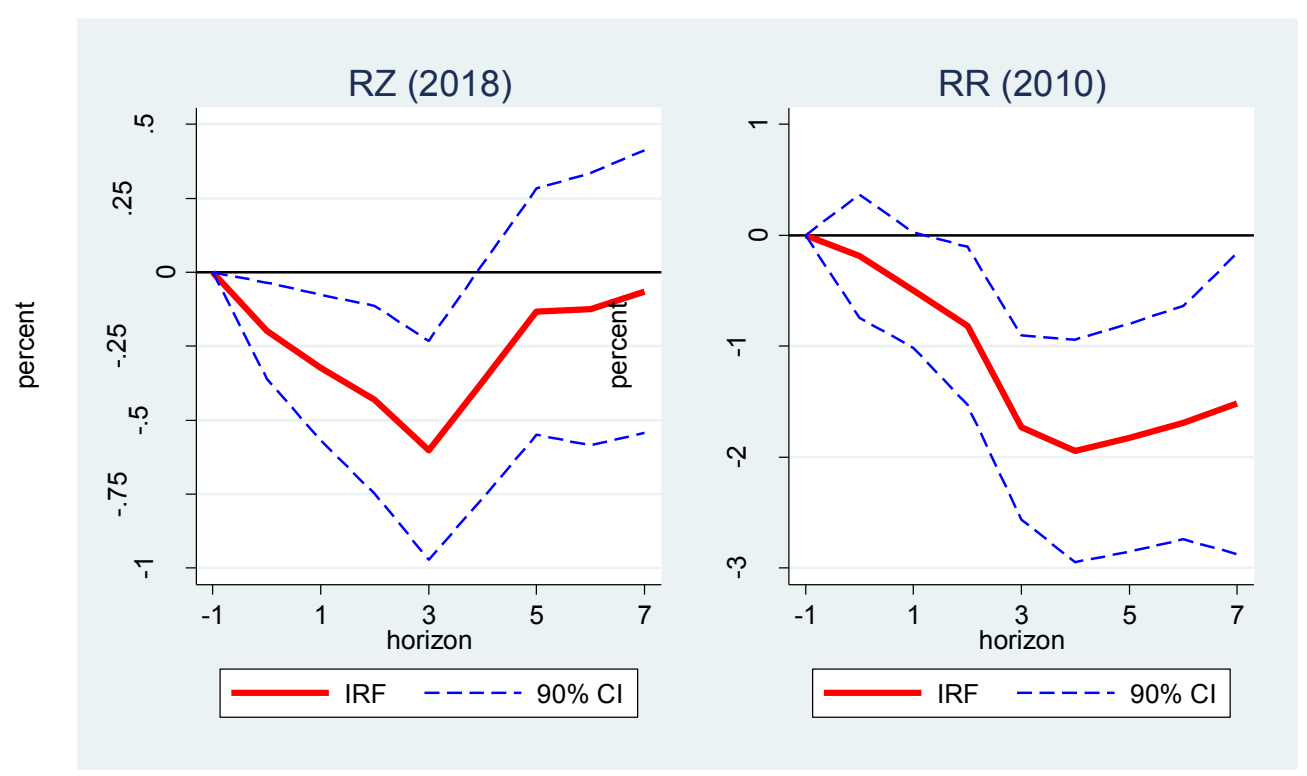

Note: The left panel shows the response of the real interest rate to a U.S. expansionary fiscal policy shock (1 percent of GDP) using exogenous government spending shocks from Ramey and Zubairy (2018), while the right panel shows the response to exogenous tax shocks from Romer and Romer (2010). Horizon $h=0$ captures the impact of the shock, and the units are in percentage. 
Figure 6. Estimated effect of a U.S. expansionary fiscal policy shock (1 percent of GDP) on crossborder bank lending after controlling for monetary policy shocks

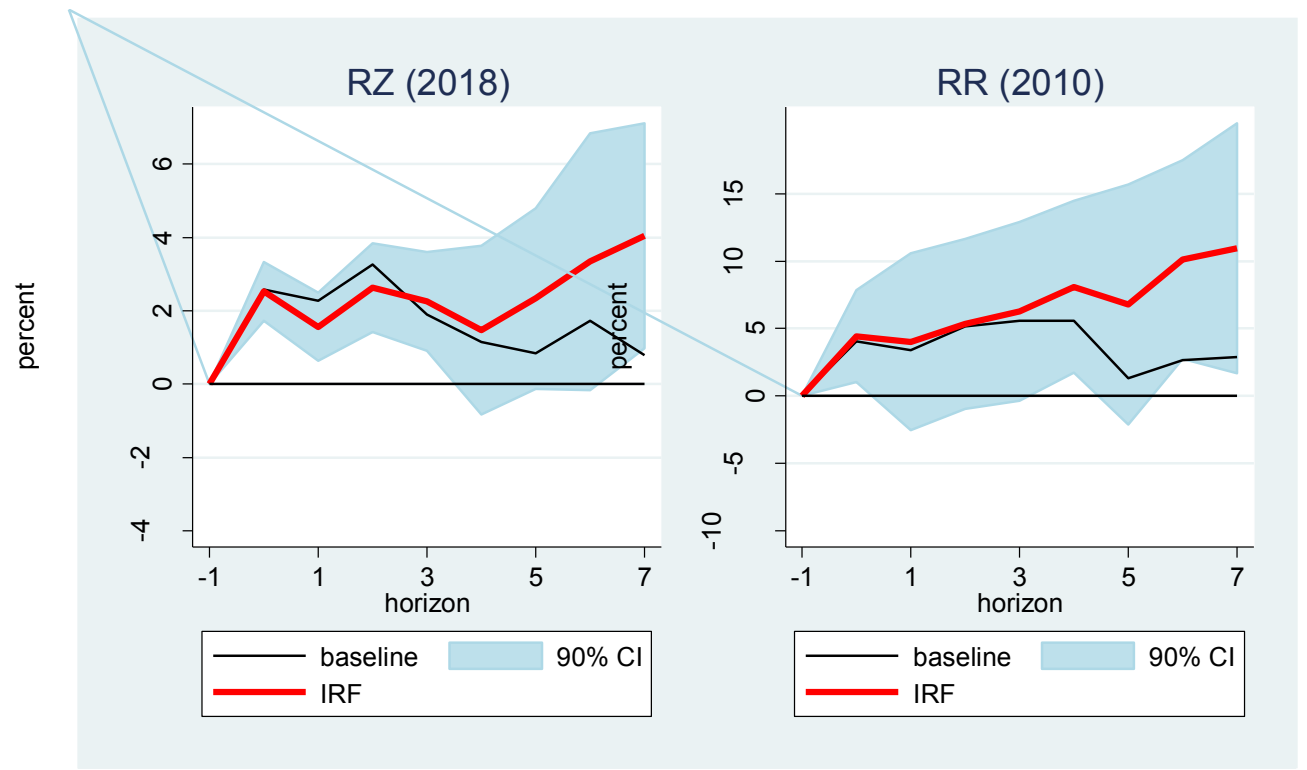

Note: The left panel shows the response of cross-border bank lending to a U.S. expansionary fiscal policy shock (1 percent of GDP) using exogenous government spending shocks from Ramey and Zubairy (2018) after controlling for monetary policy shocks constructed by Coibion (2012) who extends the narrative approach by Romer and Romer (2004), while the right panel shows the response to exogenous tax shocks from Romer and Romer (2010). Horizon $h=0$ captures the impact of the shock, and the units are in percentage.

Figure 7. Forecast variance error decomposition of cross-border bank lending

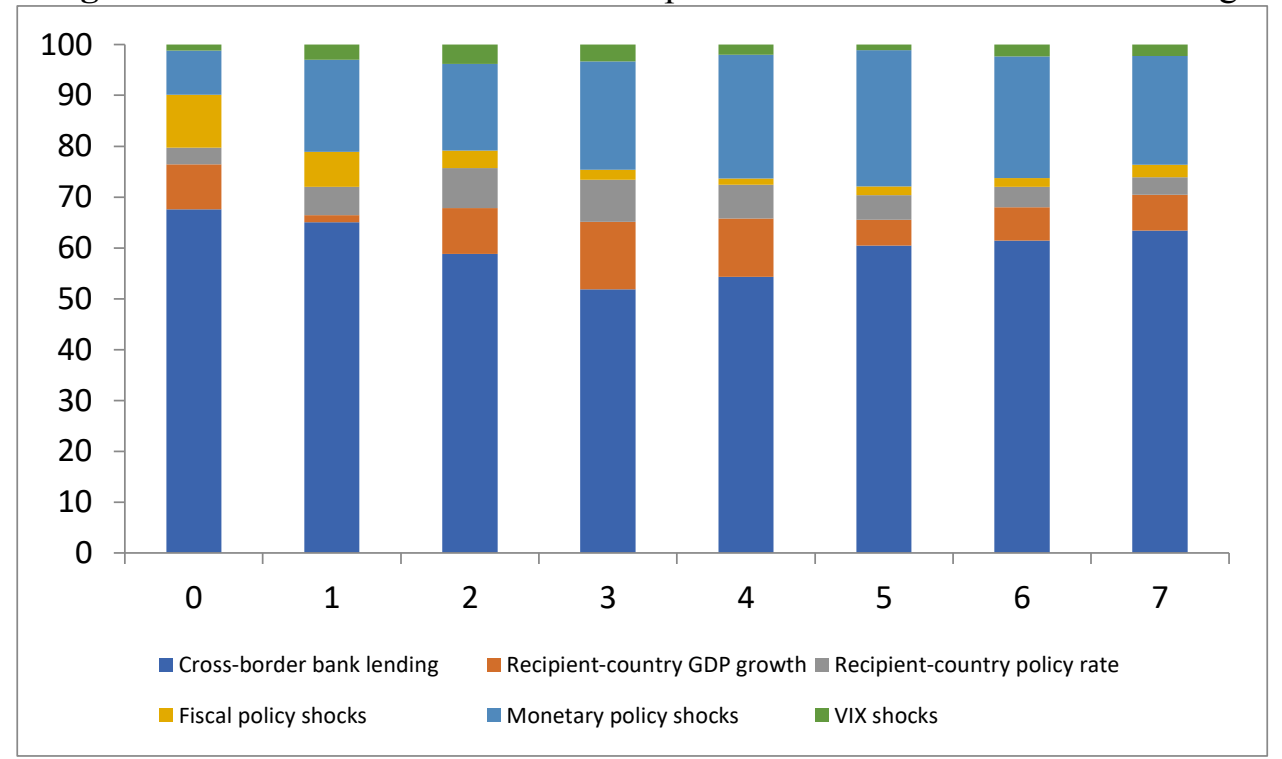

Note: Each horizon corresponds to the forecasting horizon estimated in the augmented model with monetary policy shocks and VIX shocks. 
Figure 8. Estimated effect of a U.S. expansionary fiscal policy shock (1 percent of GDP) on crossborder bank net lending
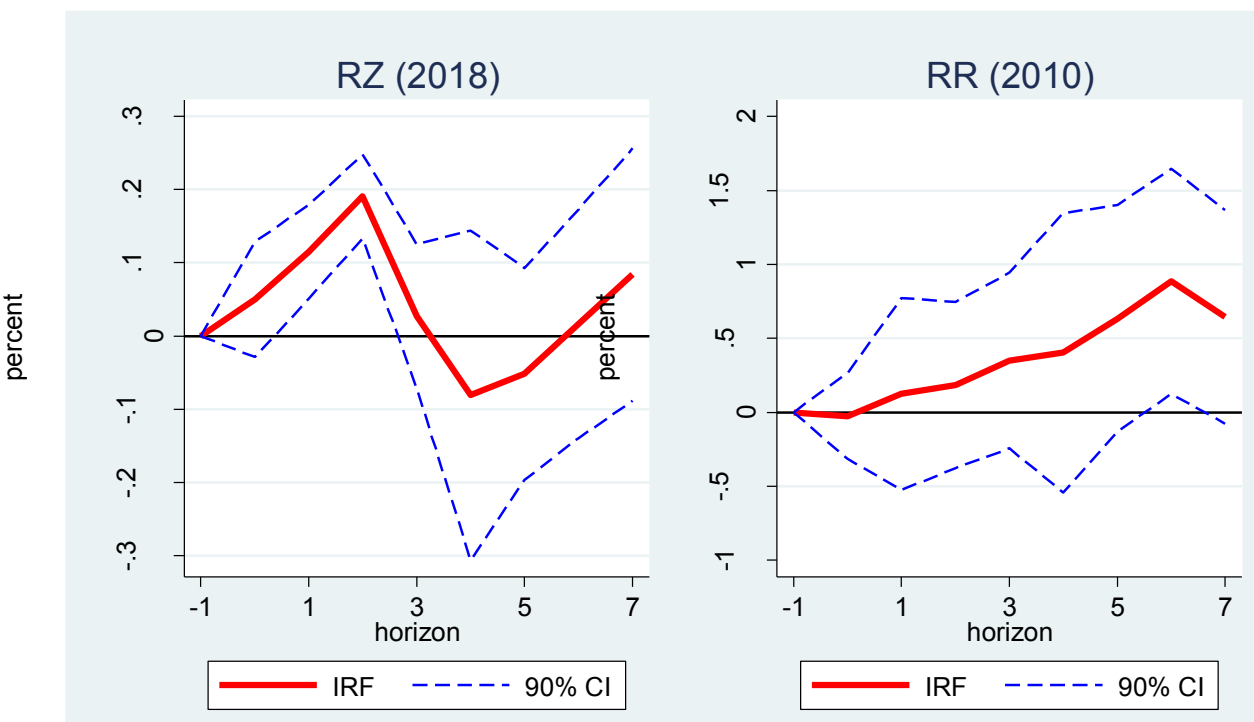

Note: The left panel shows the response of cross-border bank net lending to a U.S. expansionary fiscal policy shock (1 percent of GDP) using exogenous government spending shocks from Ramey and Zubairy (2018), while the right panel shows the response to exogenous tax shocks from Romer and Romer (2010). Horizon $h=0$ captures the impact of the shock, and the units are in percentage.

Figure 9. NBER recession dates and the weight on a recession regime

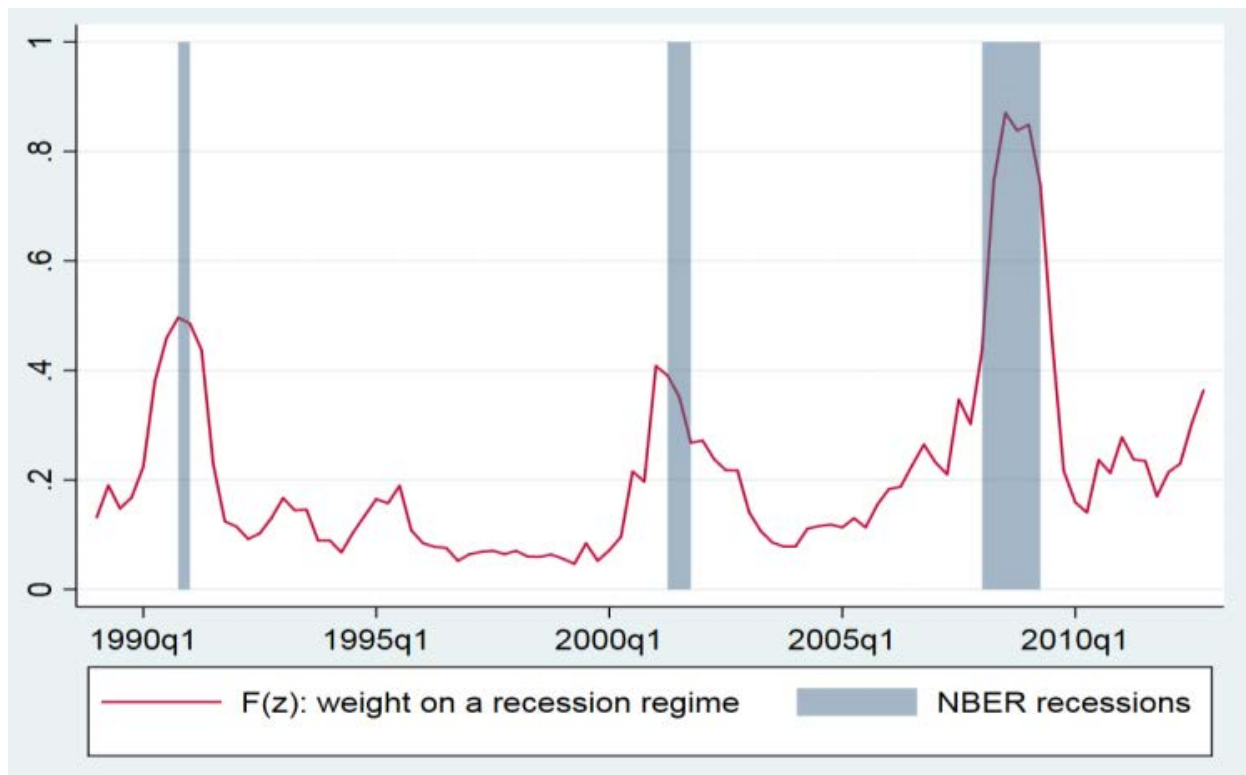

Note: The shaded areas indicate NBER recessions, while the red solid line denotes the weight on a recession regime. 
Figure 10. Estimated effect of a U.S. expansionary fiscal policy shock (1 percent of GDP) on crossborder bank lending: expansions vs. recessions

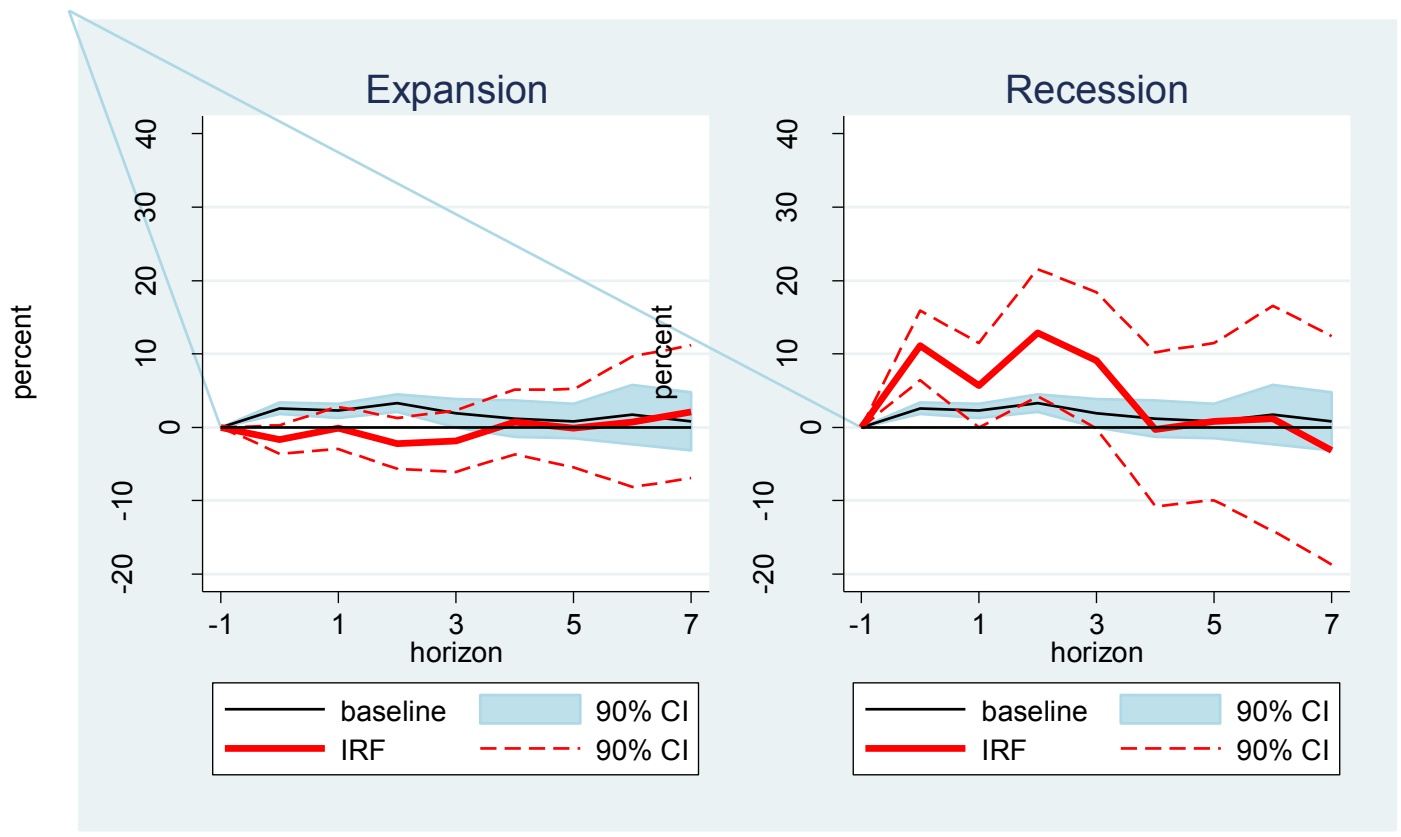

Note: The left (right) panel shows the response of cross-border bank lending to exogenous government spending shocks from Ramey and Zubairy (2018) during expansions (recessions). Horizon $h=0$ captures the impact of the shock, and the units are in percentage.

Figure 11. Estimated effect of a U.S. expansionary fiscal policy shock (1 percent of GDP) on crossborder bank lending: expansionary vs. contractionary shocks

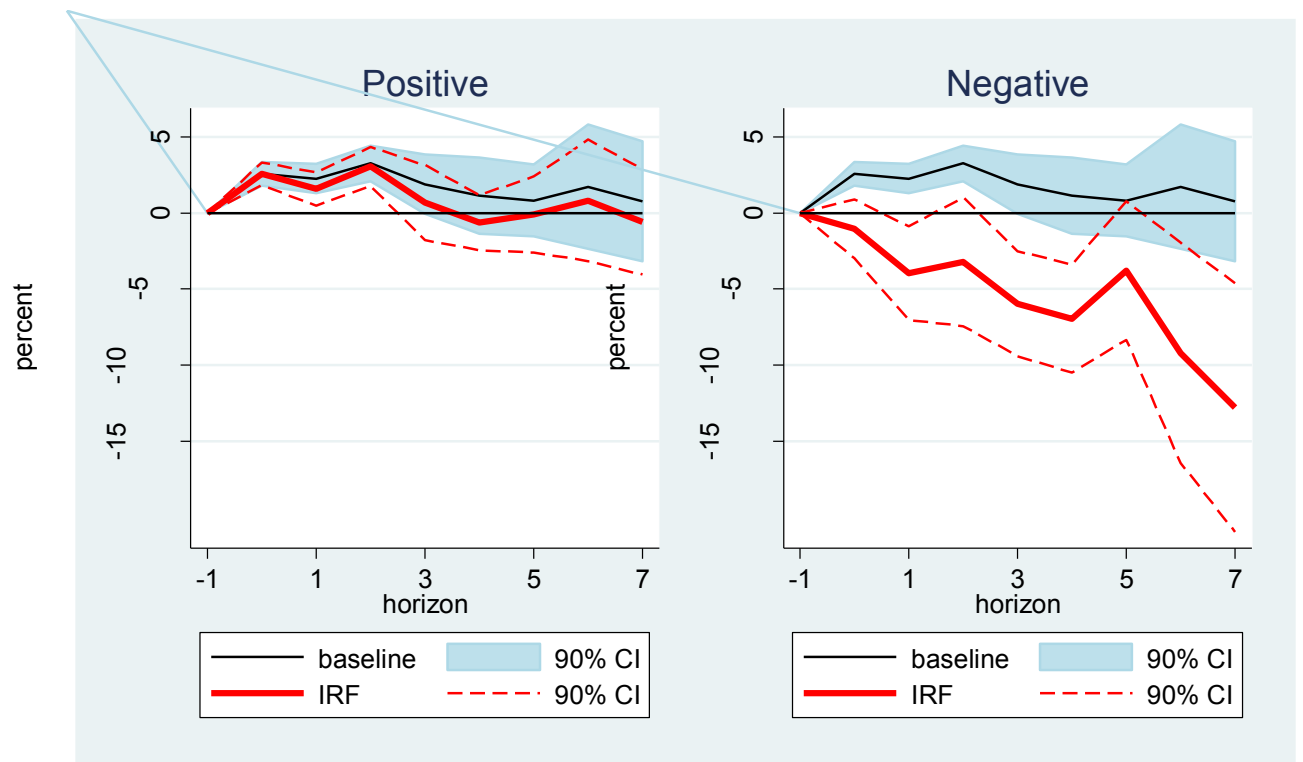

Note: The left (right) panel shows the response of cross-border bank lending to expansionary (contractionary) exogenous government spending shocks from Ramey and Zubairy (2018). Horizon $h=0$ captures the impact of the shock, and the units are in percentage. The sign of the response to contractionary shocks is adjusted so that the response is negative in this case. 
Figure 12. Estimated effect of a U.S. expansionary fiscal policy shock (1 percent of GDP) on crossborder bank lending: pegged vs. non-pegged recipients

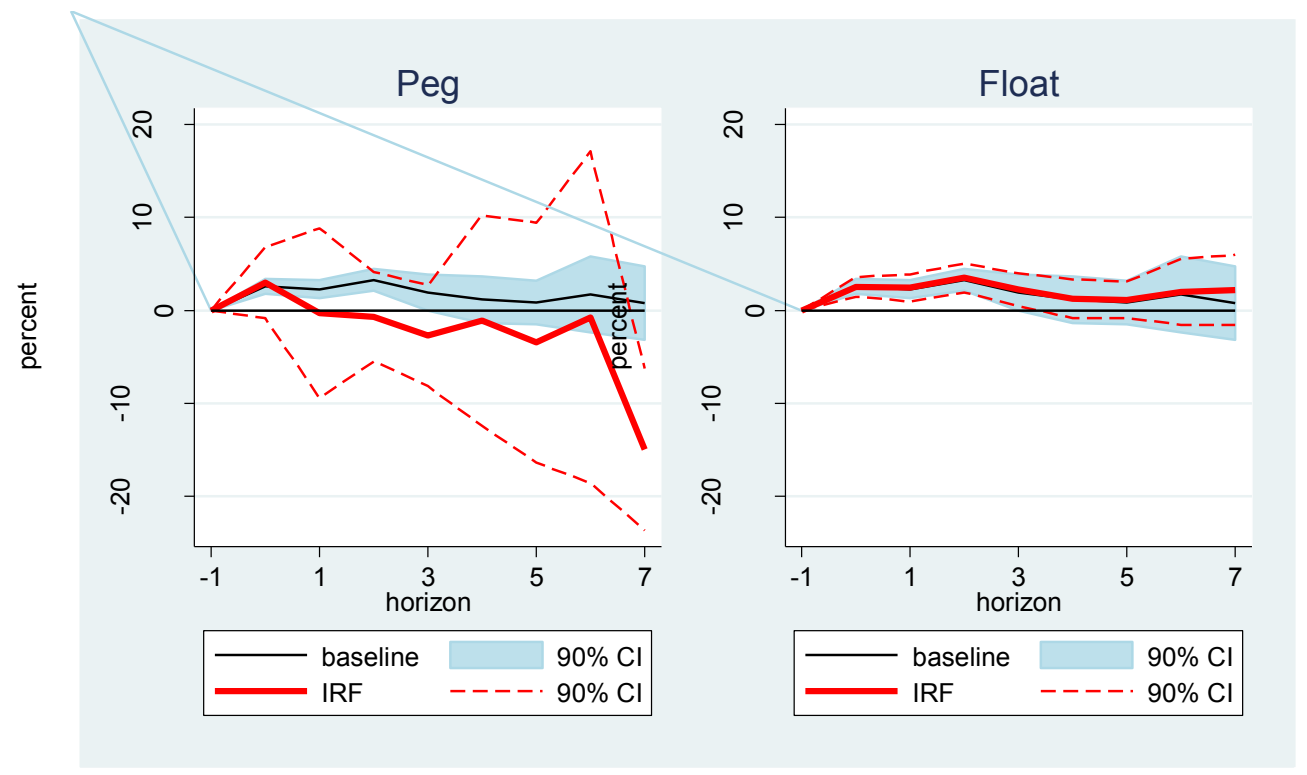

Note: The left (right) panel shows the response of cross-border bank lending to exogenous government spending shocks from Ramey and Zubairy (2018) when the recipient country is pegged (non-pegged). Horizon $h=0$ captures the impact of the shock, and the units are in percentage.

Figure 13. Estimated effect of a U.S. expansionary fiscal policy shock (1 percent of GDP) on crossborder bank lending: financially open vs. closed recipient countries
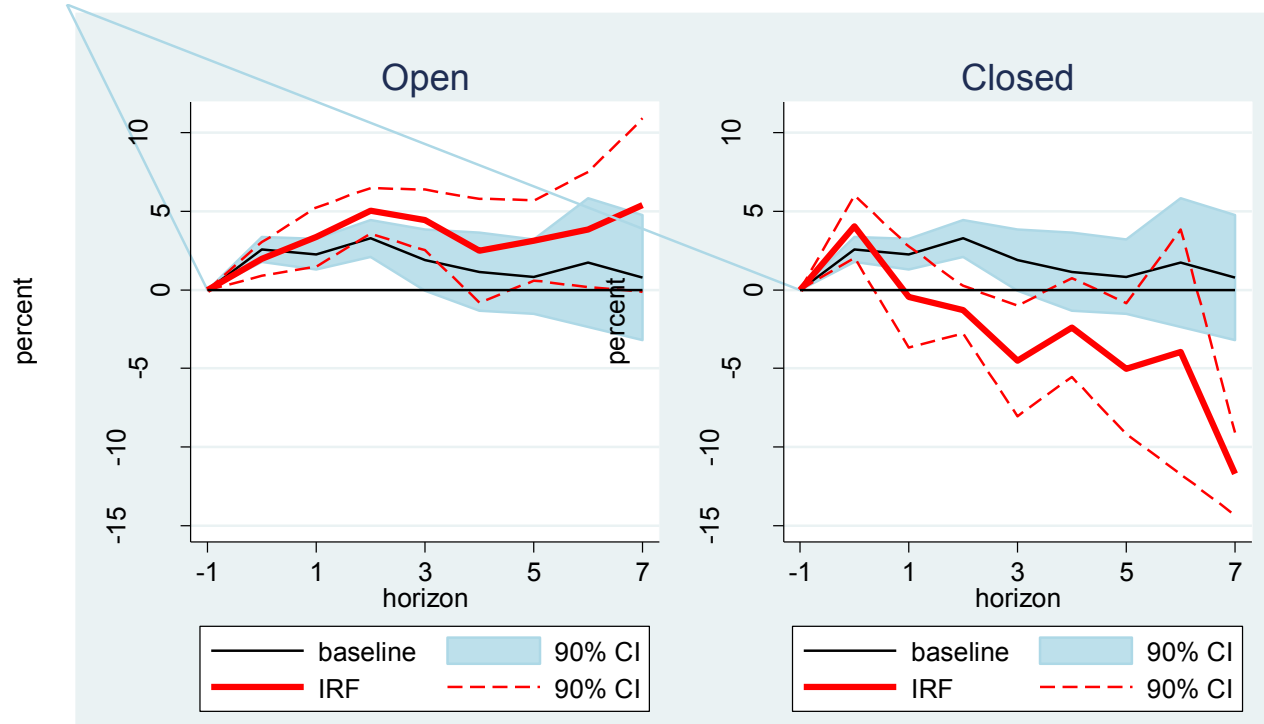

Note: The left (right) panel shows the response of cross-border bank lending to exogenous government spending shocks from Ramey and Zubairy (2018) when the recipient country is financially open (closed). Horizon $h=0$ captures the impact of the shock, and the units are in percentage. 
Figure 14. Distribution of fiscal policy shock as a share of GDP in 16 OECD countries from 1990 and 2010

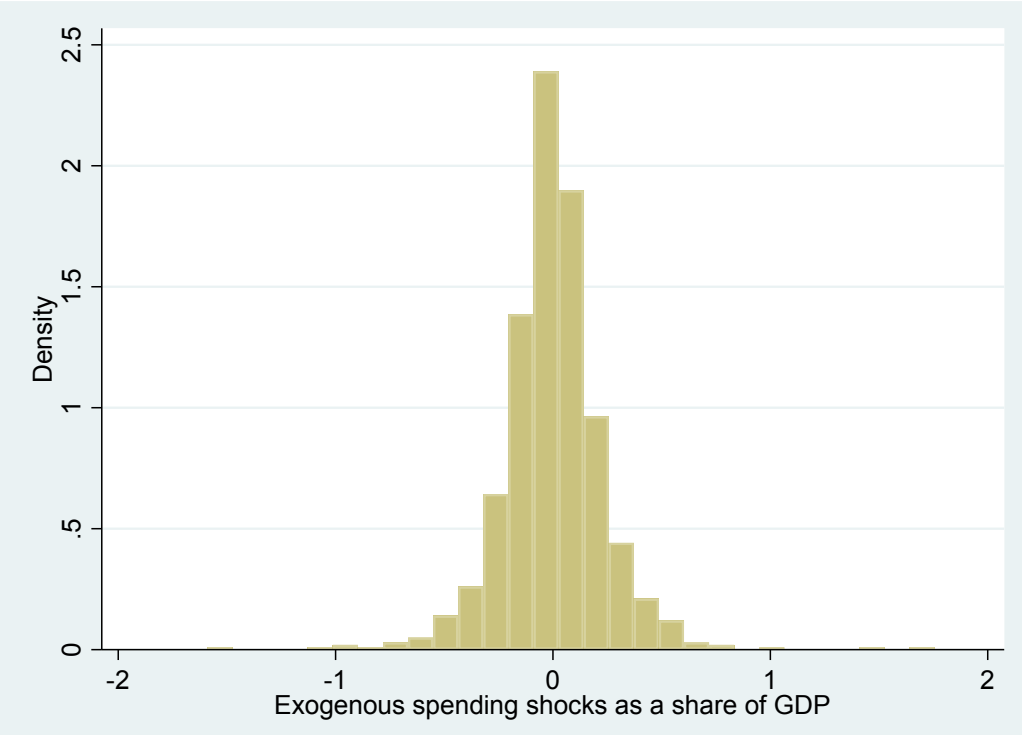

Note: The graph shows the distribution of exogenous government spending shocks normalized by the lagged nominal GDP in 16 OECD countries from Auerbach and Gorodnichencko (2012b).

Figure 15. Estimated effect of expansionary spending shock (1 percent of GDP) on cross-border bank lending using 16 OECD countries

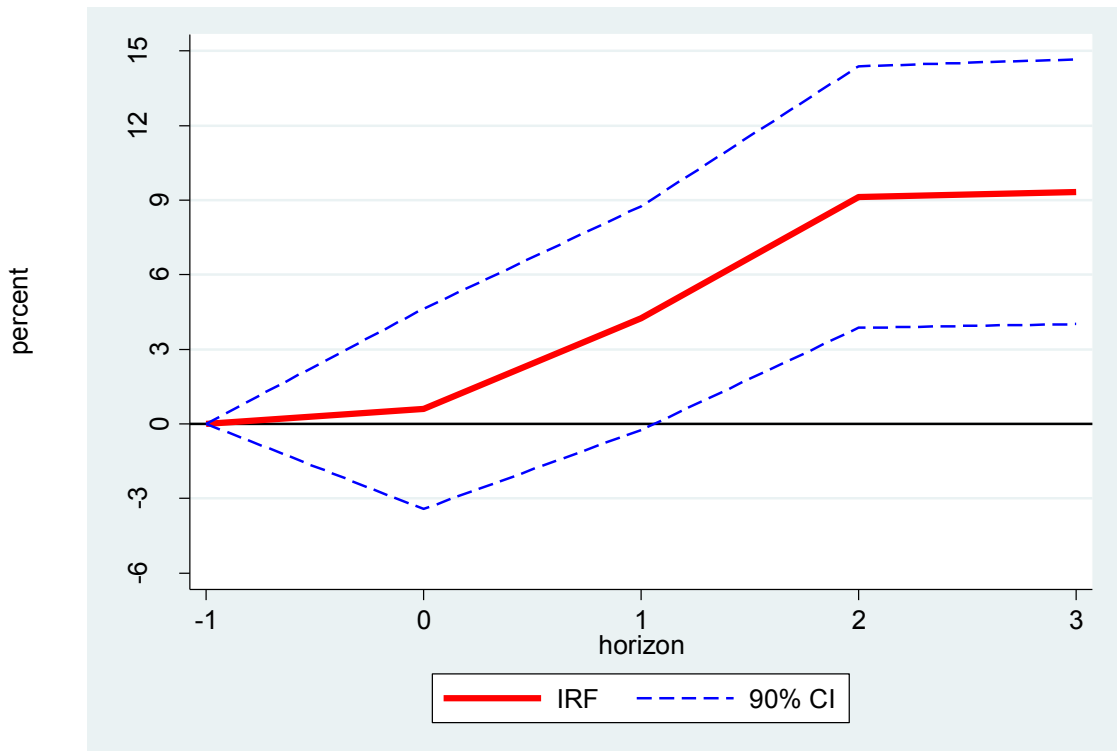

Note: The graph shows the response of cross-border bank lending to exogenous government spending shocks from Auerbach and Gorodnichencko (2012b). Horizon $h=0$ captures the impact of the shock, and the units are in percentage. 


\section{Appendix A. Additional Figures and Tables}

Table A.1. Data availability on cross-border flows in the BIS International Banking Statistics

\begin{tabular}{lccc}
\hline & $\begin{array}{c}\text { Nationality of } \\
\text { lending bank }\end{array}$ & $\begin{array}{c}\text { Residence of } \\
\text { borrowers }\end{array}$ & $\begin{array}{c}\text { Currency } \\
\text { composition }\end{array}$ \\
\hline $\begin{array}{l}\text { Consolidated banking statistics } \\
\text { Locational banking statistics }\end{array}$ & Yes & Yes & No \\
by residence & No & Yes & Yes \\
by nationality & Yes & No & Yes \\
stage 1 data & Yes & Yes & Yes \\
\hline
\end{tabular}

Note: This table is reproduced from Table 1 in Avdjiev and Takáts (2014). In addition to exchange rate fluctuations, the quarterly flows in the locational datasets are corrected for breaks in the reporting population. The BIS consolidated banking statistics group claims according to the nationality of banks (i.e., according to the location of banks' headquarters), netting out inter-office positions. The BIS locational banking statistics define creditors and debtors according to their residence, consistently with national accounts and balance of payments principles. The Stage 1 enhanced data are the first consistent data set to provide all three dimensions at the same time, but the construction of comprehensive time series data is still in progress. 


\section{Appendix B. Robustness Checks}

Figure B.1. Estimated effect of a U.S. expansionary fiscal policy shock (1 percent of GDP) on crossborder bank lending: controlling for other macroeconomic variables
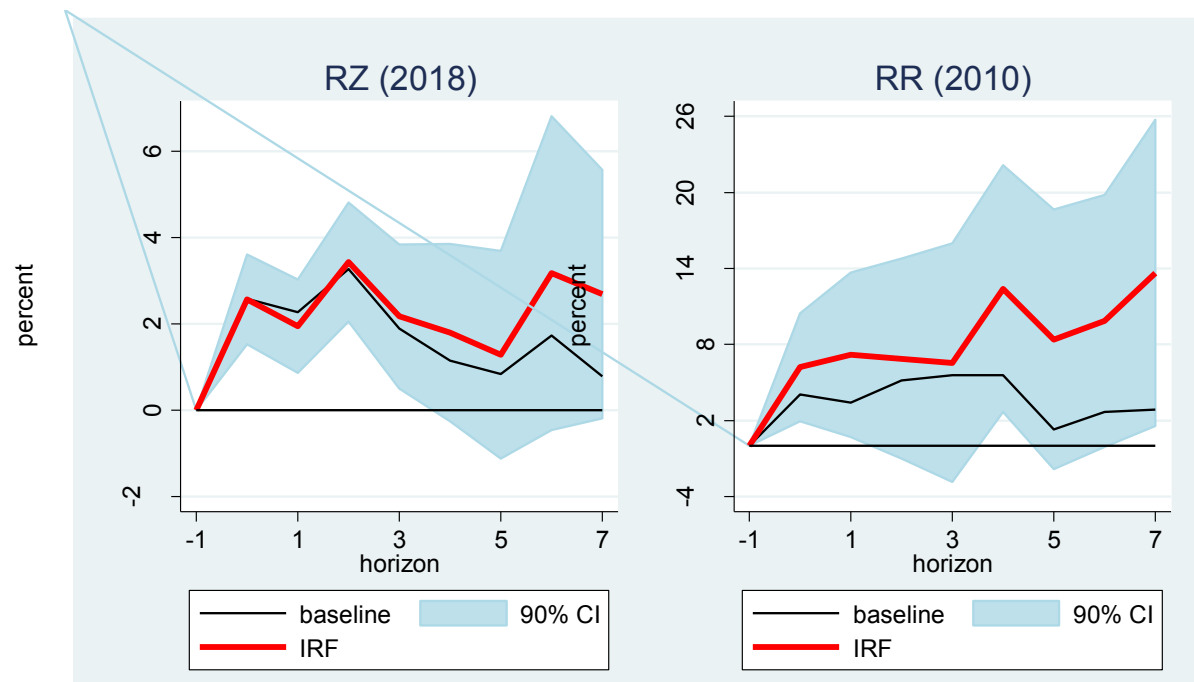

Note: The left panel shows the response of cross-border bank lending to a U.S. expansionary fiscal policy shock ( 1 percent of GDP) using exogenous government spending shocks from Ramey and Zubairy (2018), while the right panel shows the response to exogenous tax shocks from Romer and Romer (2010). Horizon $h=0$ captures the impact of the shock, and the units are in percentage.

Figure B.2. Estimated effect of a U.S. expansionary fiscal policy shock (1 percent of GDP) on crossborder bank lending: using eight lags instead
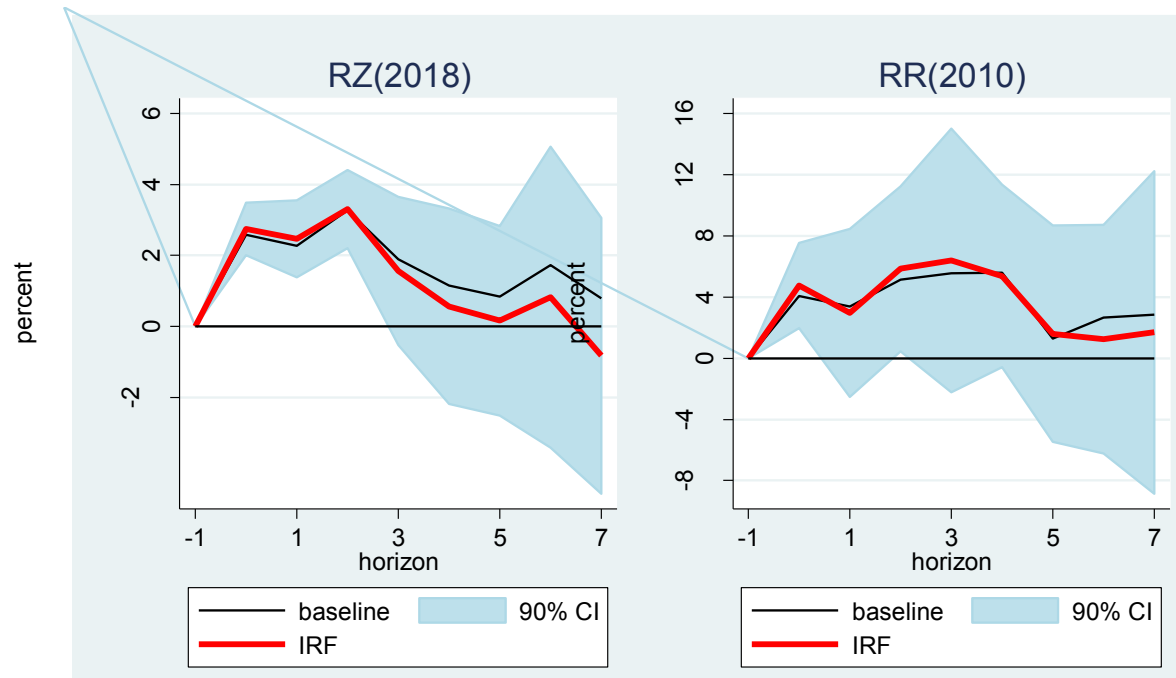

Note: The left panel shows the response of cross-border bank lending to a U.S. expansionary fiscal policy shock (1 percent of GDP) using exogenous government spending shocks from Ramey and Zubairy (2018), while the right panel shows the response to exogenous tax shocks from Romer and Romer (2010). Horizon $h=0$ captures the impact of the shock, and the units are in percentage. Eight lags of dependent and control variables are used in the estimation. 
Figure B.3. Estimated effect of a U.S. expansionary fiscal policy shock (1 percent of GDP) on crossborder bank lending: using Driscoll-Kraay standard error

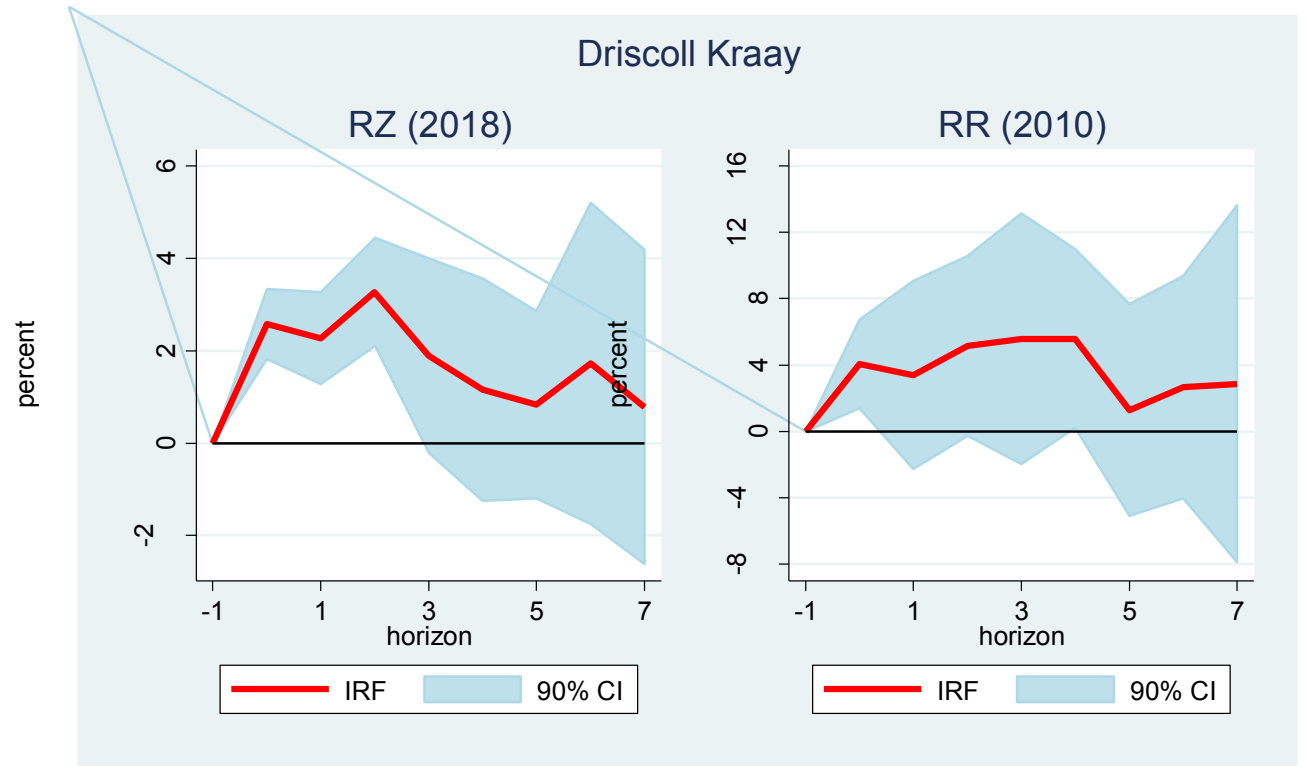

Note: The left panel shows the response of cross-border bank lending to a U.S. expansionary fiscal policy shock (1 percent of GDP) using exogenous government spending shocks from Ramey and Zubairy (2018), while the right panel shows the response to exogenous tax shocks from Romer and Romer (2010). Horizon $h=0$ captures the impact of the shock, and the units are in percentage. Driscoll-Kraay standard errors are used to construct confidence intervals.

Figure B.4. Estimated effect of a U.S. expansionary fiscal policy shock (1 percent of GDP) on crossborder bank lending: controlling for bilateral imports
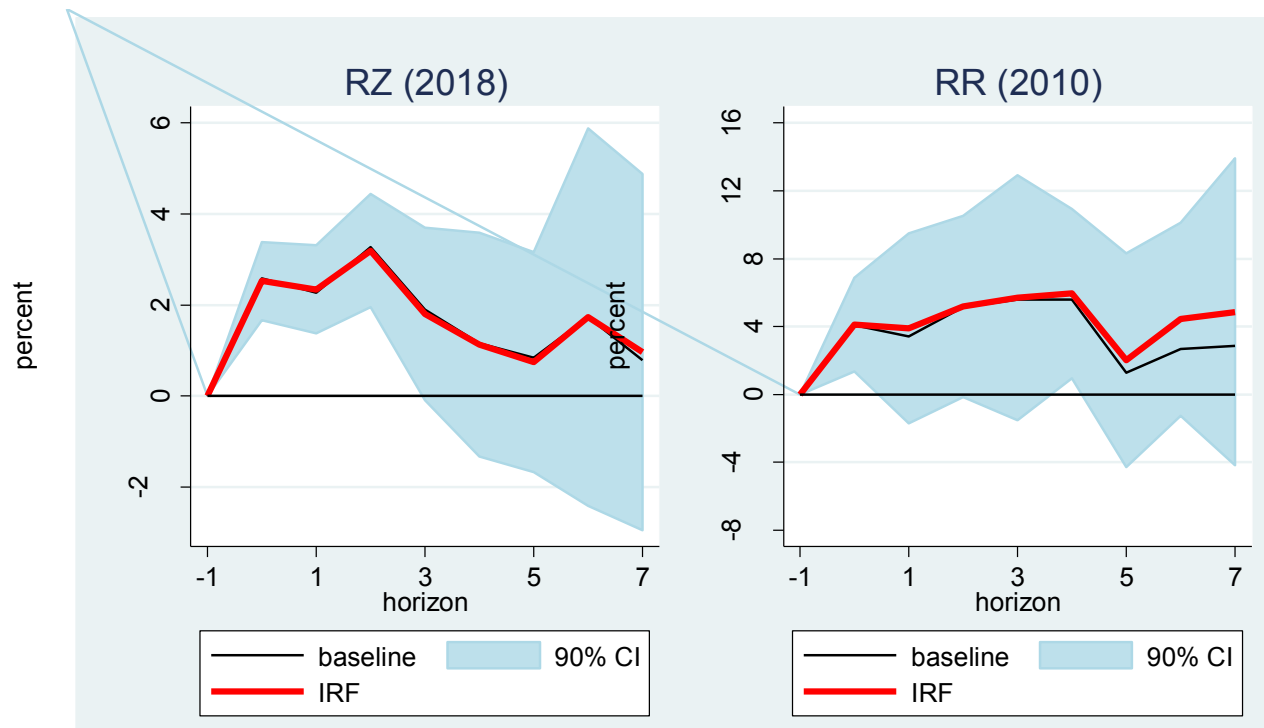

Note: The left panel shows the response of cross-border bank lending to a U.S. expansionary fiscal policy shock (1 percent of GDP) using exogenous government spending shocks from Ramey and Zubairy (2018), while the right panel shows the response to exogenous tax shocks from Romer and Romer (2010). Horizon $h=0$ captures the impact of the shock, and the units are in percentage. 
Figure B.5. Estimated effect of a U.S. monetary policy shock on cross-border bank lending
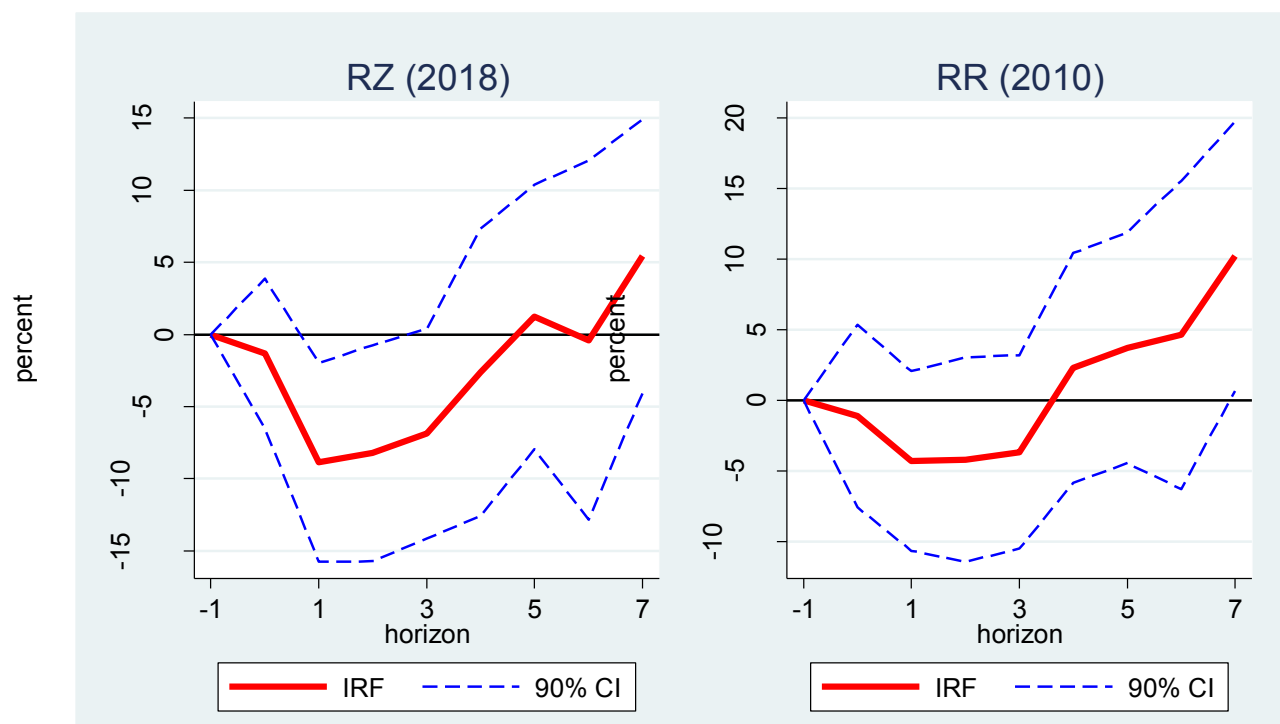

Note: The both panels show the response of cross-border bank lending to a U.S. monetary policy shock constructed by Coibion (2012) who extends the narrative approach by Romer and Romer (2004) when estimated together with RZ's spending shocks (left) and RR's revenue shocks (right). Horizon $h=0$ captures the impact of the shock, and the units are in percentage.

Figure B.6. Estimated effect of a U.S. expansionary fiscal policy shock (1 percent of GDP) on crossborder bank lending after controlling for monetary policy shocks and VIX shocks

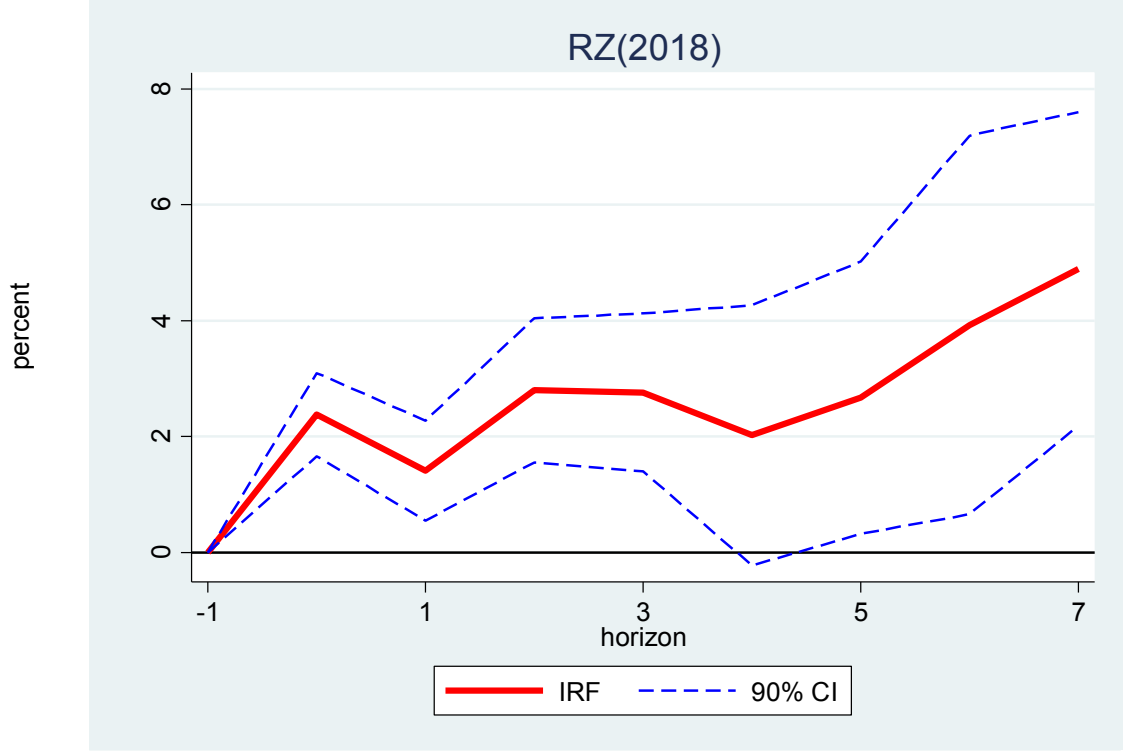

Note: The chart shows the response of cross-border bank lending to a U.S. Fiscal shocks, controlling for monetary policy shocks and VIX. Horizon $h=0$ captures the impact of the shock, and the units are in percentage. 
Figure B.7. Estimated effect of a U.S. expansionary fiscal policy shock (1 percent of GDP) on crossborder bank borrowing
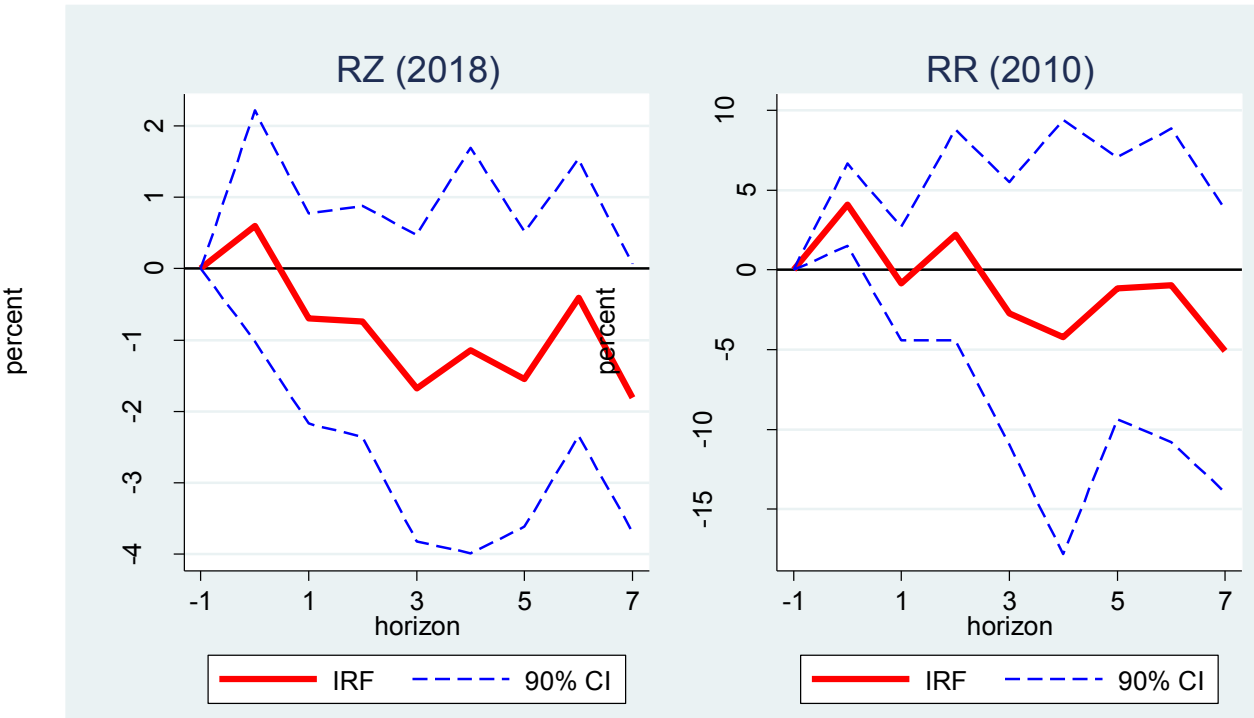

Note: The left panel shows the response of cross-border bank borrowing to a U.S. expansionary fiscal policy shock (1 percent of GDP) using exogenous government spending shocks from Ramey and Zubairy (2018), while the right panel shows the response to exogenous tax shocks from Romer and Romer (2010). Horizon $h=0$ captures the impact of the shock, and the units are in percentage.

Figure B.8. Estimated effect of a U.S. expansionary fiscal policy shock (1 percent of GDP) on crossborder bank lending: advanced vs. emerging market recipient countries
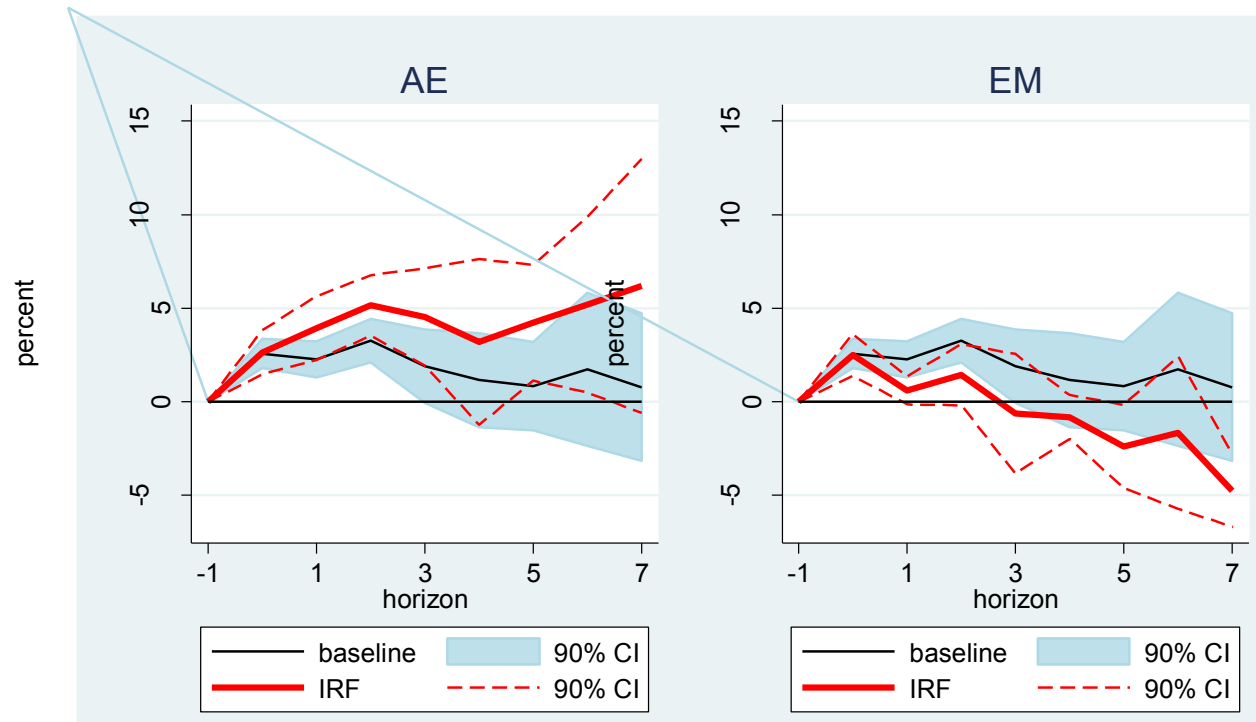

Note: The left (right) panel shows the response of cross-border bank lending to exogenous government spending shocks from Ramey and Zubairy (2018) when the recipient country is an advanced (emerging market) economy. Horizon $h=0$ captures the impact of the shock, and the units are in percentage. 
Figure B.9. Estimated effect of expansionary spending shock (1 percent of GDP) on cross-border bank lending using 16 OECD countries: alternative fixed effects
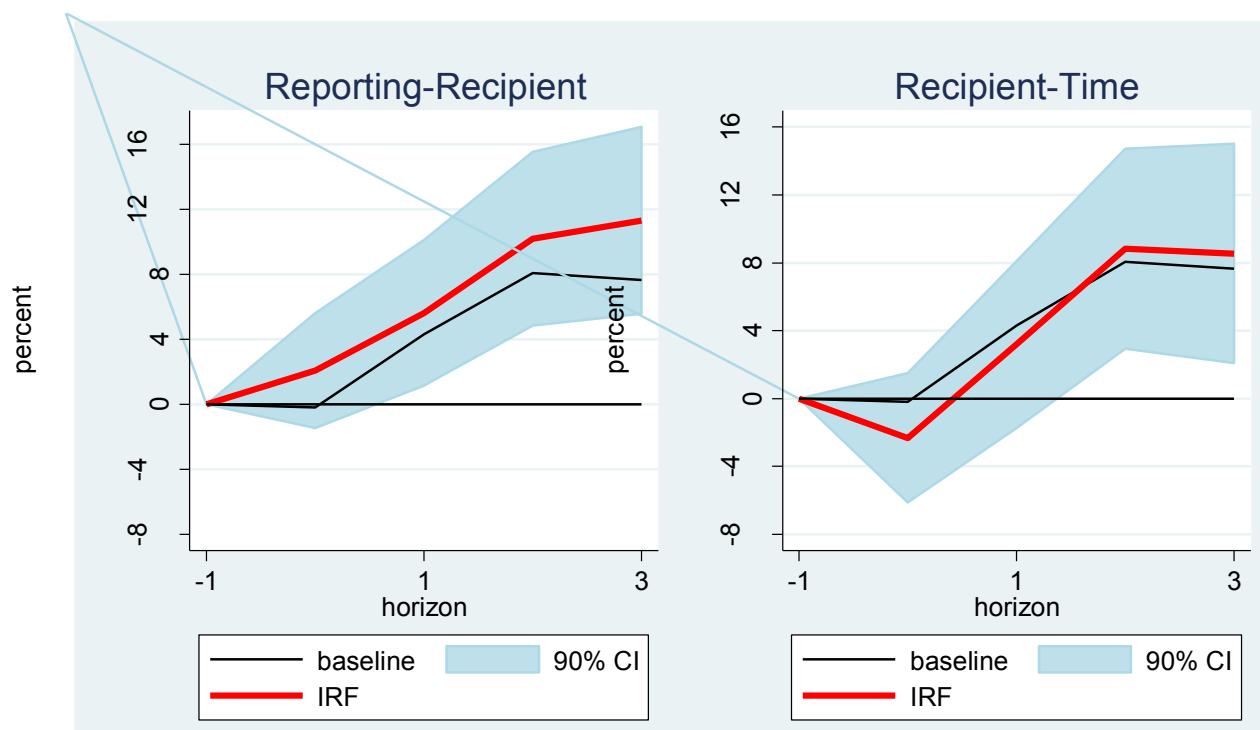

Note: The graph shows the response of cross-border bank lending to exogenous government spending shocks from Auerbach and Gorodnichencko (2012b). Horizon $h=0$ captures the impact of the shock, and the units are in percentage.

Figure B.10. Estimated effect of expansionary fiscal policy shock (1 percent of GDP) on cross-border bank lending using 16 OECD countries: expansions vs. recessions
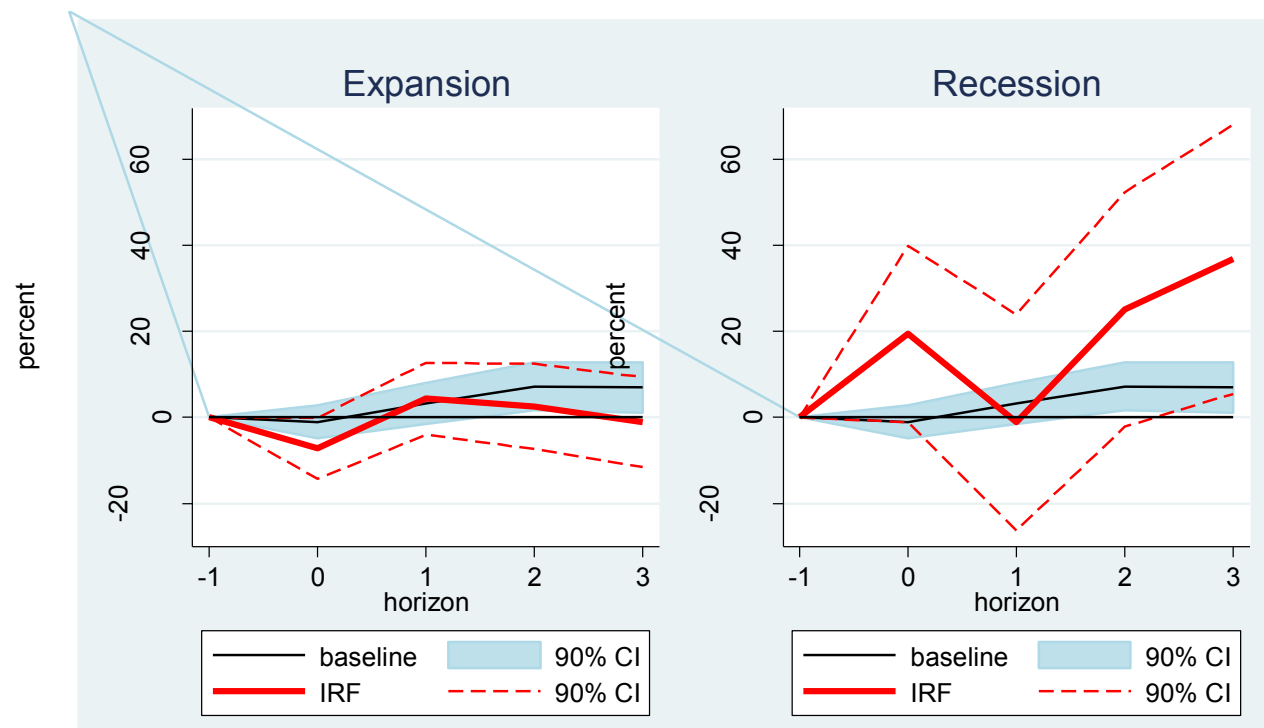

Note: The left (right) panel shows the response of cross-border bank lending to exogenous government spending shocks from Auerbach and Gorodnichencko (2012b) during expansions (recessions). Horizon $h=0$ captures the impact of the shock, and the units are in percentage. 
Figure B.11. Estimated effect of expansionary fiscal policy shock (1 percent of GDP) on crossborder bank lending using 16 OECD countries: expansionary vs. contractionary shocks
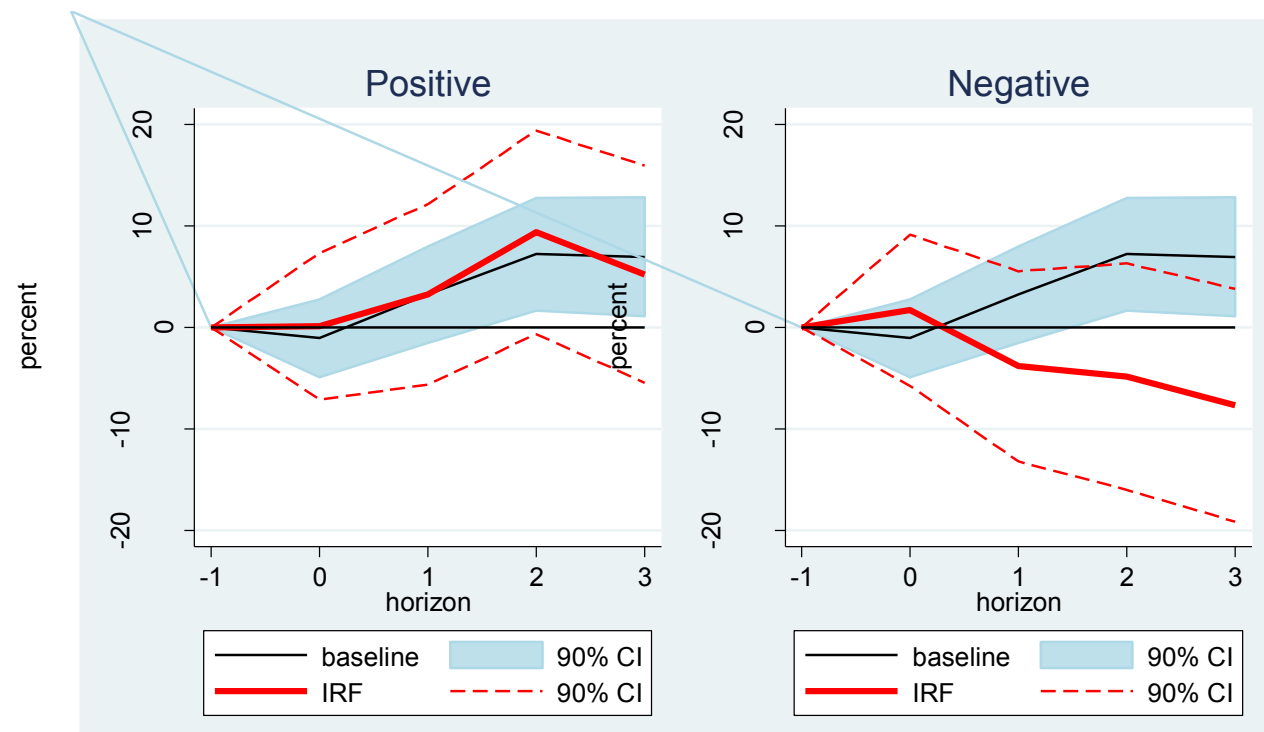

Note: The left (right) panel shows the response of cross-border bank lending to expansionary (contractionary) exogenous government spending shocks from Auerbach and Gorodnichencko (2012b). Horizon $h=0$ captures the impact of the shock, and the units are in percentage. The sign of the response to contractionary shocks is adjusted so that the response is negative in this case.

Figure B.12. Estimated effect of expansionary fiscal policy shock (1 percent of GDP) on crossborder bank lending using 16 OECD countries: pegged vs. non-pegged
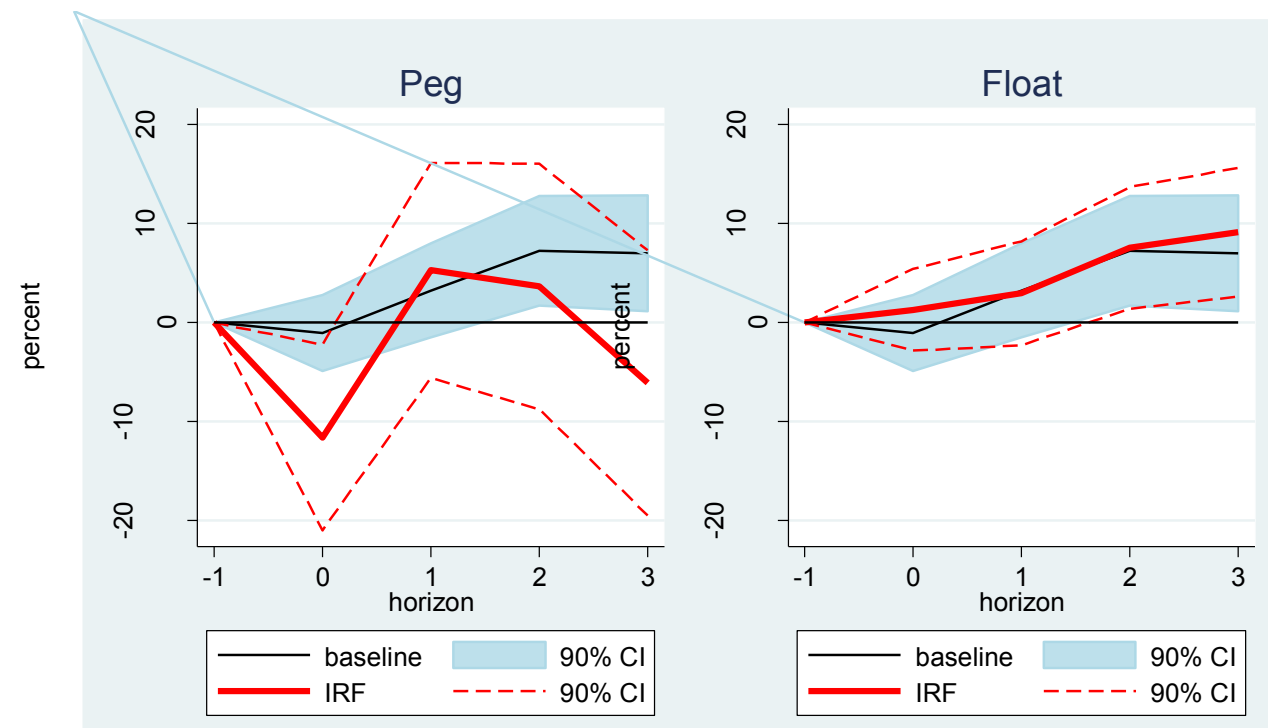

Note: The left (right) panel shows the response of cross-border bank lending to exogenous government spending shocks from Auerbach and Gorodnichencko (2012b) when the recipient country is pegged (non-pegged). Horizon $h=0$ captures the impact of the shock, and the units are in percentage. 
Figure B.13. Estimated effect of expansionary fiscal policy shock (1 percent of GDP) on crossborder bank lending using 16 OECD countries: open vs. closed recipient countries
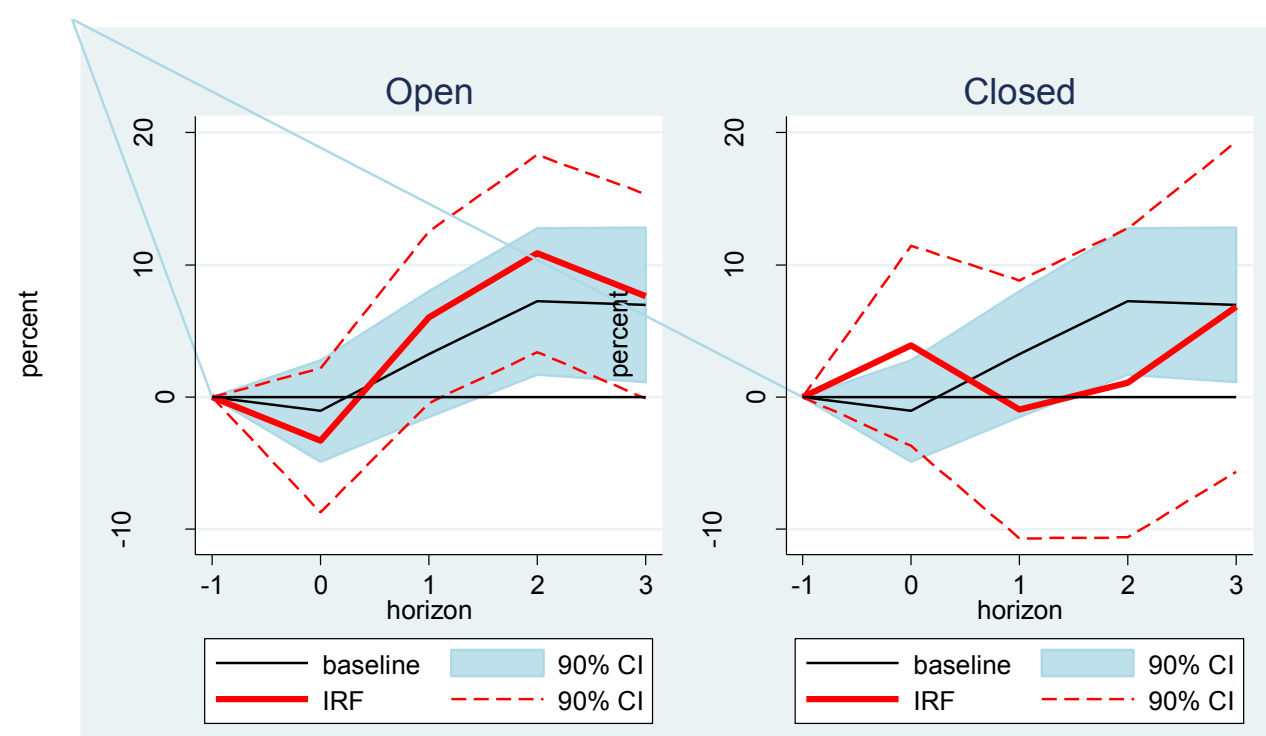

Note: The left (right) panel shows the response of cross-border bank lending to exogenous government spending shocks from Auerbach and Gorodnichencko (2012b) when the recipient country is financially open (closed). Horizon $h=0$ captures the impact of the shock, and the units are in percentage. 